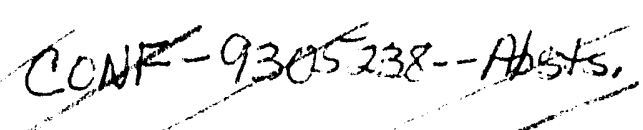

- NREL/CP-420-5466

DE93010005

\title{
RECEIVED
}

\section{JUL 219993}

\section{Fifteenth Symposium on} Biotechnology for Fuels and Chemicals

\section{Program and Abstracts}

\section{The Antlers Doubletree Hotel Colorado Springs, Colorado, USA May 10 14, 1993}

\section{OSTI}

Sponsors

U.S. Department of Energy Office of Alternative fuels Office of hdustrial Processes Office of Transportation Materials National Renewable Energy Laboratory Oak Ridge National Laboratohy A.E. Staley Company Archer Daniels Midland Compary BioEnergy international, L.C. BioTechnical Resources, Inc. Colorado Institute for Research in Biotechnology Genencor internationa!, Inc. Grain Processing Corporation New Energy Company of Indiana Raphael Katzen Associates International, Inc: South Point Ethariol Woyerhacuser Company Michigan Biotechnology Institure American Chemical Society Division of Biochemigal Technology 
NREL/CP-120-5466

DE93010005

NOTICE: This report was prepared as an account of work sponsored by an agency of the United States government. Neither the United States government nor any agency thereof, nor any of their employees, makes any warranty, express or implied, or assumes any legal liability or responsibility for the accuracy, completeness, or usefulness of any information, apparatus, product, or process disclosed, or represents that its use would not infringe priva tely owned rights. Reference herein to any specific commercial product, process, or service by trade name, trademark, manufacturer, or otherwise does not necessarily constitute or imply its endorsement, recommendation, or favoring by the United States government or any agency thereof. The views and opinions of authors expressed herein do not necessarily state or reflect those of the United States government or any agency thereof. 


\section{Symposium Committee \\ Charles Wyman, General Chairman \\ National Renewable Energy Laboratory \\ Golden, Colorado \\ Jonathan Woodward, Co-Chairman \\ Oak Ridge National Laboratory \\ Oak Ridge, Tennessee}

\author{
David Boron \\ U.S. Department of Energy \\ Washington, D.C. \\ James Doncheck \\ Bio-Technical Resources, Inc. \\ Manitowoc, Wisconsin \\ Elias Greenbaum \\ Oak Ridge National Laboratory \\ Oak Ridge, Tennessee \\ Michael Himmel \\ National Renew ble Energy \\ Laboratory \\ Golden, Colorado \\ Tom Jefferies \\ Forest Products Laboratory \\ Madison, Wisconsin
}

Donald Johnson

Grain Processing Corporation

Muscatine, Iowa

Raphael Katzen

Raphael Katzen Associates

International

Cincinnati, Ohio

Hugh Lawford

University of Toronto

Toronto, Ontario

Lee Lynd

Dartmouth College

Hanover, New Hampshire

Richard Moorer

U.S. Department of Energy

Washington, D.C. 
Prepared by the

National Renewable Energy Laboratory

Golden, Colorado 80401-3393

operated by

Midwest Research Institute

for the

U.S. Department of Energy

under contract

DE-AC02-83CH10093 


\section{Program}

Charles E. Wyman

Voice: (303) 231-1753

Fax: (303) 231-1352

6:00 - 10:00 p.m.

7:00 - 10:00 p.m.

8:00 a.m. - 5:00 p.m. Registration

9:00 Guest program (Cameron)

10:00 Tour of the Miramount

Castle (Guest Program)

8:20 Welcome and Introduction to the Symposium, (Heritage A,B, C)

Charles E. Wyman, National Renewable Energy Laboratory, Golden, Colorado

Session 1. Thermal, Chemical, and Biological Processing.

Chair: Michael R. Ladisch, Purdue University, West Lafay^4te, Indiana;

Co-Chair: Graham F. Andrews, Idaho National Engineerii 'ó Laboratory, Idaho Falls, Idaho

8:30 Introduction and Session Overview

8:45 Paper 1. "Two-Temperature Dilute-Acid Prehydrolysis of Hardwood Xylan Using a

Percolation Process," R. Torget and T. Hsu, National Renewable Energy Laboratory,

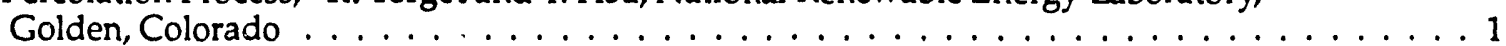

9:10 Paper 2. "Effects of the Dilute Acid and Steam Explosion Pretreatments on the Cellulose Structure and the Kinetics of the Cellulosic Fraction Hydrolysis by Dilute Acids of Different Lignocellulosic Materials," J. E. Carrasco, J. M. Martinez, M. C. Saiz de Bustemente, and F. Saez, Centro de Desarrollo de Energias Renovables, Madrid, Spain . . . . . . . . . . . . . 2

9:35 Paper 3. "Effect of Pretreatment and Post-Treatment on Fermentation of Molasses," S. Inamdar, PRAJ Conseltech PVT. LTD., Pune, India $\ldots \ldots \ldots \ldots \ldots \ldots$

10:00 Paper 4. "Determination of Reaction Kinetics of Barley Straw Using Thermogravimetric Analysis," A. E. Ghaly and A. Ergudenler, Technical University of Nova Scotia, Halifax, Nova Scotia, Canada . . . . . . . . . . . . . . . . . . . . 5

10:25 Intermission

10:45 Paper 5. "Ethanol Fermentation of AFEX-Treated Switchgrass by Genetically-Engineered Klebsiella oxytoca," S. Reshamwala, B. T. Shawky, V. M. Latimer, and B. E. Dale, Texas A\&M University, College Station, Texas . . . . . . . . . . . . . . . . . . 6

11:10 Paper 6. "Influence of Storage Conditions on the Production of Liquid Fuels from Herbaceous Biomass," F. A. Agblevor, D. Wang, B. Rejai, A. Wiselogel, and H. L. Chum, National Renewable Energy Laboratory, Golden, Colorado $\ldots \ldots \ldots \ldots \ldots \ldots$

11:35 Paper 7. "Selective Dehydration of Glucose to Organic Acids in Microporous Pillared-Clay Catalysts," K. Lourvanij and G. L. Rorrer, Oregon State University, Corvallis, Oregon . . . . 8

Noon Session Adjournment 


\section{Tuesday Afternoon, May 11, 1993}

Session 2. Applied Biological Research. (Heritage A, B, C)

Chair: Jack N. Saddler, University of British Columbia, Vancouver, British Columbia, Canada;

Co-Chair: Shih-Perng Tsai, Argonne National Laboratory, Argonne, Illinois

1:30 Introduction and Session Overview

1:45 Paper 8. "The Use of Enzyme Recycle During Hydrolysis of Pretreated Cellulose,"

L. P. Ramos and J. N. Saddler, University of British Columbia, Vancouver, British Columbia,

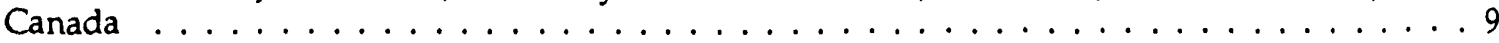

2:10 Paper 9. "Endoglucanase E1 from Acidothermus cellulolyticus is a Family A Cellulase," S. R. Thomas, R. A. Laymon, M. P. Tucker, T. B. Vinzant, W. S. Adney, R. A. Nieves, J. O. Baker, and M. E. Himmel, National Renewable Energy Laboratory, Golden, Colorado . . . . . . . . 10

2:35 Paper 10. "Enhancement of the Hydrolytic Activity of Cellobiohydrolase I by the Covalent Attachment of Pentaamine Ruthenium," B. R. Evans and J. Woodward, Oak Ridge National Laboratory, Oak Ridge, Tennessee; R. M. Margalit, Jet Propulsion Laboratory, Pasadena,

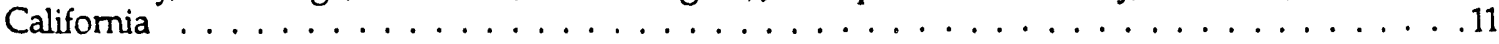

3:00 Intermission

3:20 Paper 11. "Organism Development and Characterization for Ethanol Production Using Thermophilic Bacteria," T. R. Klapatch, D. A. Hogsett, S. Baskaran, S. Pal, and L. R. Lynd, Dartmouth College, Hanover, New Hampshire . . . . . . . . . . . . . . . . . . . . . .12

3:45 Paper 12. "Stimulatory Effect of Red Light on Starch Accumulation in Marine Green Alga, Chlamydomonas sp. MGA 161," K. Yagi, K. Hamada, K. Hirata, K. Miyamoto, and Y. Miura, Osaka University, Osaka, Japan; T. Akano and K. Fukatu, Kansai Electric Power Company, Inc., Osaka, Japan; Y. Ikuta and H. K. Nakamura, Mitsubishi Heavy Industries, Ltd., Osaka,

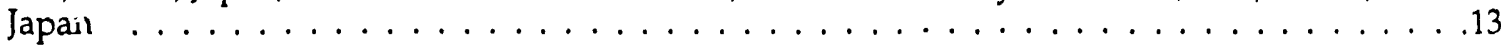

4:10 Paper 13. "Biochemistry of Microbially Mediated Organic Sulfur Removal," J. R. Gallagher, E. S. Olson, and D. C. Stanley, University of North Dakota, Grand Forks, North Dakota . . . . 14

4:35 Paper 14. "Cell Separations Using Targeted Monoclonal Antibodies Against Overproduced Surface Proteins," K. Tadikonda and R. H. Davis, University of Colorado, Boulder, Colorado . .15

5:00 Session Adjournment

\section{Tuesday Evening, May 11, 1993}

6:30 Social Hour (Summit Foyer)

7:30 Banquet (Summit Ballroom)

8:30 After-dinner address: "Wit and Wisdom of Politics," Chuck Henning

\section{Wednesday Morning, May 12, 1993}

8:00 a.m. - Noon Registration

9:00 Guest Program (Cameron)

10:00 Seven Falls Tour (Guest Program)

Session 3. Bioprocessing Research. (Heritage A, B, C)

Chair: Rakesh K. Bajpai, University of Missouri Culumbia, Columbia, Missouri;

Co-Chair: Barbara J. Goodman, National Renewable Energy Laboratory, Golden, Colorado 
8:45 Paper 15. "An Advanced Bioprocessing Concept for the Conversion of Wastepaper to Ethanol," C. D. Scott, B. H. Davison, B. D. Faison, T. C. Scott, and J. Woodward, Oak Ridge National Laboratory, Oak Ridge, Tennessee . . . . . . . . . . . . . . . . . . . . 16

9:15 Paper 16. "Biochemical Conversion of Cellulosic Biomass to Fuel Ethanol in the Continuous Operational Mode," G. P. Philippidis, T. K. Smith, and C. E. Wyman, National Renewable Energy Laboratory, Golden, Colorado . . . . . . . . . . . . . . . . . . . . . 17

9:45 Paper 17. "Bioreactors for Conversion of Particulate Biomass to Ethanol: Experimental Results, Analysis, and Design," C. R. South, D. A. Hogsett, and L. R. Lynd, Dartmouth College, Hanover, New Hampshire . . . . . . . . . . . . . . . . . . . . . . . . 18

10:15 Intermission

10:30 Paper 18. "Integrated Production of Ethanol Fuel and Protein from Coastal Bermudagrass," L. B. de la Rosa, V. M. Latimer, S. Reshamwala, and B. E. Dale, Texas A\&M University, College Station, Texas . . . . . . . . . . . . . . . . . . . . . . 19

11:00 Paper 19. "One-Step Photoconversion of Biomass to Volatile Hydrocarbons and Molecular Oxygen," E. Greenbaum, C. V. Tevault, and C. Y. Ma, Oak Ridge National Laboratory, Oak Ridge, Tennessee . . . . . . . . . . . . . . . . . . . . . . . . . . 20

11:30 Paper 20. "Extractive Recovery of Products from Fermentation Broths," Y.-T. Su, J. Kim, E. L. Iannotti, and R. K. Bajpai, University of Missouri-Columbia, Columbia, Missouri . . . . .21

Noon Session Adjournment

Wine tasting and luncheon buffet (Heritage D,E, F)

Wednesday Aftemoon, May 12, 1993

12:45 Pikes Peak Cog Railroad Tour

1:15 Tour of National Renewable Energy Laboratory

Wednesday Evening, May 12, 1993

7:00 - 9:00 p.m.

Special Topic Discussion Groups

"Stability of Genetically Engineered Microorganisms," Mark Finkelstein, National Renewable Energy Laboratory, Golden, Colorado (Heritage A, B)

"Algal Biotechnology for Fuels and Chemicals," Gregory Rorrer, Oregon State University, Corvallis, Oregon (Heritage C)

\section{Thursday Morning, May 13, 1993}

8:00 a.m. - Noon Registration

9:00 Guest program (Cameron)

10:00 Old Colorado City \& Van Briggle Pottery Tour (Guest Program)

Session 4. Process Economics and Commercialization. (Heritage A, B, C)

Chair: Donald L. Johnson, Grain Processing Corporation, Muscatine, Iowa;

Co-Chair: Lawrence J. Russo, New Energy Company of Indiana, South Bend, Indiana

8:30 Introduction and Session Overview

8:45 Paper 21. "Methodology for Evaluating the Economics of Biologically Producing Chemicals and Materials from Alternative Feedstocks," R. Landucci, B. J. Goodman, and C. E. Wyman, National Renewable Energy Laboratory, Golden, Colorado . . . . . . . . . . . . . . . .22 
9:10 Paper 22. "Design of a Commercial Municipal Solid Waste to Ethanol Facility Using a OneStage Dilute Sulfuric Acid Hydrolysis Process," T. M. Shipley, M. M. Bulls, J. D. Broder,

R. O. Lambert Jr., and J. W. Barrier, Ternessee Valley Authority, Muscle Shoals, Alabama . . .23

9:35 Paper 23. "Ethanol from Lignocellulosic Wastes with Utilization of Recombinant Bacteria," R. Katzen, Raphael Katzen Associates International, Inc., Cincinnati, Ohio; D. E. Fowler, BioEnergy International, L.C., Gainesville, Florida . . . . . . . . . . . . . . . . . . . . . 24

10:00 Paper 24. "Economics of Molasses to Ethanol in India," S. Inamdar, PRAJ Conseltech PVT.

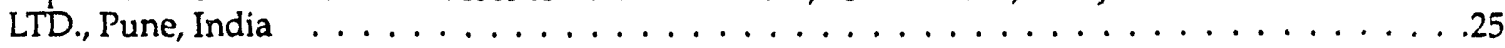

10:25 Intermission

10:45 Paper 25. "Biomass Refineries: Renewable Resources for Production of Advanced Materials, Specialty Chemicals and Fuels," L. D. Clements, U.S. Department of Agriculture,

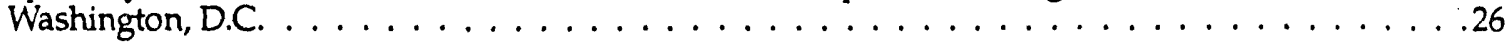

11:10 Paper 26. "Production of 1,4-butanediol from Succinic Acid," W. Walker, John Brown Engineering and Construction, Chicago, Illinois . . . . . . . . . . . . . . . . . . . . . . . .

11:35 Paper 27. "Production of Lactic Acid from Renewable Resources," J.K. Brooks, John Brown Engineering and Construction, Chicago, Illinois $\ldots \ldots \ldots \ldots$

Noon Session Adjournment

\section{Thursday Aftemoon, May 13, 1993}

White Water Rafting (Lunch provided)

$1: 15$

Cripple Creek Tour

\section{Special Topic Discussion Groups}

1:00 - 5:00 p.m. "Low-Cost Materials of Construction for Biological Processes," Cindy Riley, National Renewable Energy Laboratory, Golden, Colorado (Heritage A, B)

2:00 - 4:00 p.m. "Novel Chemicals and Materials from Biomass," Larry Russo, New Energy Company, South Bend, Indiana (Heritage C)

\section{Thursday Evening, May 13, 1993}

6:30 Social Hour (Summit Foyer)

7:00 Poster Session. A tentative list of poster titles is given at the end of this program. Chair: Karel Grohmann, U.S. Citrus and Subtropical Products Research Laboratory, Winter Haven, Florida;

Co-Chair: Antonios Antonopoulos, Argonne National Laboratory, Argonne, Illinois (Summit Ballroom)

Friday Morning, May 14, 1993

8:00 a.m. - Noon

Registration

Session 5. Environmental Biotechnology.

Chair: Jonathan R. Mielenz, COGNIS, Inc., Santa Rosa, California;

Co-Chair: Mark Reeves, Oak Ridge National Laboratory, Oak Ridge, Tennessee

8:30 Introduction and Session Overview

8:45 Paper 28. "Bioluminescent Reporter Bacteria Detect Contaminants in Soil Samples,"

R. S. Burlage and A. V. Palumbo, Oak Ridge National Laboratory, Oak Ridge, Tennessee;

A. Heitzer and G. Sayler, University of Tennessee, Knoxville, Tennessee . . . . . . . . . . . .29 
9:15 Paper 29. "A Field-Scale Demonstration of a Novel Bioremediation Process for MGP Sites," V. J. Srivastava, R. L. Kelley, and J. R. Paterek, Institute of Gas Technology, Chicago, Illinois; T. D. Hayes, Gas Research Institute, Chicago, Illinois; S. Nelson, Midwest Gas Company, Sioux City, Iowa; and J. Golchin, State of Iowa, Ames, Iowa $\ldots \ldots$. . . . . . . . . . . . . .

9:45 Paper 30. "Characterization and Biotreatability of Petroleum Contaminated Soils in a Coral Atoll in the Pacific Ocean," R. L. Siegrist, T. J. Phelps, N. E. Korte, D. A. Pickering, R. Mackowski, and L. W. Cooper, Oak Ridge National Laboratory, Oak Ridge, Tennessee . . . 31

10:15 Intermission

10:30 Paper 31. "Alternating Extraction/Injection Well Interactions for In Situ Bioremediation," M. S. Shouche and J. N. Petersen, Washington State University, Pullman, Washington; R.S. Skeen, Battelle Pacific Northwest Laboratories, Richland, Washington; and B. H. Hooker, Tri-State University, Angola, Indiana . . . . . . . . . . . . . . . . . . . . 32

11:00 Paper 32. "Landfill Management for Methane Generation and Emission Control,"

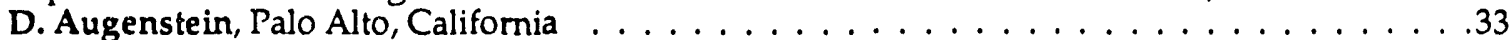

11:30 Paper 33. "Full-Scale Field Test of a Microbial Sulfide Oxidation Process in an Oil Field Sour Water Retention Pond," K. Raterman, Amoco Production Company, Tulsa, Oklahoma;

K. L. Sublette and P. T. Selvaraj, University of Tulsa, Tulsa, Oklahoma . . . . . . . . . . . . 34

Noon Symposium Adjournment 


\title{
Poster Presentations
}

\author{
(Invited to Participate)
}

Poster Session 1. Thermal, Chemical, and Biological Processing

Poster 1 "Critical Reactions in Ripening of Cheeses: A Kinetic Analysis," J. Kim, M. Starzak, G. W. Preckshot, and R. K. Bajpai, University of Missouri-Columbia, Columbia, Missouri . . . .35

Poster 2 "Design and Installation of the NREL Biomass-to-Ethanol Process Development Unit," D. Schell, B. Duff, and P. Bergeron, National Renewable Energy Laboratory, Golden,

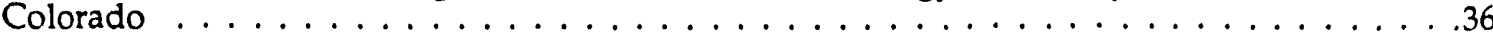

Poster 3 "Field Testing of Indirect Gasification of Biomass for Syngas Production," K. Durai-Swamy and B. Aghamohammadi, MTCI, Inc., Santa Fe Springs, California . . . . . . . . . . . . . . .37

Poster 4 "An Improved Prototype Apparatus and Process for Separating Cellulosic Materials from Municipal Solid Waste," M. H. Eley, The University of Alabama in Huntsville, Huntsville,

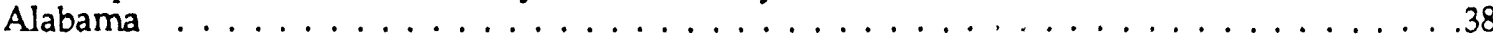

Poster 5 "Microbial Liquefaction of Lignite Pretreated with Dilute Acid at Elevated Temperature and Pressure," H. Huckabay, A. Rao, A. Maxey, and B. B. Elmore, Louisiana Technical University,

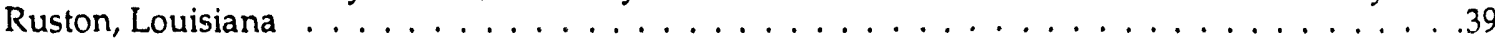

Poster 6 "Buried Oil Recovery with the Help of the Polysaccharide Ethapolan," T. A. Grinberg, S. A. Vlasov, T. P. Pirog, and Y. R. Malashenko, Zabolotny Institute of Microbiology and Virology, Kiev, The Ukraine

Poster 7 "Anaerobic Downflow Stationary Fixed Film Reactor: Early Startup with Dairy Wastewater," N. Mehadia and A. O. Ingle, Nagpur University, Nagpur, India . . . . . . . . . . . . . .

Poster 8 "Fuel and Energy Crisis, Buried Oil, and Microbiology," Y. R. Malashenko, T. A. Grinberg, and S. A. Vlasov, Zabolotny Institute of Microbiology and Virology, Kiev,

Poster 9 "Performance and Emission Characteristics of a Diesel Engine Operating on a Safflower Seed Oil Methyl Ester," A. Isigigur, F. Karaosmanoglu, and H. A. Aksoy, Istanbul Technical

Poster 10 "Methyl Ester from Safflower Seed Oil of Turkish Origin as a Biofuel for Diesel Engines," A. Isigigur, F. Karaosmanoglu, and H. A. Aksoy, Istanbul Technical University, Istanbul,

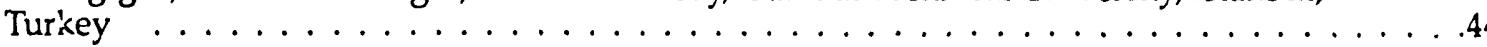

Poster 11 "Simulation of a Modified Percolation Process in Dilute-Acid Hydrolysis of Biphasic Hemicellulose," B. J. Kim and Y. Y. Lee, Aubum University, Auburn, Alabama; R. Torget, National Renewable Energy Laboratory, Golden, Colorado . . . . . . . . . . . . . . . . . . . . .45

Poster 12 "Recovery of Lactic Acid by Adsorption: Resin Evaluation," R. L. Evangelista and Z. L. Nikolov, Iowa State University, Ames, Iowa . . . . . . . . . . . . . . . . . . . . .46

Poster 13 "Synthesis Gas as a Substrate for Biological Fuels and Chemicals Production," J. R. Phillips, E. C. Clausen, and J. L. Gaddy, University of Arkansas, Fayetteville, Arkansas . . . . . . . . . . .47

Poster 14 "Milling of Lignocellulosic Biomass: Results of Pilot Scale Testing," D. Schell, National Renewable Energy Laboratory, Golden, Colorado; C. Harwood, John Brown Engineering and

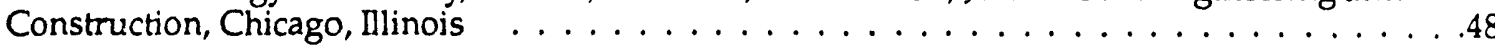

Poster 15 "Wheat as a Feedstock for Fuel Ethanol," K. Sosulski, Saskatchewan Research Council, Saskatoon, Saskatchewan, Canada; F. Sosulski, University of Saskatchewan, Saskatoon,

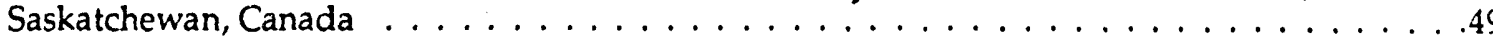

Poster 16 "Bioelectrosynthesis as an Alternative to Photosynthesis," S. D. Varfolomeyev, M. V. Lomonosov Moscow University, Moscow, Russia . . . . . . . . . . . . . . . . . . . . 50 
Poster Session 2. Applied Biological Research

Poster 17 "Synergism Studies of Bacterial and Fungal Cellulases at Low Total Cellulase Loadings,"

J. O. Baker, W. S. Adney, R. A. Nieves, S. R. Thomas, and M. E. Himmel, National Renewable Energy Laboratory, Golden, Colorado; D. B. Wilson, Cornell University, Ithaca, New York . . .51

Poster 18 "Microorganism Inulinase Secretion Using Chemically Modified Inulins," J. D. Fontana, M. Baron, and V. C. Franco, Biomass Chemo/Biotechnology Laboratory, Curitiba, Parana,

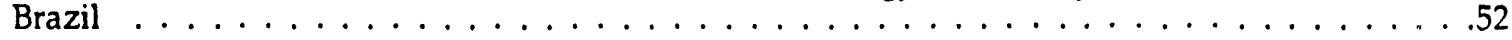

Poster 19 "PCR Protocol and Inulin Catabolism-Based Differentiation of Inulinolytic Soil Bacteria," J. D. Fontana, S. Astolfe Fo., J. Kaiss, M. C. O. Hauly, V. C. Franco, R. Rogelin, and M. Baron, Biomass Chemo/Biotechnology Laboratory, Curitiba, Parana, Brazil . . . . . . . . . . . . .53

Poster 20 "Effect of Media Supplementation on Ethanol Production by the Simultaneous Saccharification and Fermentation Process," I. Ballesteros, J. M. Oliva, J. E. Carrasco, and M. Ballesteros,

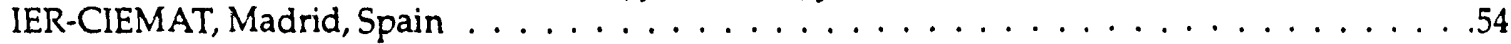

Poster 21 "Xylose - Xylitol: Biohydrogenation by Candida parapsilosis," M. I. Delia-Dupuy, Laboratoire de Génie Chimique, Toulouse-Cedex, France; P. Strehaiano, Laboratoire d'Etude et d'Analyse

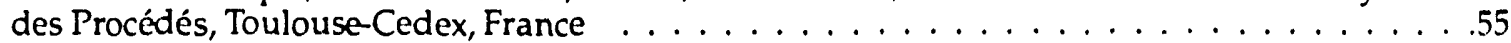

Poster 22 "Selected Strains and Contaminants: A Kinetic Approach," M. L. Delia-Dupuy and J. P. Riba, Laboratoire de Génie Chimique, Toulouse-Cedex, France; N. Ravaz and P. Strehaiano, Laboratoire d'Etude et d'Analyse des Procédés, Toulouse-Cedex, France . . . . . . . . . . . 56

Poster 23 "The Role of the Cellulose-Binding Domain of Trichoderma reesei Cellobiohydrolase I in Cellulose Hydrolysis," T. R. Donner and J. Woodward, Oak Ridge National Laboratory, Oak Ridge,

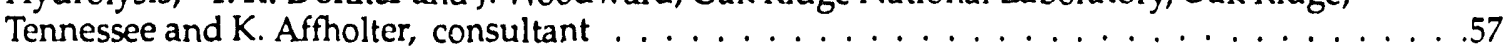

Poster 24 "Conversion of Inulin from Jerusalem Artichokes to Sorbitol and Ethanol by Saccharomyces cerevisiae," Z.D. Duan and G. Turcotte, University of Ottawa, Ottawa, Ontario, and Z. Duvnjak, Université Laval, Cité Universitaire, Québec, Canada . . . . . . . . . . . . . . . 58

Poster 25 "Upgrading of Canola Meal by Reducing its Sinapic Acid Esters Content," K. Lacki and Z. Duvnjak, University of Ottawa, Ottawa, Ontario, Canada . . . . . . . . . . . . . . . . 59

Poster 26 "Production of Phytase and Reduction of Phytic Acid Content in Canola Meal by Aspergillus Carbonarius During a Solid State Fermentation Process," S. Al-Asheh and Z. Duvnjak,

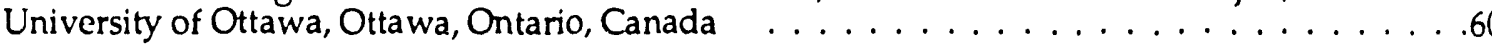

Poster 27 "Screening of Acetogenin-Like Compounds in Brazilian Flora: Annona and Rollinia sp.," J. D. Fontana, M. Baron, F. C. Deschamps, M. F. Guimaraes, F. Zanette, A. C. Cervi, and E. R. A. Almeida, Biomass Chemo/Biotechnology Laboratory, Curitiba, Parana, Brazil

Poster 28 " $\propto$ Xylo- $\beta-$ Glucan Monomerization and Plant Protoplast Release Using the Hydrolase Complex from the Gastric Juice of the Land Snail Megalobulimus," J. D. Fontana, M. Gebara, and I. N. Lyra, Biomass Chemo/Biotechnology Laboratory, Curitiba, Parana, Brazil . . . . . . . . . .62

Poster 29 "Dehydrogenase Activity Measurement in Aerobic Waste Treatment Systems," A. E. Ghaly, Technical University of Nova Scotia, Halifax, Nova Scotia, Canada . . . . . . . . . . . . .63

Poster 30 "New Methods of Improving Hydrogen Yields by Photosynthetic Water Splitting," E. Greenbaum and S. L. Blankinship, Oak Ridge National Laboratory, Oak Ridge, Tennessee; R. M. Cinco, University of California-Berkeley, Berkeley, California . . . . . . . . . . . . . . .64

Poster 31 "Bioconversion of Carbohydrates in Orange Peel to Ethanol," K. Grohmann and E. A. Baldwin, U.S. Citrus and Subtropical Products Research Laboratory, Winter Haven, Florida . . . . . . . .65

Poster 32 "Studies on Directive Screening of High Protein Content Strains of SCP," C. Hongzhang, Shandong Institute of Chemistry, Jinan, China . . . . . . . . . . . . . . 66

Poster 33 "Pectinolytic Enzymes in a New True Cellulolytic Yeast-Like Fungus, Aureobasidium sp. CH-M-1018," R. Pérez, M. E. Flores, and C. Huitrón, National University of México, México . .67

Poster 34 "Microbial Conversion of High Rank Coals to Methane," E. R. Johnson, K. T. Klasson, R. Basu, J. C. Volkwein, E. C. Clausen, and J. L. Gaddy, University of Arkansas, Fayetteville, Arkansas . .68 
Poster 35 "Development of a Buffered Medium for Cellulase Fern wntation Studies with T. reesei Rut-C30," K. L. Kadam and W. J. Keutzer, Nacional Renewable Energy Laboratory, Golden, Colorado . . . .69

Poster 36 "Phanerochaete Mutants with Enhanced Ligninolytic Activity," S. N. Kakar, Argonne National Laboratory, Argonne, Illinois . . . . . . . . . . . . . . . . . . . . . . . .70

Poster 37 "Synergism in Cleaving Avicel by Clostridium thermocellum Cellulases Produced in Escherichia coli," S. V. Kalyuzhnyi, Autonomous University of Coahuila, México City, México; T. P. Mosolova and S. D. Varfolomeyev, M. V. Lomonosov Moscow University, Moscow, Russia; G. A. Velikodvorskaya, Institute of Molecuiar Genetics, Moscow, Russia . . . . . . . . 71

Puster 38 "The pH-Dependent Energetic Uncoupling of Zymomonas by Acetic Acid," H. G. Lawford and J. D. Rousseau, University of Toronto, Toronto, Ontario, Canada . . . . . . . . . . .72

Poster 39 "Effect of Oxygen on Ethanol Production by a Recombinant Zthanologenic E. coli B (pLOL297)," H. G. Lawford and J. D. Rousseau, University of Toronto, Toronto, Ontario, Canada . . . . . . .73

Poster 40 "Relative Rates of Ethanol Production by an Ethanologenic E.coli B (pLOL297) Using Mixtures of Glucose, Mannose, and Xylose," H. G. Lawford and J. D. Rousseau, University of Toronto, Toronto, Ontario, Canada . . . . . . . . . . . . . . . . . . . . . . . .74

Poster 41 "In Situ Photoprecipitation of Metallocatalysts for Molecular Hydrogen Production with Photosynthetic Water Splitting in Thylakoids," J. W. Lee, G. V. Tevault, S. Blankinship, R. Collins, andE. Greenbaum, Oak Ridge National Laboratory, Oak Ridge, Tennessee . . . . . .75

Poster 42 "Purification and Characterization of an Acetylesterase from Aspergillus niger," J. C. Linden, M. Samara, E. Thomas, M. Joy, and S. Decker, Colorado State University, Fort Collins, Colorado; M. Pecs, University of Technical Sciences, Budapest, Hungary; W. Adney and M. Himmel, National Renewable Energy Laboratory, Golden, Colorado . . . . . . . . . . . . . 76

Poster 43 "Synthesis of Cyclodextrin Glycosyl Transferase by Bacillus cereus for the Production of Cyclodextrins," R. Jamuna and S. V. Ramakrishna, Council of Scientific and Industrial Research, Trivandrum, Kerala, India . . . . . . . . . . . . . . . .77

Poster 44 "Mathematical Model of Substance Active Transport into Microbial Cells at Concentration Gradient," Y. R. Malashenko, I. G. Sokolov, and F. V. Muchnik, Ukrainian Academy of Sciences, Kiev, The Ukraine . . . . . . . . . . . . . . . . . . . . . . . .78

Poster 45 "Photobiological Conversion of Synthesis Gas into Biodegradable Plastics," P.-C. Maness and P. F. Weaver, National Renewable Energy Laboratory, Golden, Colorado . . . . . . . . . . . . . .79

Poster 46 "Evaluation of Discrete Cellulase Enzyme Activities from Anaerobic Digester Sludge Fed a Municipal Solid Waste Feedstock," C. J. Rivard, R. A. Nieves, N. J. Nagle, and M. E. Himmel, National Renewable Energy Laboratory, Golden, Colorado . . . . . . . . . . . . . . . . . .80

Poster 47 "Compositional Changes of Adsorbed Cellulases During Cellulose Hydrolysis," A. H. C. Yu and J. N. Saddler, University of British Columbia, Vancouver, British Columbia, Canada . . . .81

Poster 48 "Use of a Cellulose-Binding Domain to Measure the Accessibility of Various Cellulosic Substrates to Cellulases," D. Lee, K. Wong, A. Yu, J. N. Saddler, A. Warren, D. Killburn, and N. Gilkes, University of British Columbia, Vancouver, British Columbia, Canada . . . . . . . . .82

Poster 49 "Overproduction of the Cloned Xylanases from Alkalophilic Thermophilic Bacillus," A. Shendye, R. Gaikaiwari, and M. Rao, National Chemical Laboratory, Pune, India . . . . . . 83

Poster 50 "Autotrophic Growth of Desulfotomaculum orientis with Reduction of Sulfur Dioxide," C.-M. Lee and K. L. Sublette, Unjversity of Tulsa, Tulsa, Oklahoma . . . . . . . . . . . . .84

Poster 51 "Evaluation of $N_{2}$-Fixation by Stem and Root Nodules in Sesbania rostrata," S. Rajavelu, V. C. Saralabai, and M. Vivekanandan, Bharathidasan University, Tami'nadu, India . . . . . .85

Poster 52 "The Mechanism of Increasing Cellulase Biosynthesis Rate in Mycelial Fungus by L-Sorbose," D. Wang, Y.-b. Qu, and P.-j. Gao, Shandong University, Jinan, China . . . . . . . . . . . 86

Poster 53 "Photoenhanced Anaerobic Digestion of Organic Acids into Methane," P. F. Weaver and P.-C. Maness, National Renewable Energy Laboratory, Golden, Colorado . . . . . . . . . . . . .87 
Poster $54 \quad$ "Removal of Inhibition by Ammonium Ion in Nitrogenase-Dependent $\mathrm{H}_{2}$ Evolution of Marine Photosynthetic Bacterium Rhodopseudomonas sp. Strain W1S," K. Yagi, I. Maeda, K. Idehara, and Y. Miura, Osaka University, Osaka, Japan; T. Akano, K. Fukatu, and Y. Ikuta, Kansai Electric Power Company, Inc., Osaka, Japan; H. K. Nakamura, Mitsubishi Heavy Industries, Ltd.,

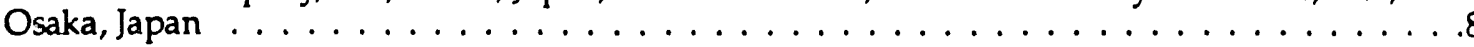

\section{Poster Session 3. Bioprocessing Research}

Poster 55 "Hydrodynamic Modeling of a Liquid Fluidized Bed Bioreactor for Coal Biosolubilization," M. Asif and J. N. Petersen, Washington State University, Pullman, Washington; T. C. Scott, Oak Ridge National Laboratory, Oak Ridge, Tennessee $\ldots \ldots \ldots \ldots$. . . . . . . . . . .89

Poster 56 "Conversion of Hydrogen Sulfide to Elemental Sulfur by Chlorobium thiosulfatophilum in a CSTR with a Sulfur Settling Separator," R. Basu, S. Ramakrishnan, E. C. Clausen, and J. L. Gaddy, University of Arkansas, Fayetteville, Arkansas . . . . . . . . . . . . . . .90

Poster 57 "High Yield Shake Flask Fermentation of Xylose to Ethanol," B. L. Boynton and J. D. McMillan, National Renewable Energy Laboratory, Golden, Colorado . . . . . . . . . . . . . . . . . 91

Poster 58 "Temperature Dependent Kinetics of Ethanol Fermentation Using a Self-Aggregating Saccharomyces uvarum," C. S. Chen, S. I. Wang, and L. G. Chen, Da-Yeh Institute of Technology, Chang-Hwa, Taiwan; L. F. Chen, Purdue University, West Lafayette, Indiana

Poster 59 "Cellulose Hydrolysis Using Zinc Chloride as a Solvent and Catalyst," N. J. Cao, C. S. Gong, and L. F. Chen, Purdue University, West Lafayette, Indiana . . . . . . . . . . . . . . .93

Poster 60 "Cellulase and Xylanase Production by Aspergillus sp. G-393," S. I. Wang, L. G. Chen, and C. S. Chen, Da-Yeh Institute of Technology, Chang-Hwa, Taiwan; L. F. Chen, Purdue University, West Lafayette, Indiana . . . . . . . . . . . . . . . . . . . . . .94

Poster 61 "Ethanol Fermentation in a Tower Fermentor Using Self-Aggregating Sactharomyces uvarum," C. S. Chen, Da-Yeh Institute of Technology, Chang-Hwa, Taiwan; C. S. Gong and L. F. Chen, Purdue University; West Lafayctte, Indiana _ . . . . . . . . . . . . . . . . . . . 95

Poster 62 "Fight Against Bacterial Contamination in Industrial Alcoholic Fermentations," M. de Miniac, l'Union Nationale des Distillateurs d'Alcool, Paris, France . . . . . . . . . . . . . . . .96

Poster 63 "Cheese Whey Fermentation for Single Cell Protein Production and Pollution Potential Reduction," A. E. Ghaly, Technical University of Nova Scotia, Halifax, Nova Scotia, Canada . .97

Poster 64 "Effect of Various Factors on the Efficiency of Enzymatic Cellulose Hydrolysis in the Intensive Mass Transfer Reactor," A. V. Gusakov and A. P. Sinitsyn, M.V. Lomonosov Moscow State Univers'iy, Moscow, Russia; I. Yu. Davydkin and V. Yu. Davydkin, Research and Industrial Assuciation DION Ltd., Moscow, Russia

Poster 65 "Aqueous Biphasic Systems for Biological Particle Partitioning," D. T. L. Hawker, R. H. Davis and P. Todd, University of Colorado, Boulder, Colorado, and G. Johansson, University of Lund, Lund, Sweden

Poster 66 "Development of a Biparticle Fluidized Bed Bioreactor for the Continuous and Simultaneous Fermentation and Purification of Lactic Acid," E. N. Kaufman, S. P. Cooper, and B. H. Davison, Oak Ridge National Laboratory, Oak Ridge, Tennessee

Poster 67 "Study of Coal Particle Segregation in a Liquid Fluidized Bed: In Situ Visualization Using Fluorescence Microscopy," E. N. Kaufman and T. C. Scott, Oak Ridge National Laboratory, Oak Ridge, Tennessee

Poster 68 "Immobilization of Invertase onto a Copolymer of Methacrylamide and N,N'-Methylencbis(acrylamide) and Characterization," C.-T. Huang and W.-C. Lee, Chung Yuan Christian University, Chung Li, Taiwan . . . . . . . . . . . . . . . . . . . . . . . . . . 102

Poster 69 "Fed Batch Fermentation of Sweet Sorghum Carbohydrates to Ethanol by a Mixed Culture," V. Lezinou, P. Christakopoulos, D. Kekos, and B. J. Macris, National Technical University of Athens, Athens, Greece . . . . . . . . . . . . . . . . . . . . . 103 
Poster 70 "On the Mechanism of Direct Bioconversion of Sweet Sorghum Carbohydrates to Ethanol: Effect of Cellulolytic Enzymes," V. Lezinou, P. Christakopoulos, D. Kekos, and B. J. Macris, National Technical University of Athens, Athens, Greece . . . . . . . . . . . . . . . . . 104

Poster 71 "Bioconversion of MSW to Lactic Acid by Lactobacillus Species," T. A. McCaskey and S. Zhou, Auburn University, Auburn, Alabama; R. C. Strickland, Tennessee Valley Authority, Muscle Shoals, Alabama . . . . . . . . . . . . . . . . . . . . . . . . . . . . . 105

Poster 72 "Arabinose Utilization by Xylose-Fermenting Yeast and Fungi," J. D. McMillan and B. L. Boynton, National Renewable Energy Laboratory, Golden, Colorado . . . . . . . . . . 106

Poster 73 "Production of Lactic Acid from Lignocellulosic Biomass," N. Padukone, S. Schmidt, and B. Goodman, National Renewable Energy Laboratory, Golden, Colorado . . . . . . . . . . . 107

Poster 74 "On-Line Monitoring of Fresh-Weights in Carrot Hairy-Root Cultures by Conductometry," H.-H. Ko, D.-H. Park and B. Hwang, Chonnam National University, Kwangju, Korea; R. D. Tanner, Vanderbilt University, Nashville, Tennessee . . . . . . . . . . . . . . . . . . . 108

Poster 75 "Acetone-Butanol Production from Biomass by Simultaneous Saccharification and Extractive Fermentation," M. M. Shah, University of Illinois, Urbana, Ilinois; Y. Y. Lee, Auburn University, Auburn, Alabama . . . . . . . . . . . . . . . . . . . . . . . . . . . . . 109

Pester 76 "Solid State Fermentation of Petrocrop Spent Residues for Production of the Cellulase Enzyme by Wheat Litter Decomposing Fungi," D. K. Sharma and M. Tiwari, Indian Institute of Technology - Delhi, New Delhi, India; B. K. Behera, M. D. University, Rohtak, India . . . . . . 110

Poster 77 "Alpha and Glucoamylase Production in Endomycopsis capsularis Mutants by Sol" _ State Fermentation," S. Singh, K. S. Bath, M. Singh, and S. Soni, Guru Nanak Dev University,

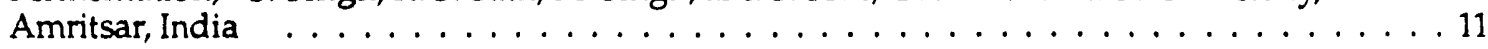

Poster 78 "Ethanol Production from Lignocellulosic Biomass: Evaluation of SSF Conditions and Parameters," T. K. Smith and G. P. Philippidis, National Renewable Energy Laboratory, Golden, Colorado . . . . . . . . . . . . . . . . . . . . . . . . . . . . . .112

Pos er 79 "Fermentations by Included Yeasts in Doiabled Layored Alginate Beads," P. Taillandior and M. L. Delia-Dupuy, Laboratoire de Génie Ehimique, Toulouse-Cedex, France; C. Sanchez, Lallemand Inc., Colomiers, France; P. Strshaiano, ENSIGC, Toulouse-Cedex, France . . . . . . . 113

Poster 80 "A Two Zone Mixing Model for Decribing the Kinetics of a Batch Pectin-Pectinase Reaction Process," W. Tseng, A. Prokop, and R. D. Tanner, Vanderbilt University, Nashville, Tennessee . 114

Poster 81 "Bioconversion of Vanillin to Vanillic Acid in One- and Two-Phase Systems," G. Baré, V. Delaunois, R. Rikir, and P. Thonart, Université de Liège, Liège, Belgium . . . . . . . . . . 115

Poster 82 "Simulation Model (Methane) as a Tool for Effective Biogas Production During Anaerobic Conversion of Complex Organic Material," V. A. Vavilin, V. B. Vasiliev, S. V. Rytow, and A. V. Ponomarev, Russian Academy of Sciences, Novo-Basmannaja, Russia . . . . . . . . . . 116

Poster 83 "SSF Comparison of Selected Woods from Southern Saw Mills," T. B. Vinzant, L. R. Ponfick, N. J. Nagle, T. I. Ehrman, K. M. Magill, and M. E. Himmel, National Renewable Energy Laboratory, Golden, Colorado; J. B. Reynolds, South Point Ethanol, South Point, Ohio

Poster 84 "Performance of a Fluidized Bed Reactor with Immobilized Enzyme," G. M. Zanin, L. M. Kambara, L. P. V. Calsavara, and F. F. de Moraes, Maringá State University, Maringá, Parana, Brazil . . . . . . . . . . . . . . . . . . . . 118

\section{Poster Session 4. Process Economics and Commercialization}

Poster 85 "Silage Processing of Forage Biomass to Alcohol Fuels," J. C. Linden, L. L. Henk, V. G. Murphy, K. D. Lange, and R. P. Tengerdy, Colorado State University, Fort Collins, Colorado . . . . . . 119

Poster 86 "Analysis of Renewable Feedstocks for the Production of Commodity Chemicals," J. K. Polman, Idaho National Engineering Laboratory, Idaho Falls, Idaho . . . . . . . . . . 120 


\section{Poster Session 5. Environmental Biotechnology}

Poster 87 "Removal of Carbonyl Sulfide and Hydrogen Sulfide from Synthesis Gas by Chlorobium thiosulfatophilum," R. Basu, K. T. Klasson, E. C. Clausen, and J. L. Gaddy, University of Arkansas, Fayetteville, Arkansas . . . . . . . . . . . . . . . . . . . . 121

Poster 88 "The Removal of Volatile Organics in a Gas-Phase Bioreactor," B. H. Davison and J. E. Thompson, Oak Ridge National Laboratory, Oak Ridge, Tennessee . . . . . . . . . . . . . 122

Poster 89 "Cellulase Activity of Trichoderma reesei (Rut-C30) on Municipal Solid Waste,"A. Maxey, H. Huckabay, X.-J. Chen, and B. B. Elmore, Louisiana Technical University, Ruston, Louisiana 123

Poster 90 "Carbon Dioxide Fixation by Microalgal Photosynthesis Using Actual Flue Gas Discharged from a Boiler," Y. Ikuta and Y. Hukuda, Mitsubishi Heavy Industries, Ltd., Tokyo, Japan; A. Hamasaki and N. Shioji, Hyogo, Japan; T. Makita, K. Hirayama, H. Matsuzaki, and T. Tukamoto, Tohoku Electric Power Company, Inc., Miyagi, Japan . . . . . . . . . . . . . . . 124

Poster 91 "Biotechnology of Associative Nitrogen Fixation," T. G. Korzhenevskaya and M. V. Gusev, Moscow State University, Moscow, Russia . . . . . . . . . . . . . . . . . . . . . . . . 125

Poster 92 "Binding of Dissolved Uranium by Pseudomonas aeruginosa CSU," N. D. H. iMunroe, Florida International University, Miami, Florida; J. D. Bonner, J. M. Norman, and B. D. Faison, Oak Ridge National Laboratory, Oak Ridge, Tennessee; R. Williams, University of Tennessee, Knoxville, Tennessee; K. F. Pattison, University of Pittsburgh, Bradford, Pennsylvania . . . 126

Poster 93 "The Effect of Media Composition on EDTA Degradation by Agrobucterium radiobacter," A. V. Palumbo, S. Y. Lee, and P. Boerman, Oak Ridge National Laboratory, Oak Ridge, Tennessee

Poster 94 "Potential for Microbial Growth in Arid Subsurface Sediments," A. V. Palumbo, A. Parker, J. McCarthy, T. J. Phelps, and J. Strong-Gunderson, Oak Ridge National Laboratory, Oak Ridge, Tennessee

Poster 95 "Bioremediation of Petroleum Hydrocarbons in Soil Column Lysimeters from Kwajalein Island," T. J. Phelps, R. L. Siegrist, N. E. Korte, D. A. Pickering, J. M. Strong-Gunderson, A. V. Palumbo, J. F. Walker, and C. M. Morrissey, Oak Ridge Nation:al Laboratory, Oak Ridge, Tenessee; R. Mackowski, University of Tennessee, Knoxville, Tennessee . . . . . . . . . . . . . 129

Poster 96 "Microbial Biosorption of Nickel in Complex Aqueous Wastes," M. Reeves and L. Corder, Oak Ridge National Laboratory, Oak Ridge, Tennessee . . . . . . . . . . . . . . . . . . . . 130

Poster 97 "Biofuels Full Fuel Cycle Analysis," S. R. Bull, C. J. Riley, and K. S. Tyson, National Renewable Energy Laboratory, Golden, Colorado; R. Costello, U.S. Department of Energy,

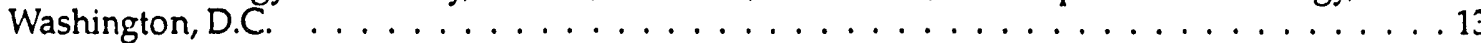

Poster 98 "Kinetic Regularities of Non-Stationary Behavior of UASB-Reactor Under Various Regimes of Feeding," V. I. Sklyar, M. A. Davlyatshina, and S. D. Varfolomeyev, M. V. Lomonosov Moscow University, Moscow, Russia; S. V. Kalyuzhnyi, Autonomous University of Coahuila, Saltillo, México . . . . . . . . . . . . . . . . . . . . . . . . . . . 132

Poster 99 "Differential Bioavailability of Deep Subsurface Natural Organic Matter to Microbial Isolates: Implications to In Situ Bioremediation," J. M. Strong-Gunderson, A.V. Palumbo, J. McCarthy, S. Scarborough, and T. Mehlhorn, Oak Ridge National Laboratory, Oak Ridge, Tennessee . . . . 133

Poster 100 "Porphyrin-Catalyzed Reduction of Nitroaromatics for the Treatment of Munitions Wastes," J.-G. Cho and K. L. Sublette, University of Tulsa, Tulsa, Oklahoma . . . . . . . . . . . . . . . 134

Poster 101 "Large-Scale Production of Thiobacillus denitrificans Biomass to Support Pilot and Field Tests of Microbial Sulfide Oxidation," S. Hason, B. Rajganesh, and K. L. Sublette, University of Tulsa,

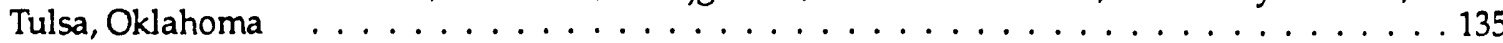

Poster 102 "A New Biomaterial to Eliminate Heavy Metal Ions from their Dilute Waste Solutions," K. Sıyama, Y. Fukazawa, and Y. Umetsu, Tohoku University, Sendai, Japan . . . . . . . . 136

Poster 103 "A New Way of Investigation for the Control of Slurry Odors," P. Antoine, J. Godefroid, P. Anselme, and P. Thonart, Centre Wallon de Biologie Industrielle, Gembloux, Belgium; 
M.-P. De Poorter, M. Vande Woestyne, P. Van Rolleghem, and W. Verstraete, Laboratorium voor Mikrobiele Ekologie, Gent, Belgium . . . . . . . . . . . . . . . . . . . . . 137

Po-ter 104 "Modeling and Optimization of Fed-Batch Bioreactors for Treatment of Toxic Chemicals Using Neural Networks," Q. Chen and W. A. Weigand, University of Maryland, College Park,

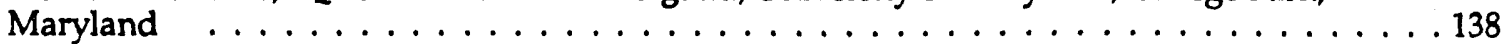

Poster 105 "Reduction of Carbon Dioxide Accumulation by Use of Alternative Fuels from Biomass,"

C. E. Wyman, National Renewable Energy Laboratory, Golden, Colorado 139 


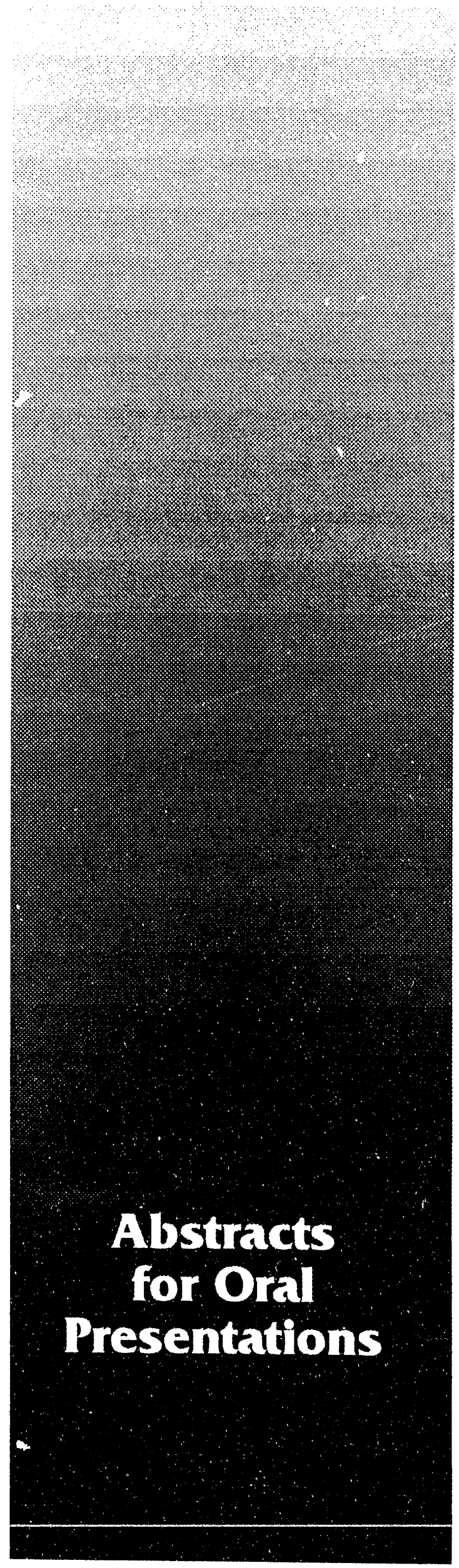


Paper 1

\title{
TWO-TEMPERATURE DILUTE-ACID PREHYDROLYSIS OF HARDWOOD XYLAN USING A PERCOLATION PROCESS
}

\author{
R. Torget and T. Hsu \\ National Renewable Energy Laboratory \\ Golden, CO 80401
}

Many chemomechanical pretreatments of hardwoods have been proposed to address the recalcitrance of the cellulose fraction to saccharification by cellulases for subsequent ethanol production. One such process involves comminution of the biomass followed by dilute sulfuric acid prehydrolysis to remove the hemicelluloses. The cellulose can then be saccharified and fermented into ethanol.

Process analyses of proposed hardwood-to-ethanol plants have indicated that the yield of all potentially fermentable sugars is a key parameter. Thus, hydrolyzing the hemicellulosic stigars to their respective monomers and concomitantly preventing their degradation is of paramount importance. Hardwood hemicelluloses have been found to be very similar chemically. It has been reported in the literature that the acid catalyzed hydrolysis of the predominant hemicellulosic component, xylan, can be modeled by two pseudofirst order reactions. The first reaction describes an "easily hydrolyzable xylan," which accounts for 60\%-70\% of the xylan, and the second reaction accounts for the hydrolysis of the remaining xylan. Current pretreatment process designs use a single temperature for hemicellulose hydrolysis that do not exploit the biphasic kinetics.

In this study, we propose a novel two-temperature dilute sulfuric acid prehydrolysis that applies a lower temperature to hydrolyze the easily hydrolyzable xylan, and a higher temperature to hydrolyze the remaining xylan. Preliminary data, including a parametric analysis of the proposed pretreatment process, will be presented to describe near quantitative yields of hemicellulosic sugars using a percolation process. Other data will include glucan solubilized and subsequently degraded, enzymatic digestibility of the substrates produced, as well as a preliminary cost analysis comparing percolation prehydrolysis with a continuous screw tubular reactor prehydrolysis. 
Paper 2

\title{
EFFECTS OF THE DILUTE ACID AND STEAM EXPLOSION PRETREATMENTS ON THE CELLULOSE STRUCTURE AND THE KINETICS OF THE CELLULOSIC FRACTION HYDROLYSIS BY DILUTE ACIDS OF DIFFERENT LIGNOCELLULOSIC MATERIALS
}

\author{
J. E. Carrasco, J. M. Martinez, M. C. Saiz de Bustemente, and F. Saez \\ Centro de Desarrollo de Energias Renovables \\ Madrid, Spain
}

The suitability of any treatment of lignocellulosic biomass as a previous step to produce the hydrolysis of the cellulosic fraction is currently linked to its effectiveness to produce the separation of the cellulose as well as to its capacity to enhance the susceptibility of the polisugar to the ulterior hydrolytic attack. In addition, it is very important to take into account the extent of cellulose hydrolysis and glucose degradation produced by the pretreatment conditions, since this can be the determinant for the economy of the hydrolytic process.

Two of the more employed pretreatments for lignocellulosic biomass are the dilute acid at moderate temperatures $\left(100^{\circ}-200^{\circ} \mathrm{C}\right)$ and the steam explosion. Both cause the hydrolysis of the hemicellulose fraction but also produce an important extent of cellulose degradation if the temperature and/or acid concentration condition are not well selected. It has also been extensively reported by many authors that the effects of these pretreatments, and in particular of steam explosion, on the susceptibility of the cellulose to the enzymatic hydrolysis, but much lower attention has been paid to those for the ulterior cellulose hydrolysis with dilute acids.

According to most of the authors, the crystallinity index of the cellulosic fraction is one of the most important factors affecting the kinetics of cellulose hydrolysis with dilute acids, and thus it is of interest to study the effects of the pretreatments on this parameter in order to determine its effectiveness to modify the susceptibility of cellulose to the ulterior dilute acid hydrolysis.

In this context, the ai: $n$ of the work proposed is to determine, under comparative experimental conditions, the effects that both dilute acid and steam explosion pretreatments have on the crystallinity index of the cellulose of different types of lignocellulosic materials, and correlate them to the observed changes of the dilute acid hydrolysis kinetic parameters of the pretreated substrates when compared to the nonpretreated ones.

For the purpose of this work, the next raw materials have been employed:

- hardwoods: poplar, oak, eucalyptus

- softwoods: pinewood (P. sylvestris; $P$. pinaster)

- agriculture residues: wheat straw, vineyard prunes

- herbaceous energetic crops: sweet sorghum bagasse, thistle Cynara cardunculus biomass

The biomasses have been submitted to different pretreatment conditions in order to achieve in each case at least $60 \%$ of hemicellulose hydrolysis with a low or moderate cellulose hydrolysis ( $2 \%-25 \%)$.

The crystallinity index of the cellulosic fraction as well as the kinetic parameters of the cellulose acid hydrolysis reaction before and after the pretreatments have been determined for each substrate. The results have been compared to those obtained under similar treatment conditions with sigma-cell, a very purified and crystalline cellulosic substrate.

According to the results obtained, it can be concluded that the dilute acid and steam explosion pretreatments do not have a significant action on the crystalline cellulose and the increases of the crystallinity indexes 
observed in all cases studied seem to be due to the hydrolysis of the amorphous cellulose during the pretreatment.

On the contrary to the steam explosion, the dilute acid pretreatments increase the value of the rate factor of the remaining cellulose hydrolysis reaction with dilute acids.

This situation is quite different to that reported by many authors for cellulose enzymatic hydrolysis. 


\title{
EFFECT OF PRETREATMENT AND POST-TREATMENT ON FERMENTATION OF MOLASSES
}

\author{
S. Inamdar \\ PRAJ Conseltech PVT. LTD. \\ Pune 411 004, India
}

Process for fermentation of sugarcane molasses to ethanol is considered. Fermentable sugars in the molasses are converted to ethanol by yeast Saccharomyces cerevisae.

Method of pretreatment of molasses is as follows:

1. Dilution of molasses.

2. Heating of molasses.

3. Settling of diluted, hot molasses and removal of sludge.

4. Cooling of diluted molasses.

5. Washing of sludge for recovery of sugars and recycle of wash-water.

This pretreatment is carried out with following objectives:

1. To minimize nonfermentable suspended solids in the fermenting broth.

2. To minimize scaling, fouling and choking during downstream processing like yeast separation and distillation.

3. To achieve certain degree of pasteurization of molasses.

Method of post-treatment of fermented molasses is as follows:

1. Settling of fermented molasses (broth) and removal of sludge.

2. Washing of sludge for recovery of alcohol and recycle of wash-water.

This post-treatment is carried out with the following objective:

To minimize scaling, fouling, and choking during downstream processing like distillation and evaporation.

Both the methods have been operated on plant-scale for a rcasonably long period and have certain advantages and disadvantages. Comparison of various parameters and results is made based on plant data to evaluate suitability and is presented.

Overall it emerges out that post treatment method is superior in terms of its effectiveness and economics.

Process and equipment for both the methods and operating data from respective plants will be presented. 


\title{
Paper 4
}

\section{DETERMINATION OF REACTION KINETIC:S OF BARLEY STRAW USING THERMOGRAVIMETRIC: ANALYSIS}

\author{
A. E. Ghaly and A. Ergudenler \\ Technical University of Nova Scotia \\ Halifax, Nova Scotia, Canada B3J 2 X4
}

Thermogravimetric analysis (TGA) and differential thermal analysis (DTA) were conducted on different varieties of barley straws in an oxidizing atmosphere of $15 \%$ Oxygen and $85 \%$ Nitrogen. The thermal degradation of straw was studied from ambient temperature to $700^{\circ} \mathrm{C}$ using a heating rate of $20^{\circ} \mathrm{C} / \mathrm{min}$. Applying thermo-analytical techniques to reaction kinetics, the order of reaction, pre-exponential factor and energy of activation were determined from thermogravimetric curves. Two distinct reaction zones were observed on the TGA and DTA curves. Because of the two step nature of the thermal degradation of straw, it was essential to determine the kinetic parameters for each zone separately. Lower activation energy and pre-exponential factors were observed for straws as compared to cellulose due to the high inorganic material and silica contents of the first. 


\title{
ETHANOL FERMENTATION OF AFEX-TREATED SWITCHGRASS BY GENETICALLY-ENGINEERED KLEBSIELLA OXYTOCA
}

\author{
S. Reshamwala, B.T. Shawky, V.M. Latimer, and B.E. Dale \\ Texas A\&M University \\ College Station, TX 77843-2476
}

\begin{abstract}
The structural carbohydrates cellulose and hemicellulose must be economically hydrolyzed and fermented if fuel ethanol from lignocellulosics is to achieve its potential. The ammonia fiber explosion (AFEX) process is economical (less than $\$ 10$ per ton biomass treated) and enables essentially complete enzymatic hydrolysis in 24 hours or less of treated herbaceous crops and crop residues at enzyme levels of about 5-10 IU/gram dry biomass. Past fermentation results on AFEX-derived sugars are briefly reviewed. Total sugar yields and compositions for AFEX-treated corn fiber, sugar cane bagasse and switchgrass at enzyme loadings of $5 \mathrm{IU} /$ gram and less are summarized. A genetically engineered Klebsiella oxytoca developed by Dr. Lonnie Ingram was used to ferment enzymatically hydrolyzed sugars from AFEX-treated switchgrass. The resulting ethanol yields are greater than 70 gallons/ton. Carbohydrate consumption profiles and other fermentation parameters are also reported.
\end{abstract}




\title{
Paper 6
}

\section{INFLUENCE OF STORAGE CONDITIONS ON THE PRODUCTION OF LIQUID FUELS FROM HERB ACEOUS BIOMASS}

\author{
F. A. Agblevor, D. Wang, B. Rejai, A. Wiselogel, and H. L. Chum, \\ National Renewable Energy Laboratory \\ Golden, CO 80401
}

Herbaceous biomass materials, switchgrass (Panicum virgatum L.), tall fescue (Festuca arundinacea Schreb.), alfalfa/orchardgrass (Medicago sativa L./Dactylis glomerata L.), sericea lespedeza (Lespedeza cuneata), and sugarcane bagasse (Saccharum spp. hybrid) that were stored from 3 to 44 weeks were used in these studies. The biomass materials were pyrolyzed at $600^{\circ} \mathrm{C}$ and atmospheric pressure, and the volatile pyrolysis products were analyzed in real time on a molecular beam mass spectrometer (MBMS). The pyrolysis products were also catalytically upgraded using a commercial zeolite catalyst. The nitrogen, lignin, and ash contents from the weathered fraction of the biomass increased relative to the fresh biomass. Significant losses of carbohydrates and extractives occurred in the weathered fraction of the biomass, whereas in the unweathered fraction, the composition was similar to that of fresh biomass. The results also showed that the yield of hydrocarbons from the weathered fraction of the biomass was significantly lower than the yield from fresh biomass. However, the weathered fraction of the herbaceous biomass is relatively small compared to the total biomass stored. The nitrogen content of the biomass also had a significant negative effect on the yield of hydrocarbons. 


\title{
SELECTIVE DEHYDRATION OF GLUCOSE TO ORGANIC ACIDS IN MICROPOROUS PILLARED-CLAY CATALYSTS
}

\author{
K. Lourvanij and G.L. Rorrer \\ Oregon State University \\ Corvallis, OR 97331
}

Reactions of glucose with microporous, pillared-clay catalysts were studied to see if this heterogeneous system could produce oxygenated hydrocarbons by shape-selective, acid-catalyzed processes at fairly low temperatures. Acidic, pillared-clay catalysts with nominal gallery (pore slit) heights ranging from 10 to 25 angstroms were synthesized by pillaring montmorillonite with $\mathrm{Al}, \mathrm{Cr}$ and Fe oxides. Gallery heights of at least 10 angstroms allowed the 9 angstrom glucose molecule to diffuse directly into the microporous matrix of the catalyst. In 'batch kinetic experiments, these catalysts were reacted with aqueous glucose in a well-mixed Parr reactor at $130^{\circ}$ to $180^{\circ} \mathrm{C}$ for reaction times of 0 to $24 \mathrm{~h}$. Unreacted glucose and oxygenated hydrocarbon products were measured by HPLC. Glucose conversions of $100 \%$ were obtained within $6 \mathrm{~h}$ at $150^{\circ} \mathrm{C}$, and the glucose conversion rate increased with increasing gallery height. Several acid-catalyzed reactions were identified, including isomerization of glucose to fructose, partial dehydration of glucose to 5-hydroxymethylfurfural (HMF), rehydration and cleavage of HMF to formic acid and 4-oxopentanoic acid, and carbonization. Selectivity toward final organic acid products increased as the gallery height increased, with Fe-pillared catalysts showing the highest selectivity of 0.5 mole organic acids formed per mole of glucose reacted. 


\title{
THE USE OF ENZYME KECYCLE DURING HYDROLYSIS OF PRETREATED CELLULOSE
}

\author{
L.P. Ramos and J.N. Saddler \\ University of British Columbia \\ Vancouver, B.C., Canada V6T 124
}

Steam pretreatment of $\mathrm{SO}_{2}$-impregnated Eucalyptus viminalis chips, followed by alkaline peroxide treatment to extract most of the lignin component, was demonstrated to be an effective way of enhancing the enzymatic hydrolysis of cellulose, as well as improving the efficiency of both enzyme recovery and recycle. When an enzyme preparation (Celluclast plus Novozym) containing a final activity of $10 \mathrm{FPU} / \mathrm{g}$ cellulose was used to hydrolyse a $5 \%(\mathrm{w} / \mathrm{v}$ ) suspension of pernxide-treated eucalyptus, more than $60 \%$ of the substrate could be hydrolysed to glucose within $24 \mathrm{~h}$. As most of the added cellulase astivily was shown to associate with the unhydrolysed residue, the possibility of reusing the adsorbed enzymes to hydrolyse several batches of fresh substrate was investigated. Enzyme recycle was carried out by recovering and recycling the $24 \mathrm{~h}$ hydrolysis residue containing the adsorbed enzymes. At each recycle step, enough -glucosidase activity (Novozym) and fresh substrate was supplemented to the resiciue to reconstitute the initial $5 \%$ hydrolysis conditions. The glucose yields obtained after each of the seven consecutive hydrolysis steps were relatively constant. However, there was a gradual decrease in the amount of protein recovered in solution after each hydrolysis step. We also conducted an experiment where the ultrafiltration retentate of the previous hydrolysis step was fed back into the reaction, rather than supplementing the system with fresh-glucosidase activity at each recycling step. These results suggested that thr semicontinuous hydrolysis of this substrate could be achieved without the addition of fresh enzyme for at leasi seven consecutive hydrolysis experiments. 


\title{
ENDOGLUCANASE E1 FROM ACIDOTHERMUS CELLULOLYTICUS IS A FAMILY A CELLULASE
}

\author{
S.R. Thomas, R.A. Laymon, M.P. Tucker, T.B. Vinzant,
} W.S. Adney, R.A. Nieves, J.O Baker, and M.E. Himmel

\section{National Renewable Energy Laboratory Golden, CO 80401}

United States patent No. 5,110,735 awarded to NREL/MRI describes a high molecular weight endoglucanase from culture broths of $A$. cellulolyticus. Another endoglucanase, E1, was highly purified from $A$. cellulolyticus and described in a Continuation in Part patent (pending). E1 is an especially important enzyme because it not only displays a high specific activities on carboxymethylcellulose (CMC), but also because it is thermostable. Overexpression of recombinant cellulase genes from selected industrial hosts poses high potential for the production of low-cost cellulases. A lambda library was constructed from partially digested $A$. cellulolyticus DNA and screened on indicator plates for CMCase activity. Several positive isolates were restriction mapped. Fragments were subcloned and rescreened for CMCase activity. The DNA sequence of one highly active gene has been determined. The polypeptide defined by the sequence contains a typical cellulose-binding domain at the C-terminus connected by a proline/threonine-rich linker region to a catalytic domain which is homologous to Family A cellulases. Family A cellulases also include certain enzymes from Trichoderma reesei, Clostridium thermocellum, Ruminococcus albus, Caldocellum saccharolyticum, and Erwinia chrysanthemi. 


\title{
ENHANCEMENT OF THE HYDROLYTIC ACTIVITY OF CELLOBIOHYDROLASE I BY THE COVALENT ATTACHMENT OF PENTAAMINE RUTHENIUM
}

\author{
B.R. Evans ${ }^{a}$, R.M. Margalit ${ }^{b}$, and J. Woodward ${ }^{a}$ \\ ${ }^{a}$ Oak Ridge National Laboratory \\ Oak Ridge, TN 37831-6194 \\ bet Propulsion Laboratory \\ Pasadena, CA 91109
}

Purified cellobiohydrolase I (CBH I) from Trichoderma reesei was modified by covalent attachment of pentaamine ruthenium (III). The modified enzyme was found to possess enhanced specific activity toward the model substrate, p-nitrophenyl cellobioside, and crystalline cellulose (Avicel). Analysis of the modified enzyme by atomic absorption spectroscopy indicated one pentaamine ruthenium moiety to be attached per mol CBH I. The site of attachment appears to reside in the catalytic core of CBH I based on electrophoretic analysis of proteolytic digests of the modified enzyme. Using p-nitrophenyl cellobioside as the substrate, a 1.4-fold increase in the inhibition constant for cellobiose over that of the native enzyme was observed for the modified enzyme. Relief of inhibition by cellobiose may be a reason for the enhancement of activity observed with the pentaamine ruthenium (III)-modified CBH I. The modified enzyme also appeared to hydrolyze newspaper (a lignocellulosic substrate) to a greater extent than the native enzyme. 


\title{
ORGANISM DEVELOPMENT AND CHARACTERIZATION FOR ETHANOL PRODUCTION USING THERMOPHILIC BACTERIA
}

\author{
T.R. Klapatch, D.A. Hogsett, S. Baskaran, \\ S. Pal, and L.R. Lynd \\ Dartmouth College \\ Hanover, NH 03755
}

\begin{abstract}
Although the potential and advantageous features of thermophilic bacteria for ethanol production have been recognized, several disadvantageous features and/or gaps in current understanding prevent application. These include less than theoretical ethanol yields resulting from branched catabolic pathways, an ethanol tolerance for growth that is likely lower than more conventional ethanol producing organisms, and growth medium formulation. Research addressing these topics will be presented and considered in a process context. Current obstacles to application of molecular techniques to thermophiles will be discussed. Results will be presented from experiments ultimately aimed at pathway engineering to enhance ethanol yields, including characterization of restriction sequences operative in Clostridium thermocellum, cloning key catabolic enzymes, and achieving transformation and foreign gene expression. Ethanol tolerance is investigated for both $C$. thermocellum and Clostridium thermosaccarolyticum. Several methods are employed, including an innovative approach involving measurement of effluent substrate concentrations in continuous culture. The impact of adaptation, temperature, and the relationship between ethanol inhibition of cellulase activity and growth will be examined and evaluated. Inadequate growth media has impeded progress and evaluation of thermophiles for ethanol production. Data are presented that explore the ability of various medium recipes to support growth at high substrate concentrations.
\end{abstract}




\title{
STIMULATORY EFFECT OF RED LIGHT ON STARCH ACCUMULATION IN MARINE GREEN ALGA, CHLAMYDOMONAS SP. MGA 161
}

\author{
K. Yagi ${ }^{\mathrm{a}}$, K. Hamada ${ }^{\mathrm{a}}$, K. Hirata ${ }^{\mathrm{a}}$, K. Miyamoto ${ }^{\mathrm{a}}$, Y. Miura ${ }^{\mathrm{a}}$, \\ T. Akano ${ }^{b}$, K. Fukatu ${ }^{b}$, Y. Ikuta ${ }^{c}$, and H. K. Nakamura ${ }^{c}$ \\ asaka University \\ Osaka, Japan \\ ${ }^{b}$ Kansai Electric Power Company, Inc. \\ Osaka, Japan \\ ${ }^{c}$ Mitsubishi Heavy Industries, Ltd. \\ Osaka, Japan
}

Production of a clean renewable energy source, hydrogen, by biophotolysis of water is an ideal solar energy conversion system. We proposed the stable biophotolysis system with an alternating light/dark cycle using green alga and photosynthetic bacterium. The green alga accumulates starch by photosynthesis in the daytime and the starch degrades to produce hydrogen under anaerobic conditions in the night. The photosynthetic bacterium produce hydrogen in the light from organic compounds, such as acetate and ethanol, secreted from alga during dark fermentation. In this study we tried to enhance the photosynthetic starch accumulation in green alga and found that red light illumination remarkably increase the starch accumulation.

Marine green alga, Chlamydomonas sp. MGA 161, was cultivated under red or white light at an intensity of $25 \mathrm{~W} / \mathrm{m}^{2}$ in modified Okamoto medium at $30^{\circ} \mathrm{C}$. The amount of starch accumulated under red light was 2 times more than that accumulated under white light. The stimulatory effect was expressed within 6 hours of illumination. The red light-illuminated alga produced 1.7 times more hydrogen and ethanol under dark fermentation. Further increase of starch accumulation was observed in the alga cultivated at $15^{\circ} \mathrm{C}$ in the presence of $15 \% \mathrm{CO}_{2}$ under red light. 


\title{
BIOCHEMISTRY OF MICROBIALLY MEDIATED ORGANIC SULFUR REMOVAL
}

\author{
J.R. Gallagher, E.S. Olson, and D.C. Stanley \\ Energy and Environmental Research Center, \\ University of North Dakota \\ Grand Forks, ND 58202
}

Microbial desulfurization of fossil fuels appears to be an attractive technology since it has the potential to be low in capital costs, to be exquisitely specific in removal, and to be more environmentally acceptable than current technology. Two types of microbial desulfurization biochemistries have been described: a carbondestructive pathway, also known as the Kodama path; and a sulfur-specific pathway. Recently, pathway intermediates for the sulfur-specific desulfurization of the model compound dibenzothiophene have been identified. The identification of these intermediates has allowed for a revision of the sulfur-specific or $4 S$ pathway. Studies are underway to probe regulation and mechanisms involved in sulfur-specific desulfurization. In addition, products and intermediates in the carbon-destructive pathway have been identified. Since the genes for the carbon-destructive pathway have been cloned and sequenced, we can relate the chemistry to the gene identities. Application of the biochemistry of these two pathways to fossil fuel desulfurization is discussed. 


\title{
CELL SEPARATIONS USING TARGETED MONOCLONAL ANTIBODIES AGAINST OVERPRODUCED SURFACE PROTEINS
}

\author{
K. Tadikonda and R. H. Davis \\ Department of Chemical Engineering \\ University of Colorado \\ Boulder, CO 80309-0424
}

One of the challenges for today's biotechnologists is to obtain a functionally homogeneous population of cells from a mixture containing different types of cells. For example, the problem arises when plasmid-bearing, productive bacteria are to be maintained as the dominant strain in a bio-reactor. We have $E$. coli strain that produces a plasmid-mediated foreign protein of interest. However, when cells lose the plasmid, they start over-producing proteinaceous, type 1 pili on their surfaces. We wish to purge these piliating cells as they as produced, from a continuous fermentation of productive cells by using monoclonal antibodies that bind to the pili. We are performing fundamental studies to determine a strategy to achieve this goal. We immobilized monoclonal antibodies on polystyrene microspheres by physical adsorption and found the saturation coverage to be $9 \mathrm{mg} / \mathrm{m}^{2}$. We are presently studying the binding of piliating cells to the immobilized antibodies. Studies with sub-units for pure pili, and piliating cells reveal that the immobilized antibodies have a capacity of binding $1 \times 10^{11}$ piliating cells per $\mathrm{m}^{2}$ of surface area, and that cell binding increases with increasing concentration until saturation occurs, similar to Langmuir adsorption isotherms. 


\title{
AN ADVANCED BIOPROCESSING CONCEPT FOR THE CONVERSION OF WASTEPAPER TO ETHANOL
}

\author{
C.D. Scott, B.H. Davison, B.D. Faison, \\ T.C. Scott, and J. Woodward \\ Oak Ridge National Laboratory \\ Oak Ridge, TN 37831-6226
}

There is an increasing interest in recycling useful components of solid waste material and/or in using certain fractions for production of energy or higher-value materials such as commodity chemicals. The growing availability of segregated waste, frequently at the source, will potentially provide relatively well-defined materials that are prime candidates for other uses. Of particular interest is the availability of large quantities of wastepaper, already segregated, that could be considered as low-cost, perhaps even negative-cost, feed materials for the production of crude sugars and conversion to ethanol.

Advanced concepts should result in potential bioprocessing enhancements that could lead to the economical use of wastepaper as a chemical feedstock. This is particularly true for the enzymatic saccharification of the included cellulose and subsequent conversion of the sugar to ethanol. Specific advances include: an attrition bioreactor with coupled cellobiose conversion and product recovery that would reduce the required residence time for enzymatic saccharification; recovery and recycle of the cellulase enzymes; and use of fluidized-bed bioreactors for the production of the cellulase enzymes, conversion of the sugar to ethanol, and wastewater treatment. There has been preliminary investigation of each of these processing steps on a small laboratory scale. 


\title{
BIOCHEMICAL CONVERSION OF CELLULOSIC BIOMASS TO FUEL ETHANOL IN THE CONTINUOUS OPERATIONAL MODE
}

\author{
G.P. Philippidis, T.K. Smith, and C.E. Wyman \\ National Renewable Energy Laboratory \\ Golden, CO 80401
}

Cellulosic biomass can be converted biochemically to ethanol through simultaneous saccharification and fermentation (SSF). The SSF process combines the enzymatic hydrolysis of cellulose to glucose, catalyzed by cellulase, with the fermentative conversion of glucose to ethanol. Although batch is the most simple and common mode of operation, it may not provide the best means for large-scale production of a commodity chemical, such as ethanol. Operation of the SSF process in a continuous mode is expected to result in better overall ethanol productivity and economics by diminishing the start-up and shut-down time and allowing the system to be maintained in the optimal kinetic regime. The design of a continuous SSF system and its performance with lignocellulosic substrate at steady state in well-mixed stirred tank bioreactors will be discussed. Theoretical studies, based on a formulated deterministic SSF model, and experimental data from the continuous operation will be presented. 
Paper 17

\title{
BIOREACTORS FOR CONVERSION OF PARTICULATE BIOMASS TO ETHANOL: EXPERIMENTAL RESULTS, ANALYSIS, AND DESIGN
}

\author{
C.R. South, D.A. Hogsett, and L.R. Lynd \\ Dartmouth College \\ Hanover, NH 03755
}

The bioreactor is a dominant cost item in process designs for biomass ethanol production with enzymatic hydrolysis. Notwithstanding this importance, the development of quantitative relationships useful in systematic analysis and design of bioreactors for particulate biomass is in a nascent state. In particular, a descriptive rate equation with any degree of generality has not been widely accepted to date.

Recently, South et al. (Submitted to AIChE J.) proposed a rate equation that is successful at predicting conversion vs. reaction time at various enzyme loadings for batch simultaneous saccharification and fermentation (SSF). Morever, the proposed rate equation also predicts continuous SSF results, provided that a particle population model is employed.

After reviewing the development and application of the above rate equation, this presentation will use this analytical framework to explore reactor design issues not considered previously in this context. A variety of reactor types will be compared including batch, continuous well-mixed, and continuous non-well mixed. Experimental results will be presented for both SSF using yeast and fungal cellulase and for direct microbial conversion using $C$. thermocellum. Finally, the adequacy of a vailable analytical models and experimental data for the purpose of design will be evaluated. 


\title{
INTEGRATED PRODUCTION OF ETHANOL FUEL AND PROTEIN FROM COASTAL BERMUDAGRASS
}

\author{
L.B. de la Rosa, V.M. Latimer, S. Reshamwala, and B.E. Dale \\ Texas A\&M University \\ College Station, TX 77843-2476
}

\begin{abstract}
The herbaceous crops which may provide fermentable carbohydrates for production of fuels and chemicals also contain 10-20\% protein. Protein coproduction with biomass-derived fuels and chemicals has at least two important advantages: 1) food and fuel production can be integrated, 2) protein has a high value per unit weight and thus may significantly improve overall process economics. We report here the results of an integrated approach to producing protein and fermentable sugars from one herbaceous species, Coastal Bermudagrass (CBG). The ammonia fiber explosion (AFEX) process is used to increase the reactivity of cellulose and hemicellulose in CBG towards enzymatic hydrolysis. Over $90 \%$ (approximately 650 milligrams reducing sugars/gram dry $C B G$ ) conversion of cellulose and hemicellulose to simple sugars can be achieved at 5 IU cellulase per gram of dry AFEX-treated CBG versus about $15 \%$ conversion for untreated CBG. The AFEX treatment also improves protein extraction from CBG; over $80 \%$ protein recovery is possible from AFEX-treated CBG versus about $30 \%$ recovery from untreated $C B G$. Protein recoveries, amino acid compositions and sugar yields and compositions are reported for several sets of AFEX pretreatment, enzymatic hydrolysis and protein extraction conditions.
\end{abstract}




\title{
ONE-STEP PHOTOCONVERSION OF BIOMASS TO VOLATILE HYDROCARBONS AND MOLECULAR OXYGEN
}

\author{
E. Greenbaum, C.V. Tevault, and C.Y. Ma \\ Oak Ridge National Laboratory \\ Oak Ridge, TN 37831-6194
}

The simultaneous photoevolution of molecular oxygen and volatile hydrocarbons was observed when ferric ions were implanted in wood under high pressure and irradiated with near UV and visible light. Control experiments with pure microcrystalline cellulose and lignin indicated that both of these major components of wood could undergo phototransformation. Additional control experiments with ion-implanted dried samples suggested that the source of oxygen was the substrate material itself rather that the water of the aqueous solution used to impress the ions into the wood fiber matrix. Although hydrocarbon evolution by UV-induced degradation of lignocellulosic materials is well-known, implanting photosensitizing ions increases the yield by more than a factor of 100 . Moreover, the present studies reveal photochemistry with an intriguing formal analogy to normal photosynthesis: an unambiguous endothermic reaction in which hydrocarbons and molecular oxygen are simultaneously photoproduced. This analogy is discussed in the context of oxidationreduction levels of the respective carbon substrates, the source of reductant for the photoredox reactions, and the photophysics and photochemistry of the structured matrices in which the light-induced reactions occur. UV photons are expensive to produce. Therefore, they are presently uneconomical for practical process operations. However, rapid advances in silicon solar cell technology for the production of low-cost electricity may alter the analysis, especially for any additional credits that may accrue to fuels and chemicals produced from renewable resources. 


\title{
EXTRACTIVE RECOVERY OF PRODUCTS FROM FERMENTATION BROTHS
}

\author{
Y.-T. Su, J. Kim, E.L. Lannotti, and R.K. Bajpai \\ University of Missouri-Columbia \\ Columbia, MO 65211
}

Considerations of partition coefficients, selectivity, biotoxicity, and waste generation are important in selection of appropriate solvents to be used for extractive recovery of products from fermentation broths. Several selection criteria can be used based upon the nature of different species present in the broth. These criteria, along with examples of specific case studies, will be presented in this paper. These serve not only in screening of useful solvents, but also in pointing to the specific modes of operation of recovery-coupled bioprocesses. 


\title{
METHODOLOGY FOR EVALUATING THE ECONOMICS OF BIOLOGICALLY PRODUCING CHEMICALS AND MATERIALS FROM ALTERNATIVE FEEDSTOCKS
}

\author{
R. Landucci, B. Goodman, and C. Wyman
}

\author{
National Renewable Energy Laboratory \\ Golden, CO 80401
}

\begin{abstract}
A wide variety of chemicals and materials can be produced through bioconversion. In order to identify the most promising candidates, a three-phased screening approach was developed. Initially, using a Fraction of Revenue for Feedstocks (FRF) methodology, candidates are screened based $o_{11}$ the volumes and yields of products and by-products, and the prices of starting materials. Then, comparisons are made between products from renewable and conventional feedstocks. Finally, an integrated product/process screening provides a detailed estimate of production costs and return on investment.

Using this technique, $\mathbf{4 0}$ potential chemicals and materials from alternative feedstocks were screened to determine near, mid, and long term opportunities for technology development. An overview of this methodology will be provided along with an example of how this tool was applied to evaluate a specific product, succinic acid.
\end{abstract}




\title{
DESIGN OF A COMMERCIAL MUNICIPAL SOLID WASTE TO ETHANOL FACILITY USING A ONE-STAGE DILUTE SULFURIC ACID HYDROLYSIS PROCESS
}

\author{
T.M. Shipley, M.M. Bulls, J.D. Broder, \\ R.O. Lambert, Jr., and J.W. Barrier \\ Tennessee Valley Authority \\ Muscle Shoals, AL 35660
}

In April 1990, the Tennessee Vall:; Authority (TVA), located in Muscle Shoals, Alabama, began a 21/2 year project to produce ethanol from municipal solid waste (MSW) using a one-stage dilutr acid hydrolysis process. The process involves a frontend classification of the MSW to recover recycla 'is and hycirolysis and fermentation of the cellulosic portion of municipal solid waste to produce ethanol. Laboratory analyses were performed using various types of MSW such as newsprint, cardboard, and refuse-derived fuel (RDC) pellets to determine which feedstock produced maximum ethanol yields. Later, tests were performed on a larger scale, 2 tons per day, to determine the accuracy of laboratory results. Based on the findings, as in-' epth plant design was performed for a 2,000 ton per day ethanol-producing facility. Capital aild annual revenue requirements for the facility using a $\$ 45 /$ ton MSW tipping fee were $\$ 195,000,00 C$ nd $\$ 27,000,000$, respeciively. The results of the technical and economic evaluation will be presented. 
Paper 23

\title{
ETHANOL FROM LIGNOCELLULOSIC WASTES WITH UTILIZATION OF RECOMBINANT BACTERIA
}

\author{
R. Katzen ${ }^{\mathrm{a}}$ and D. Fowler ${ }^{\mathrm{b}}$ \\ ${ }^{a}$ Raphael Katzen Associates International, Inc. \\ Cincinnati, $\mathrm{OH}$ \\ ${ }^{b}$ BioEnergy International, L.C. \\ Gainesville, FL
}

This paper will present the advanced technology which has been developed by BioEnergy International of Gainesville, Florida, utilizing novel recombinant strains of bacteria developed by Dr. Lonnie Ingram of the University of Florida. The first commercial applications of these unique fermenting organisms, which convert 5-carbon sugars, as weli as 6-carbon sugars, and oligomers of cellulose (e.g., cellobiose and cellotriose), directly to ethanol. Engineering of the proposed systems, which will be utilized for conversion of agricultural wastes, mixed waste papers, and pulp and paper mill waste in forthcoming commercial installations are now under design. This involves the extensive experience of Raphael Katzen Associates International, Inc. in acid hydrolysis, enzyme production, enzymatic hydrolysis and large-scale fermentation engineering.

Specific examples of this advanced technology will be presented in different applications, namely:

- Conversion of the hemicellulose content of sugarcane bagasse to 5-carbon sugars by mild acid prehydrolysis, folluwed by fermentation of the 5-carbon sugar extract with recombinant E-coli in a ommercial installation soon to be under construction in Brazil. This unique process utilizes the surplus hemicellulose fraction of bagasse not required for steam and power generation to produce ethanol, additional to thiat from the original cane juice, which has been converted by conventional sucrose fermentation to ethanol. The process also recovers and converts to ethanol the majority of sucrose normally lost with the bagasse fibers. Resultant beer is enriched in an innovative process to eliminate the need for incremental rectification capacity.

- Application of this technology to mixed waste paper in Florida, with a high loading of newsprint ( $85 \%$ mechanical wood fiber), will involve a mild acid prehydrolysis, with partial extraction of the 5-carbon sugars produced from hemicellulose as a feedstock for propagation of the recombinant Klebsiela oxytoca bacterium. Included is a facility providing for in-house production of cellulase enzyme, as an active whole broth for direct use in simultaneous saccharification and fermentation of the remaining cellulose and residual 5-carbon sugars to ethanol. This is followed by distillation and dehydration in the advanced commercially-available low energy recovery system.

- Another potential application of this unique technology involves utilization of a variety of wastes from several pulp and paper mills in close proximity, permitting collection of these wastes at : iw cost, and reducing the considerable cost encountered in disposing of such lowenergy wet waste. Based on pilot plant experience with converting such waste by simultaneous enzymatic hydrolysis and fermentation, the same techniques will be applied as in the second case, with use of acid prehydrolysis only if the hemicellulose-derived sugars can be economically recovered. If not, acid hydrolysis will be eliminated and only the simultaneous saccharification and fermentation will be carried out, utilizing in-house produced enzyme broth and recombinant Klebsiela oxytoca. 
Paper 24

\title{
ECONOMICS OF MOLASSES TO ETHANOL IN INDIA
}

\author{
S. Inamdar \\ PRAJ Conseltech PVT. LTD. \\ Pune 411 004, India
}

India is one of the largest producers of ethanol from sugarcane molasses. Various chemicals, including many which are usually derived based on petrochemical route, are produced from this agro-based resource.

Characteristics of molasses available are presented. Methods used for conversion of molasses to ethanol are presented. Costs of plant and machinery and projects for molasses to ethanol are presented.

Based on prevailing costs of inputs like raw materials, steam, electricity, and labor, variable cost of production is presented. Based on capital cost of project for production of ethanol as well as for treatment of effluent slops, cost of capital overhead like interest and depreciation is presented. Method of treatment of effluent has a significant effect on cost of production.

Demand from international markets and pattern of local usage will decide economics in the future. At present, cost of production of ethanol works out to $\$ 0.15$ to $\$ 0.25$ per litre of $95 \%$ ethanol, including capital overheads. This makes it a very competitive source of raw material to produce various chemicals.

Relative weightage of various components of cost like raw materials, energy, labor, and capital costs will be presented for comparison with international scenario. 


\title{
BIOMASS REFINERIES: RENEWABLE RESOURCES FOR PRODUCTION OF ADVANCED MATERIALS, SPECIALTY CHEMICALS AND FUELS
}

\author{
L. Davis Clements \\ USDA-CSRS Office of Agricultural Materials \\ Washington, DC 20250-2200
}

The traditional focus of agriculture has been defined as the production of food, feed and fiber for human use. This approach is too restrictive. A less limiting paradigm for agriculture is that it is the sustainable production of renewable chemical resources for human use.

Biomass resources are the primary world resource for organic carbon compounds. Our traditional non-food uses for these materials as fiber and fuel have neglected the rich complexity present in the materials.

This talk describes the concept of the biomass refinery, where biomass materials are sources of fermentable sugars, fats and oils, proteins, and natural products. The families of products derived from these resources are outlined using examples of development of biodegradable polymers, engineering plastics and fermentation ethanol.

The USDA program in development of new industrial uses for agricultural products and new initiatives within the program will be highlighted. 
Paper 26

PRODUCTION OF 1 4-BUTANEDIOL FROM SUCCINIC ACID

\author{
W. Walker \\ John Brown Engineering and Construction \\ Chicago, IL 60606
}

Davy McKee Process Technology has developed and commercialized a new process for the conversion of Maleic Anhydride to 1,4-butanediol. The process could be adapted to utilize succinic acid as a feed stock derived from bio-technology sources. Initial laboratory test work has confirmed the technical feasibility of the route. This paper examines the issues that determine the overall viability of the process. The technical and economic impact of feed stock changes on the butanediol flow sheet is reviewed and the constraints on an acceptable succinic acid feed stock established. These parameters are then used to define the product quality and cost targets which must be achieved by any succinic acid production route to be commercially viable. 
Paper 27

PRODUCTION OF LACTIC ACID FROM RENEWABLE RESOURCES

\author{
J. K. Brooks \\ John Brown Engineering and Construction \\ Chicago, IL 60606
}

Unavailable at time of printing 


\title{
BIOLUMINESCENT REPORTER BACTERIA DETECT CONTAMINANTS IN SOIL SAMPLES
}

\author{
R.S. Burlage ${ }^{a}$, A.V. Palumbo ${ }^{a}$, A. Heitzer ${ }^{b}$, \\ and G. Sayler \\ ${ }^{a}$ Oak Ridge National Laboratory \\ Oak Ridge, TN 37831-6036 \\ bUniversity of Tennessee \\ Knoxville, TN 37996
}

Reporter strains of bacteria were tested using soil samples from several sites near a leaking fuel oil storage facility. The reporter bacteria utilized the bioluminescent lux genes from Vibrio fischeri, which were transcriptionally fused to catabolic gene sequences. The catabolic genes of interest specified the degradation of toluene (from the TOL plasmid) and napthalene (from the NAH7 plasmid and from a NAH plasmid recently isolated. The former reporter strain was able to detect toluene and $0, \mathrm{~m}$. and $\mathrm{p}$-xylene, while the latter strain could detect napthalene and salicylate.

Soil slurries were made from $2 \mathrm{~g}$ samples of the test soils, and were then incubated with one of the bacterial cell suspensions in a small vial. Light production from these vials was checked periodically for three hours after addition, and the results were compared to positive controls to determine whether a significant level of specific contaminant was present in that sample. The results suggested that two soil samples were contaminated with both toluene (or xylene) and napthalene. These data were useful in describing a contaminant plume. Uncontaminated samples that were mixed with a specific contaminant also demonstrated a positive response from these reporter bacteria. 


\title{
A FIELD-SCALE DEMONSTRATION OF A NOVEL BIOREMEDIATION PROCESS FOR MGP SITES
}

\author{
V.J. Srivastava ${ }^{a}$, R.L. Kelley ${ }^{a}$, J.R Paterek ${ }^{a}$, T.D. Hayes ${ }^{b}$, \\ S. Nelson ${ }^{c}$, and J. Golchin ${ }^{d}$

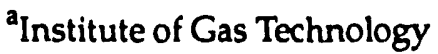 \\ Chicago, IL 60616 \\ ${ }^{b}$ Gas Research Institute \\ Chicago IL 60616 \\ ${ }^{c}$ Midwest Gas Company \\ Sioux City, IA 51101 \\ dState of lowa, DNR \\ Ames, LA 50010
}

The Institute of Gas Technology (IGT) has developed and demonstrated an integrated chemical-biological treatment (CBT) process to efficiently remediate soils and sludges contaminated with hazardous compounds such as polynuclear aromatic hydrocarbons (PAHs), volatile hydrocarbons (e.g., BTEX), and polychlorinated biphenyls (PCBs). Bench-scale studies as well as the field-scale tests show that the CBT process is effective in significantly enhancing the rate as well as the extent of degradation of these contaminants.

This paper will present the results of bench-scale tests conducted with a variety of PAHs and PCBs contaminated soils and a set of field-scale tests conducted with soils from a former manufactured gas plant (MGP) site (now a Superfund site) that contained coal-tar associated PAHs. The field tests results show that the chemically enhanced bioremediation using the CBT Process results in up to $90 \%$ improvement over conventional bioremediation for total PAHs (2-6 ring compounds) degradation and over $100 \%$ improvement over conventional bioremediation for carcinogenic PAHs (4-6 ring compounds) degradation. The paper will also discuss the preliminary results of the second field test being conducted using the contaminated soils from another MGP site. 


\title{
CHARACTERIZATION AND BIOTREATABILITY OF PETROLEUM CONTAMINATED SOILS IN A CORAL ATOLL IN THE PACIFIC OCEAN
}

\author{
R.L. Siegrist ${ }^{a}$, T.J. Phelps ${ }^{a}, b$, N.E. Korte ${ }^{a}$, D.A. Pickering ${ }^{a}$, \\ R. Mackowski ${ }^{\mathrm{a}}$, L.W. Cooper ${ }^{\mathrm{a}}$ \\ aak Ridge National Laboratory \\ Oak Ridge, TN 37831-6038 \\ ${ }^{b}$ University of Tennessee \\ Knoxville, TN 37932-2567
}

On islands in the Pacific Ocean, soils have become contaminated by petroleum hydrocarbons as a result of power plant operation and aircraft and ship refueling activities. On Kwajalein Island, a US Army facility in the Republic of the Marshall Islands, studies were conducted to assess the potential for bioremediation of diesel fuel contaminated soils. Treatability studies were conducted on the Island and in laboratories in Oak Ridge, TN. Analyses included soil contamination levels, nutrient content, microbial densities, and biodegradation potential. Onsite and laboratory respirometric experiments evaluated $\mathrm{O}_{2}$ uptake, $\mathrm{CO}_{2}$ evolution and $\mathrm{C}$ isotopic composition. The soils on Kwajalein Island were coral-derived sands, alkaline, and nutrient deficient. Diesel fuel contamination (TPH) ranged from below detection limits to $50,000 \mathrm{mg} / \mathrm{kg}$, with the highest levels in the capillary fringe and the upper saturated zone. Microorganisms were present at $10^{3}$ to $10^{6} / \mathrm{g}$. Biodegradation of fresh diesel fuel added to previously uncontaminated coral sand was degraded very slowly ( $\mathrm{mg} \mathrm{TPH} \mathrm{kg}^{-1} \mathrm{~d}^{-1}$ ). Biodegradation of weathered diesel fuels in contaminated soils was also slow $\left(\mathrm{mg} \mathrm{TPH} \mathrm{kg} \mathrm{d}^{-1}\right.$ ). Nutrient additions enhanced biodegradation rates 2 fold. Biodegradation of diesel fuel added to previously contaminated soils supplemented with nutrients proceeded at $20 \mathrm{mg} \mathrm{TPH} \mathrm{kg} \mathrm{d}^{-1}$. It was concluded that bioremediation of petroleum contaminated soils by indigenous microorganisms was feasible and that biodegradation rates could be enhanced up to an order of magnitude by the addition of nutrients. This paper describes a multi-disciplinary approach to assessment of bioremediation potential at remote sites and highlights the methods and results of analyses and experiments on Kwajalein Island. 
Paper 31

\title{
ALTERNATING EXTRACTION/INJECTION WELL INTERACTIONS FOR IN SITU BIOREMEDIATION
}

\author{
M.S. Shouche ${ }^{a}$, J.N. Petersen ${ }^{a}$, R.S. Skeen ${ }^{b}$, and B.H. Hooker ${ }^{c}$ \\ ${ }^{a}$ Washington State University \\ Pullman, WA 99163 \\ ${ }^{\text {b }}$ Battelle Pacific Northwest Laboratories \\ Richland, WA 99352 \\ 'Tri-State University \\ Angola, IN 46703-0307
}

Liquid wastes containing radioactive, hazardous, and regulated chemicals have been generated throughout the $40+$ years of operation at the U.S. Department of Energy (DOE) Hanford Site. In situ bioremediation is one technology currently being developed at Hanford to meed the need for cost-effective technologies to clean groundwater contaminated with $\mathrm{CCl}_{4}$, nitrate, and other organic and inorganic contaminants. The success of in situ biological destruction depends on the distribution of the microorganisms through the flow field to be remediated. Previous studies have shown that higher microbial cell concentration near the nutrient injection point can lead to pore plugging which, in turn, leads to poor nutrient transport and will eventually render the well useless. Here, a new nutrient feeding strategy is developed which causes the biomass to grow in a more uniform fashion throughout the flow field. In this case, the biomass does not tend to be concentrated only near the injection well. This is achieved by pulsing the nutrients at each end of the well, changing the flow direction through the flow field at regular intervals and internally recycling the nutrients and contaminants. This feeding strategy helps extend the life of the remediation system and increases the degradation of $\mathrm{CCl}_{4}$. This paper deals with the optimum nutrient feeding strategy for such a system using a predictive simulation. 
Paper 32

\title{
LANDFILL MANAGEMENT FOR METHANE GENERATION AND EMISSION CONTROL
}

\author{
D. Augenstein \\ 4277 Pomona Ave. \\ Palo Alto, CA 94306
}

Methane emissions from landfills in the U.S. alone are estimated to add the order of $1 \%$ to $2 \%$ to the annual increase in radiative forcing due to atmospheric buildup of all greenhouse gases. To abate emissions, landfills could be managed as bioreactors to increase rates and yields of methane generation and designed to maximize gas recovery. "Controlled landfills" would be by some standards the world's largest managed fermentation bioreactors, and could have a significant mitigating effect on global warming. Necescary mass transfer would need to occur in a high solids environment, under circumstance of low water activity/matric potential. Temperature dependence of rate (about $15 \mathrm{Kcal} / \mathrm{mole}$ ), and the potentially very slow conductive dissipation of the heat of methanogenesis (also about $15 \mathrm{Kcal} / \mathrm{mole}$ ) at landfill dimensions make means for adding or removing heat highly important. Field demonstrations have given results in some cases explainable in retrospect, but in other cases puzzling, and a number of rate control, technical, and regulatory issues remain to be resolved. This presentation will review technical issues, history of enhancement efforts to date, and possible explanations for some of the observed results. Issues, such as amendments (nutrients, buffers), inocula, as well as economic and regulatory aspects, will be discussed. A forthcoming demonstration project in California will be reviewed. 


\title{
FULL-SCALE FIELD TEST OF A MICROBIAL SULFIDE OXIDATION PROCESS IN AN OIL FIELD SOUR WATER RETENTION POND
}

\author{
K. Raterman ${ }^{a}$, K.L. Sublette ${ }^{b}$ and P.T. Selvaraj ${ }^{b}$ \\ ${ }^{a}$ Amoco Production Co. \\ Tulsa, OK 74103 \\ bUniversity of Tulsa \\ Tulsa, OK 74104
}

The ability of the chemoautotroph and facultative anaerobe Thiobacillus denitrificans to deodorize and detoxify a sour oil field produced water has been evaluated under simulated field conditions. A sulfide-tolerant strain of $T$. denitrificans has been used to remove inorganic sulfide from a synthetic sour brine containing $400 \mathrm{mg} / \mathrm{L}$ total dissolved solids (TDS) and $100 \mathrm{mg} / \mathrm{L}$ sulfide. The sour brine was treated continuously in a rectangular plugflow reactor which approximated the scaled dimensions of a field crude oil skimmer pond at an Amoco Production Co. Salt Creek Field site in Wyoming. The head space of the reactor was purged with $\mathrm{N}_{2}$ in order to capture $\mathrm{H}_{2} \mathrm{~S}$ off-gases in a zinc acetate trap. Brine was fed to the reactor continuously for 90 days at rates corresponding to residence times of $0.17-6$ days. Temperature and $\mathrm{pH}$ ranged from $22^{\circ}-40.5^{\circ} \mathrm{C}$ and $7.5-8.8$, respectively. The start-up biomass concentration was approximately $100 \mathrm{mg} / \mathrm{L}$. No additional $T$. denitrificans biomass was added to the reactor after start-up.

At residence times of 0.3 days and greater inorganic sulfide was undetectable in the effluent. No $\mathrm{H}_{2} \mathrm{~S}$ was detected in the outlet gas or the zinc acetate trap. Approximately $80 \%$ of the sulfide feed was oxidized to sulfate and removed from the reactor in the liquid effluent. The remainder was partially oxidized to elemental sulfur which was retained in the reactor.

The oxidation of inorganic sulfides by $T$. denitrificans represents a viable process concept for the treatment of sour water co-produced with oil and gas. A full-scale field test of this process in an Amoco Production Co. sour water retention pond in the Salt Creek Field in Wyoming is ongoing at the time of this writing. The $19,000 \mathrm{bbl}$ pond receives a feed of $6000-7000 \mathrm{bbl} / \mathrm{d}$ of produced water containing $100-110 \mathrm{mg} / \mathrm{L}$ sulfide. Since inoculating the pond with 20-30 lb of flocculated $T$. deritrificans biomass, sulfides in the pond have been reduced to undetectable levels and odors eliminated. A description of the field test methodology and results will be presented. 


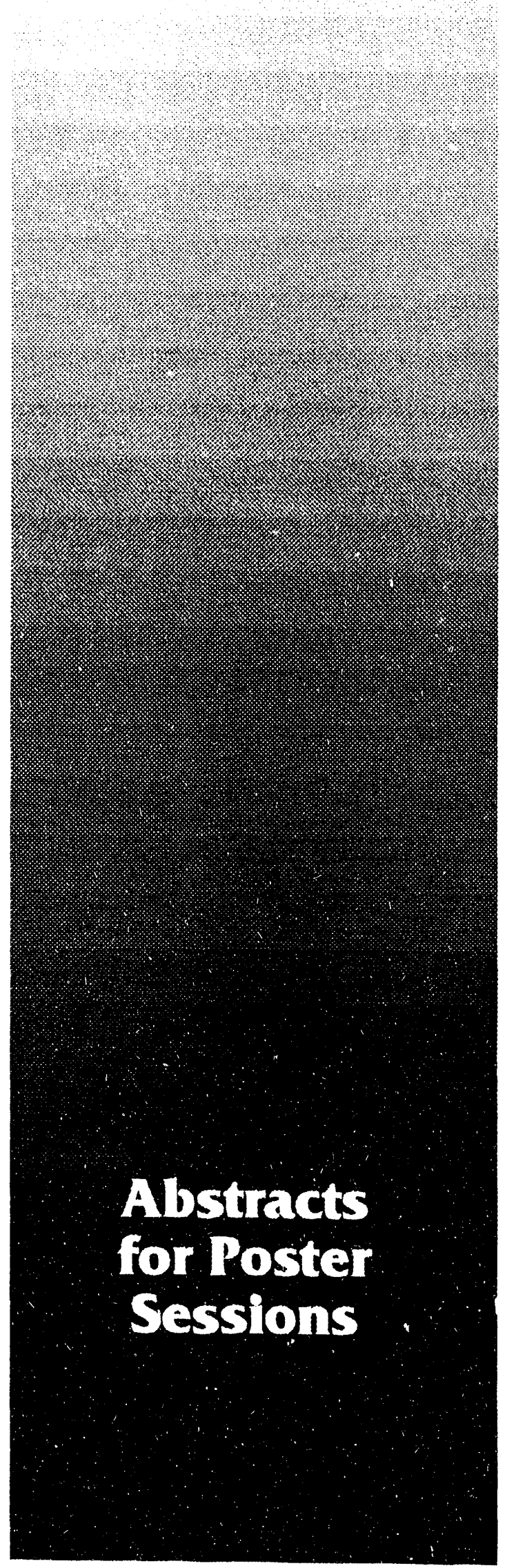




\title{
CRITICAL REACTIONS IN RIPENING OF CHEESES: A KINETIC ANALYSIS
}

\author{
J. Kim, M. Starzak, G.W. Preckshot, and R.K. Bajpai \\ University of Missouri-Columbia \\ Columbia, MO 65211
}

\begin{abstract}
A mathematical model has been developed for the key reactions taking place in the process of cheese ripening. The intracellular peptidases released through cell-lysis during ripening was found to have the most profound effect upon cheese flavor. The time required for ripening of cheeses can be significantly reduced by carefully controlling the cell numbers at the beginning of cheese ripening and their dipeptidase activity. In the selection of appropriate starter culture, it is important to select strains with specified rates of lysis, and that release large amounts of dipeptidases with low degradation rates upon lysis.
\end{abstract}




\title{
DESIGN AND INSTALLATION OF THE NREL BIOMASS-TO-ETHANOL PKOCESS DEVELOPMENT UNIT
}

\author{
D. Schell, B. Duff, and P. Bergeron \\ National Renewable Energy Laboratory \\ Golden, CO 80401
}

The U.S. Department of Energy (DOE) and the National Renewable Energy Laboratory (NREL) are installing a Process Jevelopment Unit (PDU) for the conversion of biomass to ethanol. It will serve as a user facility where private industry, academia, and government can cooperatively develop biomass conversion technology. The PDU will be able to verify process performance, investigate alternative process options, and develop scale-up data for design of large scale demonstration or commercial facilities. The following major unit operations are included in the process design: feedstoch preparation, pretreatment, fermentations, and ethanol recovery. The plant will be designed to process $1.0 \mathrm{dry}$ ton/day of biomass and will be flexible enough to accommodate a variety of process conditions and feedstocks.

A subcontract has been placed with John Brown Engineering and Construction for Phase I design of the pilot plant. This effort invo!ves vend-r testing of critical equipment, a conceptual process design, ordering of long lead-time equipment, and preliminary engineering. The conceptual design was completed at the end of October 1993 and preliminary engineering is scheduled to be completed by the end of February 1993. At the end of Phase I, another subcontract will be placed for Phase II, detailed design and installation of the PDU. The unit is expected to begin start-up operation in early 1994. 


\title{
FIELD TESTING OF INDIRECT GASIFICATION OF BIOMASS FOR SYNGAS PRODUCTION
}

\author{
K. Durai-Swamy and B. Aghamohammadi \\ MTCI, Inc. \\ Santa Fe Springs, CA 90670
}

Field testing of the MTCl gasifier using biomass feedstock is being carried out at the gasification plant at Ontario, California. The gasifier employs a novel indirect heating method using a pulse combustor fired either with natural gas or process fuel gas. This rasification produces medium-Btu process gas which can be used for combined cycle power generation as well as for production of syngas. The tests will be performed as steady state conditions using two types of feeds, namely a woody feed such as bark and a herbaceous feed such as rice husk. The tests will be carried at a range of temperatures and steam rates to determine the process yield as a function of these parameters. 


\title{
AN IMPROVED PROTOTYPE APPARATUS AND PROCESS FOR SEPARATLNG CELLULOSIC MATERIALS FROM MUNICIPAL SOLID WASTE
}

\author{
M.H. Eley \\ Department of Biological Sciences and K. E. Johnson Research Center \\ The University of Alabama in Huntsville \\ Huntsville, AL 35899
}

The original prototype process unit for demonstrating steam classification of municipal solid waste (MSW) (U.S. Patent Nos. 4,342,830 and 4,540,495) was found to be unsuitable for scale-up to commercialize the process. With the objective of commercial scale-up, an improved prototype process apparatus has been fabricated and tested, which has led to a number of improvements in the entire process. The new unit has a capacity per unit volume for MSW that is twice the previous unit, but the new unit can be loaded to capacity in less time. The new unit has superior mixing and steam injection features that have shortened the total process time by $30 \%$, that have reduced the previously required moisture addition by $5 \mathrm{c} \%$ or more, and that have reduced the previous energy requirement for steam by at least $30 \%$. The recovered recyclables are higher quality, and the cellulosic product is more suitable for combustion, composting, or as a feedstock for biological or chemical conversion to fuels and chemicals. Design features and operating parameters for the new unit will be presented along with data showing the improvements in the process and cellulosic product. 


\title{
MICROBIAL LIQUEFACTION OF LIGNITE PRETREATED WITH DILUTE ACID AT ELEVATED TEMPERATURE AND PRESSURE
}

\author{
H. Huckabay, A. Rao, A. Maxey, and B.B. Elmore \\ Louisiana Technical University \\ Department of Chemical Engineering \\ Ruston, LA 71272
}

\begin{abstract}
In recent years, much attention has been given to the ability of microorganisms to modify or degrade lower rank coals. The presence of large lignite deposits at depths which cannot be economically mined serves as an impetus for further investigation into possible in situ biliquefaction and recovery. Numerous researchers have shown the increased susceptibility of lignite to microbial attack when pretreated with various chemical agents. Here, an investigation has been made into the ability of several cultures to liquefy lignite samples which have been pretreated with very dilute acid solutions at elevated temperatures and pressures. Coal samples have been treated in batch cultures and in cell-free broth extracts. ML-13 (a Candida sp.) and LSC (a raw isolate), both obtained from the University of Arkansas, have each shown an ability to significantly liquefy samples of lignite obtained from Louisiana deposits.
\end{abstract}




\title{
BURIED OIL RECOVERY WITH THE HELP OF POLYSACCHARIDE ETHAPOLAN
}

\author{
T.A. Grinberg, S.A. Vlasov, T.P. Pirog, and Y.R. Malashenko \\ Ukrainian Academy of Sciences \\ Zabolotny Institute of Microbiology and Virology \\ 252143, Kiev, The Ukraine
}

Microbial exopolysaccharide (ethapolan) is obtained by the method of microbiological synthesis. It contains residues of neutral sugars: glucose, galactose, and mannose etherified by fatty acid residues (C12-C18). Acidic groups in its content are represented by pyruvic and uronic acids. Ethapolan forms highly viscous solutions with concentrations of $0.1-0.01 \%$. The production of ethapolan has a number of definite advantages as compared to that of xanthan - commercially recognized microbial exopolysaccharide. For example, ethanol used as its production source is not a food staff. Ethapolan solutions have higher viscosity meanings than xanthan (Sigma) has, thus, characteristic viscosity of ethapolan is $11,000 \mathrm{ml} / \mathrm{g}$ and kinetic viscosity of its $0.1 \%$ solution is $5.75 \mathrm{cSt}$ while these of xanthan are $650 \mathrm{ml} / \mathrm{g}$ and 3,65 correspondingly. Ethapolan has a unique property: viscosity of its water solutions grow considerably at a shift down.

The strain - producer of ethapolan is not pathogeneous. Ethapolan is biologically stable and is not toxic.

Gelforming formulae and compositions developed basing on ethapolan were used for water inflows isolation in drained out oil wells of an oil field in the Ukraine. All the ethapolan treated oil wells gave stable oil recovery increase during the next year.

Some of the polysaccharide compositions can be applied at high, up to $130^{\circ} \mathrm{C}$, oil-pool temperature meanings and the profile water mineralization up to $200,000 \mathrm{ppm}$.

Ethapolan can also be used in industry for food and perfumery production, as a concrete plasticizer in building construction, and as a foaming agent (to fight fire) in mining. 


\title{
ANAEROBIC DOWNFLOW STATIONARY FIXED FILM REACTOR: EARLY STARTUP WITH DAIRY WASTEWATER
}

\author{
N. Mehadia and A.O. Ingle \\ Post Graduate Teaching Department \\ Microbiology, L.I.T. Premises \\ Nagpur University \\ Nagpur 440010 India
}

\begin{abstract}
All industries discharging wastewater into municipal sewage systems are asked for pre-treatment of their wastewater to control pollution problems. Conventional aerobic treatment processes are not economical therefore, anaerobic processes has gained importance. Food industries can achieve suitable processes by maintaining quality of effluent by anaerobic treatment. The process has an advantage of biogas generation which can be used as fuel in the same industry for heating purpose in boilers and pasteurisation units, etc.
\end{abstract}

As anaerobic treatment process takes long start up period, the paper deals with the study to reduce the start up period with Dairy Wastewater (DWW) by fixed film reactor for biogas production. In dairy industry (cheese making, caesin factories, etc.) startup has lasted about as long as for wine distilleries which takes at least six to eight months. However, the process can probably be reduced to less than six months if improvement can be made during startup and thus to evaluate the capacity of DWW for microbial methanation by Downflow Stationary Fixed Film (DSFF) reactor. DWW being combined effluent is a composite waste containing carbohydrates, proteins and fats.

Burnt brick pieces as support shows high porosity and irregular shape with sheltered regions for microbial colonisation and biofilm growth. It's biologically inert, mechanically stable and cost per unit volume is also low. DWW contain lactose in high quantity so doesn't need supplementation for early startup. Similarly, trace elements requirement ( $\mathrm{Ni}, \mathrm{Co}, \mathrm{Fe}$ and $\mathrm{Mo}$ ) is also fulfilled with even dilute $\mathrm{DWW}$.

Startup was initiated at room temperature $\left(34^{\circ} \mathrm{C}\right)$ with 39 days hydraulic retention time (HRT) and gradually decreased to 0.38 days over a total period of two months. The rumen fluid which has broad range of methonogenic flora was used as inoculum.

At 39 days HRT, OLR was $0.069 \mathrm{Kg}$ COD m $\mathrm{m}^{-3} \mathrm{~d}^{-1}$ where gas production was $0.130 \mathrm{~m}^{3} \mathrm{Kg}^{-1} \mathrm{COD} \mathrm{d}$. Finally, within two months startup the reactor was at two days HRT at OLR $0.28 \mathrm{Kg} \mathrm{COD} \mathrm{m}^{-3} \mathrm{~d}^{-1}$ and gas yield was $0.598 \mathrm{~m}^{3} \mathrm{Kg}^{-1} \mathrm{COD} \mathrm{d}^{-1}$. The reactor showed good buffering capacity. The maximum COD removal of $90 \%$ was observed. Methane percent in biogas was constantly between 85 to 90 . 


\title{
FUEL AND ENERGY CRISIS, BURIED OIL, AND MICROBIOLOGY
}

\author{
Y.R. Malashenko, T.A. Grinberg, and S.A. Vlasov \\ Ukrainian Academy of Sciences \\ Zabolotny Institute of Microbiology and Virology \\ 252143, Kiev, The Ukraine
}

Not more than $30 \%-60 \%$ of oil deposited in an oilfield is commonly got out by using the existing means of oil recovery. At present, there is a great number of depleted oilfields all over different continents, the residual oil content (buried oil) of which amounts to just the $30 \%-60 \%$ aforementioned. With certain reservations, the buried oil can be regarded as a strategic fuel and energy reser. e given as "a gift" to the present generation by the oil industry workers, who have not had the proper technologies of the buried oil recovery at their disposal.

Therefore, the development of the buried oil recovery technology will help, say, for some 50 years at least, to do away with the fuel and energy crisis.

Physical, chemical and biological methods are used for the buried oil recovery. Priority among them should be given to biological methods as being highly effective and ecologically clean. One can hope that complex application of all the three trends would make the buried oil complete recovery possible.

Microbial exopolysaccharide (EPS) ethapolan was synthesized and applied as a means of increasing the oil recovery of the depleted oil wells of gas and oil field in Pryluki (the Ukraine). The steady increase in oil recovery has been achieved. By many of its technological properties, ethapolan exceeds xanthan. The determined price of ethapolan is $\$ 28$ per tonne. The mobil plant for ethapolan synthesis in the close vicinity of the producing oil well is developed. Ethapolan is synthesized on ethanol or associated gas as the carbon source. 
Poster 9

\title{
PERFORMANCE AND EMISSION CHARACTERISTICS OF A DIESEL ENGINE OPERATING ON A SAFFLOWER SEED OIL METHYL ESTER
}

\author{
A. Isigigur, F. Karaosmanoglu, and H.A. Aksoy \\ Chemical Engineering Department \\ Istanbul Technical University \\ 80626 Maslak, Istanbul, Turkey
}

Due $w$ their high viscosity which leads to excessive carbon deposits on the injection nozzles and in the combustion chamber, vegetable oils are not suitable for use in modern Diesel engines in their pure form. It is known that the perform cinice of a direct injection Diesel engine is greatly affected by the injection and spray characteristics. Fuel atomization and mixing in the combustion chamber are directly influenced by the viscosity of the fuel injected. Conversion of vegetable oils to fatty esters through transesterification process is an effective way of eliminating the high viscosity problem. This study focused on the evaluation possibilities of safflower seed oil methyl ester as a diesel fuel substitute. Kinematic viscosity and ASTM fuel properties of the methyl ester fuel were within the limits specified for Grade No.2-D diesel fuel. Engine tests were performed on a four cylinder, direct injection $\mathrm{CI}$ engine using methyl ester and reference diesel fuel; engine performance and exhaust emission characteristics were determined. Safflower seed oil methyl ester revealed similar engine performance characteristics as the reference diesel fuel. Lower $\mathrm{CO}$ and EC emissions were obtained when methyl ester was used and significant decreases in particulate emissions were achieved. Negligible amount of sulphur content was an additional advantage of methyl ester over diesel fuel. 


\title{
METHYL ESTER FROM SAFFLOWER SEED OIL OF TURKISH ORIGIN AS A BIOFUEL FOR DIESEL ENGINES
}

\author{
A. Isigigur, F. Karaosmanoglu, and H.A. Aksoy \\ Chemical Engineering Department \\ Istanbul Technical University \\ 80626 Maslak, Istanbul, Turkey
}

Supply-demand imbalances in the energy sector and predicted depletion of conventional fossil-derived fuels stimulated interest and research in the field of fuel alternatives of new and renewable origin. Among the new-renewable energy sources, biomass potential is particularly attractive since its availability is unlimited compared to fossil resources. The majority of investigations have concentrated on vegetable oils and their derivatives as they seem to have the potential to be used as fuel altematives for diesel engines. The primary problems associated with the use of pure vegetable oil as a fuel in compression ignition (Diesel) engines are caused by high fuel viscosity. Transesterification of the oil with short chain alcohols (such as methanol or ethanol) to corresponding fatty esters is the most promising solution to the high viscosity problem. In this work, transesterification method was applied to crude safflower seed oil of Turkish origin using methanol. The variables affecting the monoester yield such as: (1) molar ratio of alcohol to vegetable oil, (2) reaction temperature and duration, (3) type and amount of catalyst used were investigated. In the presence of KOE as the reaction catalyst, $97 \%$ ester yield was achieved with 16 minutes using 1:7 vegetable oil - alcohol molar ratio. A significant improvement was observed in viscosity and other physical properties with the ester product compared to the parent oil. ASTM fuel properties of the methyl ester product were in accordance with those obtained for commercial Grade No.2-D diesel fuel. 
Poster 11

\title{
SIMULATION OF A MODIFIED PERCOLATION PROCESS IN DILUTE-ACID HYDROLYSIS OF BIPHASIC HEMICELLULOSE
}

\author{
B.J. Kim , Y.Y. Lee, and R. Torget ${ }^{b}$ \\ "Auburn University \\ Auburn, AL 36849 \\ ${ }^{b}$ National Renewable Energy Laboratory \\ Golden, $\mathrm{CO} 80401$
}

Acid-catalyzed selective hydrolysis of hemicellulose from cellulosic biomass in general follows a parallel-serial type reaction pattern due to the biphasic nature of the substrate. The kinetic parameters of this reaction were experimentally determined and incorporated into simulation of percolation reactor. Various modification of the reactor operation was implemented to improve the reactor performance focusing on the product yicld. In so doing, a theoretical basis for the need of non-uniform temperature policy was established. As one of such cases, it was proven that step change of reaction temperature during percolation process is advantageous especially in improving the sugar yicld. The yield improvement due to temperature step-change was about $3 \%$ over that of uniform temperature operation. Further refinement of the simulation with regard to the flow rate in the reactor (along with the temperature) has given additional $0.5 \%$ yield improvement. The most significant improvement was seen with application of two-stage reverse-flow reactor arrangement with temperature change (design concept originally developed at NREL). Use of this reactor scheme has given additional $5 \%$ improvement of product yield over that of best case percolation performance with temperature step-change. The reactor simulation was further enhanced taking intraparticle diffusion and axial dispersion into consideration. The effects of these non-ideal reactor behaviors were assessed in relation with the reactor performance. 


\title{
RECOVERY OF LACTIC ACID BY ADSORPTION: RESIN EVALUATION
}

\author{
R.L. Evangelista ${ }^{a}$ and Z.L. Nikolov ${ }^{a, b}$ \\ ${ }^{a}$ Department of Food Science and Human Nutrition \\ bepartment of Agricultural and Biosystems Engineering \\ Iowa State University \\ Ames, IA 50010
}

\begin{abstract}
Adsorption is a process well-suited for the recovery of substances produced in dilute concentration and complex aqueous solution such as fermentation broth. At present, the role of adsorbents in the manufacture of lactic acid is mainly for demineralization of process water and thin crude lactic acid. The main goal of our research is to investigate the use of adsorbents as a primary step in the recovery of lactic acid from fermentation broth. This paper presents the results of ongoing studies on resin evaluation and selection.
\end{abstract}

Basic anion exchange resins with imidazole, pyridine, and amine functional groups were evaluated for capacity and affinity for lactic acid. Composite adsorption isotherms were developed by batch adsorption using aqueous lactic acid solutions having concentrations ranging from 2.5 to $150 \mathrm{mg} / \mathrm{mL}$. Breakthrough curves were obtained by using aqueous lactic acid solution of different $\mathrm{pH}$ levels and fermentation broth of Lactobacillus delbrueckii. Adsorption capacities and association constants were determined. These parameters, as well as the effect of $\mathrm{pH}$ on capacities, will be presented. 


\title{
SYNTHESIS GAS AS SUBSTRATE FOR BIOLOGICAL FUELS AND CHEMICALS PRODUCTION
}

\author{
J.R. Phillips, E.C. Clausen, and J.L. Gaddy \\ Department of Chemical Engineering \\ University of Arkansas \\ Fayetteville, AR 72701
}

Synthesis gas provides a simple substrate for the biological production of fuels and chemicals. Synthesis gas can be produced via established technologies from a variety of feedstocks including coal, wood, and agricultural and municipal wastes. The gasification is thermally efficient and results in complete conversion of the feedstock to fermentable substrate. A number of bacteria have been found to grow autotrophically on the synthesis gas components, carbon monoxide, hydrogen, and carbon dioxide. These bacteria grow and produce acetic acid with synthesis gas as the sole source of energy and carbon. Among them, Clostridium ljungdahlii also produces ethanol. Growth and production by $C$. ljungdahlii have been examined for carbon monoxide, and for hydrogen with carbon dioxide in mineral medium. The thermochemistry of the fermentation reactions, the acetogenic pathway, the nutritional requirements of the organism, and implications for process design are considered. 


\title{
MILLING OF LIGNOCELLULOSIC BIOMASS: RESUITS OF PILOT SCALE TESTING
}

\author{
D. Schell ${ }^{\mathrm{a}}$ and C. Harwood ${ }^{\mathrm{b}}$ \\ ${ }^{a}$ National Renewable Energy Laboratory \\ Golden, CO 80401 \\ bJohn Brown Engineering and Construction \\ Chicago, IL 60606
}

Ethanol is being considered as an attractive alternative transportation fuel for the future and one method of producing large quantities of ethanol is from the conversion of lignocellulosic biomass. One method of conversion involves reducing the size of biomass to smaller particles, which are then treated to hydrolyze the hemicellulosic fraction of the biomass to xylose and increase the susceptibility of the cellulosic fraction to enzymatic hydrolysis. Then in another step, the cellulose is enzymatically hydrolyzed to glucose. Both xylose and glucose can then be fermented to ethanol using a variety of microorganisms. The size reduction step is necessary to eliminate mass and heat transfer limitations during the hydrolysis reactions. However, milling to small size consumes large amounts of power and reducing the power requirements is critical to the overall economics of the process. In this study, the power requirements and size distribution for milling of several biomass feedstocks were determined on a variety of pilot-scale size reduction equipment. Tests were conducted on a variety of disc refiners at Andritz Sprout-Bauer, an air-swept hammer mill at ABB Raymond, and a shredder at MAC Corporation. 


\title{
WHEAT AS A FEEDSTOCK FOR FUEL ETHANOL
}

\author{
K. Sosulski ${ }^{\mathrm{a}}$ and F. Sosulski ${ }^{\mathrm{b}}$ \\ ${ }^{\text {a}}$ Saskatchewan Research Council \\ Saskatoon, Saskatchewan, Canada S7N 2X8 \\ ${ }^{b}$ Department of Crop Science \\ University of Saskatchewan \\ Saskatoon, Saskatchewan, Canada S7N OWO
}

The fuel ethanol plants in the United States operate almost exclusively on corn feedstock. Corn is not available, though, in Western Canada and fuel cthanol plants here utilize wheat and barley. Both grains are 10-15\% lower in starch than corn, which increases the costs of ethanol production. New cultivars of Canadian Prairie Spring wheats are being developed with 5\% more starch and less protein, than durum and bread wheats, to provide an industrial feedstock for ethanol plants. Also, grain pre-processing techniques are being investigated to enhance starch concentration of wheat feedstock of $70 \%-75 \%$, and thus make it more comparable to com. Bran fraction removed during grain pre-processing are expected to be suitable for bakery and cercal food processing. High-starch flours yield enriched mashes and substantially higher ethanol concentrations of ethanol for distillation. The resulting stillages are high in protein and much lower in fibre and fat than com stillage. Mass and er.ergy balance and ethanol yield will be presented for bread wheat, new high-starch wheat varieties and pre-processed wheat grain. 


\title{
BIOELECTROSYNTHESIS AS AN ALTERNATIVE TO PHOTOSYNTHESIS
}

\author{
S.D. Varfolomeyev \\ M. V. Lomonosov Moscow University \\ Moscow, Russia
}

The $\mathrm{CO}_{2}$ reduction processes are discussed as a way of designing an ecologically totally closed technology. An electric current and molecular hydrogen are the two related available agents that can be discussed as ecologically pure reductants. The most important products are liquid and gaseous fuels, the products of large-scale organic synthesis, monomers, and aminoacids. For $\mathrm{CO}_{2}$ reduction, the necessary energy consumption and $\mathrm{H}_{2}$ costs were calculated. For complex organic molecules, aminoacids for instance, the energy consumption does not make up the main portion of the costs.

The biocatalytic systems of $\mathrm{CO}_{2}$ reduction based on cryoimmobilized cells are described. Conversion of $\mathrm{CO}_{2}$ into L-lysin with electrochemical decomposition of water was effected on the laboratory scale. A general unit for diverse technological processes can be a bioelectrosynthetic modulus, an electrochemical hydrogen generator coupled with a biocatalytic converter of hydrogen and oxygen. The systems for bioelectrosynthesis of motor fuels and essential aminoacids have been economically estimated and characterized. The possibilities of combining the solar energy transformation and $\mathrm{H}_{2}-\mathrm{CO}_{2}$ conversion are discussed. 
Poster iY

\title{
SYNERGISM STUDIES OF BACTERIAL AND FUNGAL CELLULASES AT LOW TOTAL CELLULASE LOADINGS
}

\author{
J.O. Baker", W.S. Adney ${ }^{a}$, R.A. Nieves ${ }^{a}$, S.R. Thomas ${ }^{a}$, \\ D.B. Wilsun ${ }^{b}$, and M.E. Himmel ${ }^{a}$ \\ ${ }^{a}$ National Renewable Energy Laboratory \\ Golden, CO 80401 \\ ${ }^{b}$ Cormell University \\ Ithaca, NY 14853
}

\begin{abstract}
A matrix of mixtures of endoglucanases and exoglucanases, drawn from both bacterial and fungal sources and used at very low total cellulase loadings (typically less than $50 \mu \mathrm{m} / \mathrm{mL}$, against $50 \mathrm{mg} / \mathrm{mL}$ microcrystalline cellulose as substrate), has been evaluated both in terms of total substrate solubilization (measured by soluble reducing-sugar production) and the degree of synergism shown by each mixture. Endoglucanases utilized included E1 from Acidothermus cellulolyticus, EG I from Trichoderma reesei, and E5 from Thermonospora fusca; enzymes used as exoglucanases included CBH I and CBH II from Trichoderma reesei, and $E_{3}$ from Thermonospora fusca. At the low total loadings used in this study, two findings were of particular interest. First, the degree of synergistic effect for the E1/CBH I and $\mathrm{E}_{5} / \mathrm{CBH}$ I mixtures peaked sharply at the low end of the range of endo/exo ratios (at less than 0.2 mole fraction endo in the constant total loading for both mixtures). Second, the degree of synergistic effect was found to vary not only with the enzyme ratios, but also to vary with the extent of substrate conversion during a given digestion. Both of these findings are discussed in terms of the selection of assay conditions for realistic evaluation of enzyme mixtures for use in actual biomass conversion processes.
\end{abstract}




\title{
MICROORGANISM INULINASE SECRETION USING CHEMICALLY MODIFIED INULINS
}

\author{
J.D. Fontana, M. Baron, and V.C. Franco \\ LQBB Biomass Chemo/Biotechnology Laboratory \\ UFPR \\ Curitiba, Parana, Brazil
}

One of the drawbacks faced on inulin enzymatic hydrolysis is its almost null solubility in water that is achieved only after moderate to strong heating. Two improvements in the enzymatic process could be expected from native inulin structure alteration through the insertion of acyl or condensed ring substituents: a) change in the solubility of the substrate/inducer, and/or b) facilitated contact of the substrate/inducer with the microorganism cell envelope thus positively affecting the inulinase induction process.

For this purpose, caproyl- or cholesteril moities from the respective chlorides were chemically transferred to native inulin and the resulting derivatives were assayed as inulinase inducers using selected Kluyveromyces yeast strains.

Inulin derivatization was monitored both by $13 \mathrm{C} \cdot \mathrm{nm}$ r and total acid hydrolysis.

Since it was found that the inulinase secretion by the yeast strains was differently affected by the presence or absence of ammonium phosphate when using native inulin: yeast extract $(10: 1)$, this supplement maintenance or omission was also adopted at the time of the induction assays using modified inulins.

Supplemented caproylated inulin proved to be a superior inulinase inducer as compared to cholesteryl-inulin, inulinase units $/ \mathrm{mL}$ in the cell free media displaying 8 and 5 times increase, respectively, as compared to the control media based in native inulin $\left(48 \mathrm{~h}\right.$ cultures at $\left.28^{\circ} \mathrm{C}, 100 \mathrm{rpm}\right)$. 


\title{
PCR PROTOCOL AND INULIN CATABOLISM-BASED DIFFERENTIATION OF INULINOLYTIC SOIL BACTERIA
}

\author{
J.D. Fontana, S. Astolfi Fo., J. Kaiss, M.C.O. Hauly, \\ V.C. Franco, R. Rogelin, and M. Baron \\ LQBB Biomass Chemo/Biotechnology Laboratory \\ UFPR \\ Curitiba, Parana, Brazil
}

Either acid or enzymatic procedures may lead to conservative hydrolysis of inulin to $\beta-2^{\prime} 1^{\prime}: \propto-2^{\prime}, 3$ difructofuranose anhydride (DFA III) thus preserving the original $\beta$-ketosidic linkage of the inulin backbone. Among the several anhydrofructobiose isomers, DFA III, initially though as an alternative (fructo)-sweetener, also provoked disturbance of free D-fructose metabolism as measured by perfusion in isolated rat liver ( $A$ ppl. Biochem. Biotechnol. 34/35) and hence the possibility of its use as a dietetic.

For the sake of inulin bioconversion potential, an already known DFA-producer, the Gram $(+)$ bacterium Arthrobacter ureafacieus (Au) was comparatively studied with two of our Dahlia tuber inulin rotters, namely "YLW" (a Gram (-) isolate). The following differential analyses were performed: a) colony and cell morphology including the variability to Gram staining; b) biochemical proves including the fermentation of several simple sugars; $c$ ) rate of inulin conversion to DFA III as determined by culture medium variations such as inulin concentration and medium supplements; and d) PCR ("Polymerase Chain Reaction") protocol from whole bacteria DNAs using short primers for genome amplification.

One outstanding property revealed by the "CRM" isolate was the production of viscous exopolysaccharides (EPS) from inulin, besides DFA III. The crude EPS was fractionated either by anion exchange on DEAE-cellulose or Cetavlon complexation at $\mathrm{pH} 7.0$ rendering an acidic rhamnogalactan separated from some residual inulin and from a neutral glycan. "CRM" cell free media also showed the presence of a reducing fructobiose. 


\title{
EFFECT OF MEDIA SUPPLEMENTATION ON ETHANOL PRODUCTION BY THE SIMULTANEOUS SACCHARIFICATION AND FERMENTATION PROCESS
}

\author{
Div. Biomasa, IER-CIEMAT \\ Avda. Complutense, 22 \\ 28040 Madrid, Spain
}

I. Ballesteros, J.M. Oliva, J.E. Carrasco, and M. Ballesteros

Ethanol toxicity represents an important biological limit to the fermentation industry. This problem is accentuated at high temperatures required in the enzymatic saccharification and simultaneous fermentation (SSF).

Kluyveromyces marxianus EMS-26 is an organism particularly well adapted to carry out a successful SSF process (1). Despite good thermotolerance, Kluyveromyces spp. appeared to have low ethanol tolerance at high temperatures, as indicated by the increased amount of residual sugar at the higher temperatures (2). A relationship between plasma membrane fluidity and ethanol tolerance has been proposed by many authors $(3,4)$. An increase in membrane fluidity caused by a higher amount of unsaturated fatty acids is supposed to increase ethanol tolerance. Some studies have shown that the incorporation of unsaturated fatty acids, sterols, or both into the cellular membrane helps to alleviate ethanol inhibition (3).

In this work, the effect of sterol and unsaturated fatty acid additions on the production of ethanol by a SSF process is evaluated.

\section{REFERENCES}

1. I. Ballesteros, M. Ballesteros, A. Cabañas, J. Carrasco, C. Martin, M.J. Negro, F. Sáez, and R. Sáez (1981). Appl. Biochem. Biotech. Vol. 28/29, 307-315.

2. D.B. Hughes, N.J. Tudroszen, and C.J. Moye (1984). Biotechnol. Lett. 6(1), 1-13.

3. S.D. Thomas, J.A. Hossack, A.H. Rose (1978). Arch. Microbiol. 117, 239-245.

4. S. Hayashida and K. Otha (1980). Agric. Biol. Chem. 44, 2561-2567. 


\title{
XYLOSE-XYLITOL: BIOHYDROGENATION BY CANDIDA PARAPSILOSIS
}

\author{
M.L. Delia-Dupuy ${ }^{a}$ and P. Strehaiano ${ }^{b}$ \\ a Laboratoire de Génie Chimique, CNRS URA 192 \\ 'Laboratoire d'Etude et d'Analyse des Procédés \\ ENSIGC 18 \\ Chemin de la Loge \\ 31078 Toulouse-Cedex, France
}

Biological production of xylitol arouses an increasing interest. This polyol represents a new opportunity for the valorization of hemicellulosics sugars. This work presents a stoichiometric approach of the xylose conversion into xylitol by Candida parapsilosis. This yeast shows good abilities to produce xylitol; the yield of conversion reaches $0,6 \mathrm{~g} / \mathrm{g}$. The study was carried out on synthetic media in order to know all the medium components. Two kinds of substrates were tested: xylose alone and a mixture of xylose (90\%) glucose (10\%). (These two sugars are the main components of hemicelluloses hydrolysates.) Nutrient supply has been limited to $1 \mathrm{~g} / \mathrm{l}$ of yeast extract so as not to take it into account for calculation while avoiding significant errors. The elemental composition of dry cell of Candida parapsilosis was determined: $\mathrm{CH}_{2,1} \mathrm{O}_{0,8} \mathrm{~N}_{0,12}$. First, the equation was calculated for a fermentation upon xylose as single substrate. " $\mathrm{CH}_{5} \mathrm{H}_{12} \mathrm{O}_{5}$ " is the chemical formula of the arabitol, byproduct of the reaction.

$$
\begin{array}{r}
\mathrm{C}_{5} \mathrm{H}_{10 \mathrm{O}}+0,547 \mathrm{O}_{2}+0,053 \mathrm{NH} \longrightarrow \\
0,446 \mathrm{CH}_{2,1} \mathrm{O}_{0,8} \mathrm{~N}_{0,12}+0,967 \mathrm{CO}_{2}+0,2 \mathrm{H}_{2} \mathrm{O}+0,674 \mathrm{C}_{5} \mathrm{H}_{12} \mathrm{O}_{5}+0,043 \text { " } \mathrm{C}_{5} \mathrm{H}_{12} \mathrm{O}_{5} \text { " }
\end{array}
$$

Then the balance was estimated when cultivation was run on a mixture of xylose and glucose.

$$
\begin{aligned}
& \mathrm{C}_{5} \mathrm{H}_{10 \mathrm{O}}+0,551 \mathrm{O}_{2}+0,044 \mathrm{NH}_{3} \longrightarrow \\
& \quad 0,365 \mathrm{CH}_{2,1} \mathrm{O}_{0,8 \mathrm{~N}_{0,12}}+0,992 \mathrm{CO}_{2}+0,18 \mathrm{H}_{2} \mathrm{O}+0,686 \mathrm{C}_{5} \mathrm{H}_{12} \mathrm{O}_{5}+0,043 \text { " } \mathrm{C}_{5} \mathrm{H}_{12} \mathrm{O}_{5} \text { " }
\end{aligned}
$$

Because xylitol production starts as glucose is depleted, the hexose does not appear in the first member of the equation. Glucose addition to the medium influences the biomass synthesis: cells use glucose for growth rather than xylose. This work specifies the stoichiometry of the bioconversion of xylose into xylitol by Candida parapsilosis, and quantifies the influence of glucose addition of xylose utilization by the yeast. 


\title{
SELECTED STRAINS AND CONTAMINANTS: A KINETIC APPROACH
}

\author{
M.L. Delia-Dupuy ${ }^{a}$, N. Ravaz ${ }^{\text {b }}$, J.P. Riba ${ }^{a}$, and P. Strehaiano ${ }^{b}$ \\ ${ }^{a}$ Laboratoire de Génie Chimique, CNRS URA 192 \\ baboratoire d'Etude et d'Analyse des Procédés \\ ENSIGC 18 \\ Chemin de la Loge \\ 31078 Toulouse-Cedex, France
}

Controlling microbial population represents a main step in the command of biological process.

The industrial use of a non-sterile media involves the presence of a natural mixed population of microorganisms. Usually, massive inoculation leads to the implantation of a selected strain. Nevertheless, this practice does not always ensure the predominance of the strain in the culture; indigenous species may compete with the seeded strain. We took interest in two topics dealing with the concomitant presence of different microorganisms:

- implantation of a strain and competition with the indigenous flora;

- contamination phenomenon.

Firstly, the influence of a killer yeast in a mixed population was studied. Such microorganism secrete a toxin lethal to sensitive strains. The killer activity may have a significant influence on population balance in a mixed culture. A couple of killer yeast/sensitive yeast was studied. Cultures were run with different starting percentages of the two strains. The killer effect was analyzed from a qualitative and kinetic point of view. The results displayed the implantation of the killer strain requires a critical concentration of the inoculum. Secondly, the contamination by Brettanomyces bruxellensis of an alcoholic fermentation plant was investigated. We were interested in the behavior of inoculation and contamination strains during co-culture. Different starting percentages and experimental conditions were tested. The behavior of the microorganisms during co-culture was analyzed. The conditions of contaminant domination were characterized: when sugar amount increases $(150 \mathrm{~g} / \mathrm{l})$ Brettanomyces bruxellensis interferes with Saccharomyces cerevisiae growth, furthermore, Saccharomyces cerevisiae very slowly develops and stays at low levels of population if added to a running culture of Brettanomyces bruxellensis. 


\title{
THE ROLE OF THE CELLULOSE-BINDING DOMAIN OF TRICHODERMA REESEI CELLOBIOHYDROLASE I IN CELLULOSE HYDROLYSIS
}

\author{
T.R. Donner ${ }^{a}$, J. Woodward ${ }^{b}$, and K. Affholter ${ }^{c}$ \\ ${ }^{a}$ Oak Ridge Science and Engineering Research Semester Student \\ from the University of Tulsa \\ Tulsa, OK 74104 \\ ${ }^{b}$ Chemical Technology Division \\ Oak Ridge National Laboratory \\ Oak Ridge, TN 37831-6194 \\ cConsultant, self-employed
}

The kinetics of the adsorption of catalytically inactivated Trichoderma reesei cellobiohydrolase I (CBH I) and resulting effects on the structure of crystalline cellulose (cotton) fibers were studied. The catalytic activity of CBH I was abolished by treatment with 1-ethyl-3-(3-dimethylaminopropyl)-carbodiimide (EDC). After modification, $\mathrm{CBH}$ I possessed no ability to hydrolyze the substrates p-nitrophenylcellobioside and barley $\beta$-glucan. Modified CBH I was still capable of adsorption to microcrystalline cellulose (Avicel). Incubation of native $\mathrm{CBH}$ I with crystalline cotton linters resulted in the smoothing of the cellulose fibers as observed by scanning electron microscopy. On the contrary, incubation of modificd $\mathrm{CBH}$ I with cotton linters had no effect on their appearance. 
Poster 24

\title{
CONVERSION OF INULIN FROM JERUSALEM ARTICHOKES TO SORBITOL AND ETHANOL BY SACCHAROMYCES CEREVISIAE
}

\author{
Z.D. Duan ${ }^{a}$, G. Turcotte ${ }^{b}$, and Z. Duvnjak ${ }^{a}$ \\ ${ }^{a}$ Department of Chemical Engineering \\ University of Ottawa \\ Ottawa, Ontario, Canada K1N 6N5 \\ bépartment de sciences de technologie des aliments \\ Université Laval \\ Cité universitaire \\ Québec, Canada G1K 7T4
}

The production and consumption of sorbitol by Saccharomyces cerevisiae ATCC 36859 have been studied in this work. The results showed that the strain produced sorbitol and ethanol in a fructose medium, but it generated only ethanol while growing in a glucose medium. When the strain was pregrown on fructose and transferred to a sorbitol medium, it consumed that polyol and produced ethanol and fructose. It did not grow on sorbitol when it was transferred from glucose medium.

This study indicated that Jerusalem artichokes can be used for the production of sorbitol and ethanol by $S$. cerevisiae ATCC 36859. Ethanol was produced from the beginning of the process, while sorbitol production started after glucose had been entirely consumed from Jerusalem artichoke juice (J.a.). The sorbitol, ethanol and biomass yields (gram of product produced per gram of sugar consumed) were $0.259,0.160$ and 0.071 at the end of the process respectively.

Adding glucose to increase its concentration to about $9 \%$ in the J.a. juice had a positive effect on the production of ethanol, while commencement of the production of sorbitol was delayed and its final concentration was less than $50 \%$ of its concentration in the medium without added glucose. 


\title{
PRODUCTION OF PHYTASE AND REDUCTION OF PHYTIC ACID CONTENT IN CANOLA MEAL BY ASPERGILLUS CARBONARIUS DURING A SOLID STATE FERMENTATION PROCESS
}

\author{
S. Al-Asheh and Z. Duvnjak \\ Department of Chemical Engineering \\ University of Ottawa \\ Ottawa, Ontario, Canada K1N 6N5
}

Phytic acid (myo-inositol hexaphosphoric acid) is the main storage form of phosphorus in many seeds and cereals. Up to $80 \%$ of total phosphorus in plants has been reported to be in the form of phytate phosphorus. Phytic acid is known for its chelating property. It binds with many multivalent cations such as $\mathrm{Ca}^{+2}, \mathrm{Fe}^{+3}, \mathrm{Zn}^{+2}$ forming insoluble complexes, and hence reduces mineral absorption. Bioavailability of proteins is also diminished owing to complex formation with phytic acid.

Canola meal is a by-product of oil production from canola seeds. It is rich in protein. Canola meal contains 3-7\% of phytic acid. Due to the nutritional implications of phytic acid, it is necessary to remove it from canola meal prior to its utilization as a feed-stuff. Phytases, among them also those of the microbial origin, can be used for the phytic acid content reduction in this commodity.

In this work, Aspergillus carbonarius was used to study the production of phytase and the reduction in phytic acid content in canola meal in a solid state fermentation process. Characteristics of the produced phytase, and the effects of parameters such as glucose, surfactant, phosphate concentrations on the processes will be shown. Mathematical models which describe the above relationships will be presented. 


\title{
UPGRADING OF CANOLA MEAL BY REDUCING ITS SINAPIC ACID ESTERS CONTENT
}

\author{
K. Lacki and Z. Duvnjak \\ Department of Chemical Engineering \\ University of Ottawa \\ Ottawa, Ontario, Canada K1N 6N5
}

Canola meal is a by-product obtained after oil extraction from canola seeds. It contains about $40 \%$ of crude proteins on a dry basis. Canola meal is used in animal feeds as a source of high quality protein with a good balance of amino acids. Its use is restricted and cannot fully replace soybean meal due to the presence of glucosinolates, phytate, fiber and phenolic compounds.

Canola contains about ten times the quantity of phenolic compounds found in soybean. Sinapine, which is an ester of sinapic acid and choline, and other esters of sinapic acid are the main phenotic compounds in canola. They contribute to the bitter flavour and dark colour of the meal and protein concentrates prepared from it. When included in the feed of laying hens, they can cause a fishy taint in brown-shelled eggs. There are more chemical methods reported for the removal of phenolic compounds from canola meal, but none of them is fully successful.

In this research, an enzyme was used for the degradation of phenolic compounds. The results showed that phenolic compounds content was reduced up to $95 \%$ of their initial amount. The effect of temperature, $\mathrm{pH}$, enzyme concentration, ratio meal/liquid phase on the degradation of phenolic compounds was investigated. It was noticed that the enzyme used in this research was quite thermostable in the presence of canola meal. 


\title{
SCREENING OF ACETOGENIN-LIKE COMPOUNDS IN BRAZILIAN FLORA: ANNONA AND ROLLINLA SPP.
}

\author{
J.D. Fontana, M. Baron, F.C. Deschamps, M.F. Guimaraes, \\ F. Zanette, A.C. Cervi, and E.R.A. Almeida \\ LQBB Biomass Chemo/Biotechnology Laboratory \\ UFPR \\ Curitiba, Parana, Brazil
}

\begin{abstract}
A recent report from J. MacLaughlin (Purdue University) on acetogenins from Asimina triloba, an Annonaceae common to USA eastern states, renewed the interest in natural substances displaying strong bioactive action such as tumourogenesis blockade in mouse ovary.

Our original interest in Annona sp. ("fruta-do-conde") seed xyloglucan was then extended to small lipophylic components from the same issue as well as from other anotomical parts such as leaves, bark, and roots. Another related genus from Brazilian flora, Rollina sp., was also submitted to the same organosolv isolation procedure. Semi-preparative TLC run of the crude extracts in silica-gel ensured the minimal resolution for some components further used for the preliminary biological tests exploring brine shrimp lethality and Agrobacterium tumefaciens development inhibition on potato disks.
\end{abstract}

Comparative results obtained from the different botanical sources and their parts will be presented looking for more important applications like the antineoplastic performance in animal or human cell lines. 


\title{
$\alpha-X Y L O-\beta-G L U C A N$ MONOMERIZATION AND PLANT PROTOPLAST RELEASE USING THE HYDROLASE COMPLEX FROM THE GASTRIC JUICE OF THE LAND SNAIL MEGALOBULIMUS
}

\author{
J.D. Fontana, M. Gebara, and I.N. Lyra \\ LQBB Biomass Chemo/Biotechnology Laboratory \\ Department of Biochemistry - UFPR \\ Curitiba, Parana, Brazil
}

Following the discovery that hepta- and nonassaccharides derived from native fucosylated xyloglucans can modulate the cellulogenic/cellulolytic exchange occurring in the plant cell wall biosynthesis/rearrangement, the interest in this kind of native polymers, intimately linked to cell wall cellulose but also playing the role of seed reserve for other plants, have experienced significant increase. There are a few reports in the literature concerning the specific enzymes requiring xyloglucan processing, since, differently from the usual grass and legume hemicelluloses, i.e., $\beta$-1, 4-linked (hetero)xylans, D-xylose appears as single substituent and $\beta$-1, 6 -linked to a microcellulose backbone in xyloglucans. Other structurally differential feature among xyloglucans from several botanical sources is the occurrence of minor peripherical substituents such as D-galactose, L-arabinose, and L-fucose.

We found that the gastric juice from Megalobulimus paranaguensis is able performing "in vitro" complete hydrolysis of xyloglucans as well as the release of protoplasts from leaflets and leaves of several plants of economical interest (Araucaria, the Parana pine; Avena, Gossypium, Stevia, Manihot). In some instances, the protoplast-generating process is further improved by previous reinforcement of snail enzymes with fungal cellulases. The contribution of $\alpha$-xylo- $\beta$-glucanases for such an issue disorganization and selective cell denuding, if one really does exist, is being investigated. 


\title{
DEHYDROGENASE ACTIVITY MEASUREMENT IN AEROBIC WASTE TREATMENT SYSTEMS
}

\author{
A.E. Ghaly \\ Technical University of Nova Scotia \\ Halifax, Nova Scotia, Canada B3J 2 X4
}

The effect of solid concentration on the growth of heterogenous microbial population in swine manure was studied under batch and continuous aerobic conditions. Dehydrogenase activity was used as a measure of active biomass in the manure in preference of other biochemical parameters because of the simple but accurate nature of the test. The growth curve of the heterogenous microbial population in swine manure was essentially similar to that of a pure culture grown batchwise except that the exponential growth phase followed a diauxic growth pattern. High concentration of manure had an inhibitory effect on the microbial growth under both batch and continuous conditions. 


\title{
NEW METHODS OF IMPROVING HYDROGEN YIELDS BY PHOTOSYNTHETIC WATER SPLITIING ${ }^{1}$
}

\author{
E. Greenbaum ${ }^{2}$, S.L. Blankinship ${ }^{a}$, and R.M. Cinco ${ }^{b, 2}$

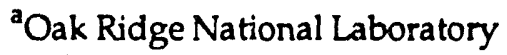 \\ Oak Ridge, TN 37831-6194 \\ buniversity of California-Berkeley \\ Berkeley, CA $94530-3920$
}

Molecular hydrogen is a valuable chemical fuel and feedstock that can be produced by the simultaneous photoevolution of hydrogen and oxygen via photosynthetic water splitting. In the experiments reported in this presentation, the carbon dioxide concentration of Chlamydomonas reinhardtii was regulated as a means of partitioning photosynthetic reductant between the Calvin cycle and the hydrogenase/hydrogen-evolving pathway. Real-time kinetic competition between these two pathways was observed. The experimental results are summarized as follows. In the range 58 to $0 \mathrm{ppm} \mathrm{CO}$, the hydrogen yields (for $1.5 \mathrm{~h}, 130 \mathrm{~W} \cdot \mathrm{m}^{-2}$ photosynthetically active radiation irradiance) increased from $1,790 \mathrm{nmol}$ at $58 \mathrm{ppm} \mathrm{CO}$ to $11,360 \mathrm{nmol}$ at $0.8 \mathrm{ppm} \mathrm{CO}$ and then decreased to $3,978 \mathrm{nmol}$ at $0 \mathrm{ppm} \mathrm{CO}$ (all yields and rates were normalized to $1-\mathrm{mg}$ chlorophyll). Also, as judged from the first decay half-life, hydrogen production rates were better maintained during the high-yield periods. For the same range, oxygen yields decliner from 16,330 to 2,030 nmol at $0 \mathrm{ppm}$ $\mathrm{CO}_{2}$ (12\% of the $58 \mathrm{ppm}$ value). A CO2 concentration of $0.8 \mathrm{ppm}$ was the optimum level for maximized $\mathrm{H}_{2}$ yield, with $11,360 \mathrm{nmol}$. The $\mathrm{O}_{2}$ was $28 \%$ at $58 \mathrm{ppm} \mathrm{CO} 2-4,540$ vs $16,330 \mathrm{nmol}$. The key result of this study was that control of atmospheric $\mathrm{CO}_{2}$ concentration can be used to control the branching ratio between the hydrogen evolution/hydrogenase pathway and $\mathrm{CO}_{2}$ assimilating Calvin-Benson cycle pathway and that there is a low (but nonobvious) optimum value at which this occurred. The data presented in this work graphically illustrate the way in which the transition ocurs. For the $s$ wild-type algae, the dual role of $\mathrm{CO}_{2}$ in photosynthesis prevented exclusive suppression of the Calvin cycle without impairing electron transport (as indicated by $\mathrm{O}_{2}$ production). Stoichiometric ratios of hydrogen to oxygen are reported as functions of $\mathrm{CO}_{2}$ conentration.

\footnotetext{
${ }^{1}$ Research supported by the Office of Basic Energy Sciences and Pittsburgh Energy Technology Center, U.S. Department of Energy.

${ }^{2}$ Participant in the Oak Ridge Science and Engineering Research Semester. Present address: Department of Chemist.y, University of California at Berkeley, Berkeley, CA 94720.
} 
Poster 31

\title{
BIOCONVERSION OF CARBOHYDRATES IN ORANGE PEEL TO ETHANOL
}

\author{
K. Grohmann and E.A. Bald win
}

\section{U.S. Citrus and Subtropical Products Research Laboratory Winter Haven, FL 33883-1909}

\begin{abstract}
Large amounts of peel, cores, and segment membranes accumulate during processing of citrus fruit to juice and similar products. The overwhelming majority of citrus fruit processed to juice products is supplied by several varieties of oranges and a minor portion by grapefruit. The citrus processing residues are currently pressed, dried, and sold at a marginal profit as cattle feed. High content of carbohydrates and soluble sugars in particular make citrus processing residues an attractive feedstock for biological production of fuels ind chemicals. This presentation will discuss experimental results of the hydrolysis of orange peel with commercial cellulase and pectinase enzymes, and fermentation of the hydrolyzates to ethanol. High yields of monomeric sugars were obtained by the hydrolysis of orange peel with pectinase or pectinase supplemented with cellulase enzyme. Relatively rapid rates of enzymatic hydrolysis of all polysaccharides in orange peel were also observed. The major sugars released by enzymatic hydrolysis and extraction of orange peel were galacturonic acid, glucose, fructose, arabinose, and galactose. Minor amounts of xylose and rhamnose were also released. Preliminary results of batch fermentations using Saccharomyces cerevisiae indicate presence of yeast inhibitors in whole peel hydrolyzates. Identification of inhibitors and development of methods for their removal are in progress.
\end{abstract}




\title{
STUDIES ON DIRECTIVE SCREENING OF HIGH PROTEIN CONTENT STRAINS OF SCP
}

\author{
C. Hongzhang \\ Shandong Institute of Chemistry \\ Jinan 250014, China
}

The yeast Trichosporon Cutaneum 851 was selected as a SCP production strain from 25 strains of fungi by its ability of using the oligomers of xylose in steam exploded hemicellulose autohydrolysate liquor directly and growing rapidly in the medium. But the protein content of the strain was only $35.0 \%$. After combination mutation by $\mathrm{UV}$ and $\mathrm{HNO}_{2}$, enrichment, dye, was obtained with an increased protein content of $47.0 \%$ and a methionine content of $27.7 \mathrm{mg} / \mathrm{g}$ biomass. For SCP production, only small amounts of nitrogen source was needed to be supplemented to the hemicellulose autohydrolysate liquor. The optimal fermentation time of the strain is 16 hours. 


\title{
PECTINOLYTIC ENZYMES IN NEW TRUE CELLULOLYTIC YEAST-LIKE FUNGUS, AUREOBASIDIUM SP. CH-M-1018
}

\author{
R. Pérez, M.E. Flores, and C. Huitrón \\ Department of Biotechnology for Biomedical Research \\ National University of Mexico, \\ 04510 México
}

An increase in the application of pectinases in the food industry has been observed. Their use is very important for the clarification of fruit juices and the extraction of juices and colorful substances, which are needed for the preparation of fruit nectars and vegetable purees. The presence of endo-polygalacturonase-(endo-PG) is essential for these applications.

Work with the yeast-like fungus Aureobasidium sp. CH-M-1018 is being performed at our laboratory. It has turned out to be a true cellulolytic microorganism. It produces extracellular cellulases and xylanases when it is grown on microcrystalline cellulose or sugar-cane bagasse pith. Since agroindustrial by-products contain pectin, the types of pectinolytic activities produced by the fungus were studied when it was grown on: sugar-cane bagasse pith, lemon peel, pectin - and microcrystalline cellulose. Catabolite-repression exerted by low molecular weight carbon sources, was also studied.

The results obtained show the biosynthesis of extracellular endo-PG, exo-PG, and pectin-lyase activities by Aureobasidium sp. CH-M-1018 in the presence of sugar-cane bagasse pith, pectin and lemon peel. A negative effect upon the addition of glucose and glycerol was also found. Galacturonic acid showed both effects stimulation and repression, depending on the time when it was added. It is noteworthy that higher endopectinases production was found when the fungus was grown on sugar cane bagasse pith under the optimal conditions for cellulases production. This results indicate that a filtrate from Aureobasidium containing a most complete enzyme mixture could be more efficient for the bioconversion of agroindustrial by-products. 


\section{MICROBIAL CONVERSION OF HIGH RANK COALS TO METHANE}

E.R. Johnson, K.T. Klasson, R. Basu, J.C. Volkwein, E.C. Clausen, and J.L. Gaddy

University of Arkansas

Department of Chemical Engineering

Fayetteville, AR 72701

It has been demonstrated recently that certain bacteria and fungi are capable of directly or indirectly converting low rank coals into liquid and gaseous fuels. There has been at least preliminary evidence that indicates that microbial consortia are responsible for generating methane from bituminous coal. Building upon this work, a study was undertaken to test selected anaerobic microbial consortia for their ability to degrade and produce methane from bituminous coals. This paper reports on the results of the study. At least three consortia have shown the ability to produce methane from hard coals without the presence of yeast extract in the culture medium. 


\title{
DEVELOPMENT OF A BUFFERED MEDIUM FOR CELLULASE FERMENTATION STUDIES WITH T. REESEI RUT-C3O
}

\author{
K.L. Kadam and W.J. Keutzer
}

\author{
Alternative Fuels Division \\ National Renewable Energy Laboratory \\ Golden, CO 80401
}

Economic production of cellulases is imperative for the success of the biomass-to-ethanol process. $T$. reesei Rut-C30 is a well-studied cellulase producer which can be employed in this process. The enzyme production costs can be lowered by process improvements such as inexpensive inducers, more efficient mutants, etc. The efficacy of such advancements can be tested in shake flasks and later confirmed in stirred fermenters. However, the $\mathrm{pH}$ during $T$. reesei fermentation needs to be controlled at around 4.8 for optimal performance; this is only possible in shake flasks via manual control, which is tedious and inefficient. Hence, development of a buffered medium was attempted using several physiologically compatible buffers. Acetate, succinate, citrate, phthalate, and phosphate buffers at different concentrations and in various combinations were employed. The criterion used for judging the buffers was their ability to maintain the $\mathrm{pH}$ at the desired level without affecting enzyme yield or productivity. The results of this study and their application in shake flask experiments will be presented. 


\title{
PHANEROCHAETE MUTANTS WITH ENHANCED LIGNINOLYTIC ACTIVITY
}

\author{
S.N. Kakar \\ Argonne National Laboratory \\ Argonne, IL 60439
}

Over the past several years Phanerochaete chrysosporium, a white-rot basidiomycete fungus, has received considerable attention because of the significant role of its ligninolytic system in the delignification of plant materials and in the mineralization of a wide variety of aromatic environmental pollutants. The fungus and its ligninolytic system have excellent potential in the chemical, animal feed, and paper and pulp industries and also in pollution control. The enzymes of the ligninolytic system of the fungus are produced only as secondary metabolites triggered by nitrogen or carbon limitation and thus are produced inefficiently and in small quantities. This mode of production severely limits the usefulness of the fungus in bioremedial or industrial applications. Classical genetics has always provided a key approach for strain improvement through the isolation of mutants that can overproduce and secrete the important enzymes. We have isolated a variety of mutants through UV and gamma ray mutagenesis. Some of these mutants appear to be deregulated and produce the key enzymes of the ligninolytic system (peroxidases) under high-nitrogen growth conditions. One of the mutants (76UV) produced 272 units of lignin peroxidase enzyme activity per liter under highnitrogen growth conditions in six days. The parent strain does not produce lignin peroxidase at all under these conditions. In contrast, the mutant and the parent strain produced the enzyme at only 22 and 23 units/liter under low-nitrogen growth conditions during the same period. In some experiments the mutant produced enzyme activity at 40 units/liter after three days under high nitrogen and retained enzyme activity at 219 units/liter after 17 days. In the wild-type strain, the enzyme activity declines sharply after 10 days under low-nitrogen conditions. The isolation and characterization of the mutants and their potential use in bioremediation and other industrial applications will be discussed in detail. 


\title{
SYNERGISM IN CLEAVING AVICEL BY CLOSTRIDIUM THERMOCELLUM CELLULASES PRODUCED IN ESCHERICHLA COLI
}

\author{
S.V. Kalyuzhnyi ${ }^{a}$, T.P. Mosolova ${ }^{b}$, S.D. Varfolomeyev ${ }^{b}$, \\ and G.A. Velikodvorskaya ${ }^{c}$

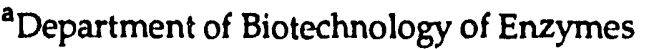 \\ Chemistry Faculty \\ Autonomous University of Coahuila, Mexico \\ bepartment of Chemical Enzymology \\ Chemistry Faculty \\ M.V. Lomonosov Moscow University, Russia \\ 'Institute of Molecular Genetics \\ Kurchatov sq. 46, 123182 Moscow, Russia
}

Endoglucanase 5 (EG5) has been isolated (98-fold purification, 27\% final yield) from the strain of $E$. coli TG1 harboring recombinant plasmid pCU108, which contains ce15 gene of C. thermocellum. The enzyme has a molecular mass of $35 \mathrm{kDa}$ and includes 3 multiple forms with pl 4.4-4.8. EG5 cleaves CMC, amorphous cellulose, xylan, lichenan with optimum temperature of $80^{\circ} \mathrm{C}$ and $\mathrm{pH} 6.0$ and Avicell with optimum temperature of $60^{\circ} \mathrm{C}$ and $\mathrm{pH} 6.0$. Cellobiose in concentrations up to $200 \mu \mathrm{m} / \mathrm{mL}$ does not inhibit the hydrolysis of CMC by EG5, but $10-30 \mu \mathrm{g} / \mathrm{mL}$ of glucose insignificantly decreases the activity of this enzyme. Stimulating role of calcium chloride has been demonstrated for Avicel hydrolysis by EG5.

EG5 together with $C$. thermocellum endoglucanase 7 (EG7) and celiobiohydrolase 3 (CBH3) also produced in E. coli acts synergistically in cleaving Avicel. Variation of some parameters affecting to Avicel hydrolysis (relative amounts of substrate and each of enzymes, time of incubation) were studied. Maximum synergism extent (3.2) was observed through $20 \mathrm{~h}$ after beginning of a reaction when $7.5 \mu \mathrm{g}$ of EG5, $50 \mu \mathrm{g}$ of EG7 and $120 \mu \mathrm{g}$ of $\mathrm{CBH} 3$ hydrolysed $125 \mathrm{mg}$ of Avicel at $60^{\circ} \mathrm{C}, \mathrm{pH} 5.8$. Addition of $10 \mathrm{mM}$ calcium chloride resulted in 1.3-fold increase of synergism extent. In the presence of bovine serum albumin synergism wasn't observed. Synergism extent depended on the order of addition of enzymes to Avicel. The yield of reducing sugars under simultaneous action of enzymes was in two times higher than when they acted consecutively. 


\title{
THE PH-DEPENDENT ENERGETIC UNCOUPLING OF ZYMOMONAS BY ACETIC ACID
}

\author{
H.G. Lawford and J.D. Rousseau \\ Department of Biochemistry \\ University of Toronto \\ Toronto, Ontario, Canada M5S 1A8
}

\begin{abstract}
Although Saccharomyces yeast currently enjoys a monopoly in the fuel alcohol industry, it is not the only ethanol producing microorganism. The bacterium Zymomonas mobilis is generally recognized as being superior to Saccharomyces yeast with respect to both glucose conversion efficiency and productivity. Although Zymomonas is not currently being used industrially, both laboratory and pilot-scale operations have shown that it is capable of generating near theoretical maximum yields from several different feedstocks, including sugar cane, molasses, saccharified starch from corn, wheat, cassava and sago, as well as enzymatic or acid hydrolysates of cellulose.
\end{abstract}

Acetic acid (HAC) is normally regarded as an effective antimicrobial agent is used as such in both the food and beverage industries. Our interest in the effect of HAc on Zymomonas grew out of studies on the effect of lactic culture contamination (Bringer et al., 1984; Lawford \& Rousseau, 1992) as well as our appreciation of the problems caused by its presence in hemicellulose hydrolysates. At this meeting last year, we reported some initial observations in connection with our systematic physiological analysis of the effect of HAc on Zymomonas at $\mathrm{pH}$ 5. The undissociated acid is able to permeate the plasma membrane. The transmembrane $\mathrm{pH}$ drives the accumulation of HAc which results in the acidification of the cytoplasm. The consequential increase in maintenance metabolism that is required for homeostasis of cytoplasmic $\mathrm{pH}$, represents a division of energy that would otherwise be available for growth. Accordingly, it was previously concluded that HAc acts in a dose-dependent manner to promote 'energetic uncoupling' of Zymomonas. The present study examines the $\mathrm{pH}$-dependent nature of this phenomenon. Since too much HAc causes cell death, the objective was to define the quantita ive relationship between effective dose and $\mathrm{pH}$. Whereas at $\mathrm{pH} 5.0,10 \mathrm{~g} / \mathrm{L}$ is completely inhibitory, at lesser concentrations there can be as much as a $100 \%$ increase in specific productivity (Lawford \& Rousseau, Appl. Biochem. Biotechnol., 1993). It is proposed that this 'uncoupling' effect of HAc could be commercially exploited in 'closed' continuous ethanol fermentations (e.g. cell-recycle system or immobilized cell reactor) to greatly enhance productivity. This would involve similar strategies to those used in designing the patented ZymoGen Process. 
Poster 39

\title{
EFFECT OF OXYGEN ON ETHANOL PRODUCTION BY A RECOMBINANT ETHANOLOGENIC E. COLI B (PLOI297)
}

\author{
H.G. Lawford and J.D. Rousseau \\ Department of Biochemistry \\ University of Toronto \\ Toronto, Ontario, Canada M5S 1 A8
}

At the past three meetings, we have reported on various aspects of our continuing investigation of the physiological characteristics of a genetically engineered Escherichia coli B (carrying the PET operon with genes from Zymomonas on plasmid pLOI297) (Ingram et al., US Pat. 5,000,000) with a view to assessing its suitability for the production of fuel ethanol from lignocellulosic biomass.

It has been claimed that "the presence of the $Z$. mobilis ethanol pathway enzymes in $E$. coli under oxidative conditions diverts over $90 \%$ of the carbon and prevents the additional energy generation which normally occurs during oxidative growth" (Ingram, 1990). Consequently "recombinant E. coli strains expressing the PET operon are debilitated in comparison to wild-type organisms with respect to competitive survival in the natural environment..." (Ingram et al., 1990).

Since the energy yield of oxidative metabolism (aerobic conditions) is many times greater than from anaerobic fermentation, it would be expected that the growth yield under aerobic conditions would be higher, but only if the recombinant cells were able to derive more ATP from the same amount of sugar when oxygen was added to the medium at a rate that surpassed the oxygen demand of the culture. Both the cloned Zymomonas alcohol dehydrogenase and the native $E$. coli respiratory chain NADH oxidase enzymes exhibit equally high affinities for NADH, but the respiratory chain could represent the preferred oxidative route for NADH when oxygen is supplied at a rate exceeding the oxygen demand such that the DOT DOT ${ }_{\text {crit. }}$. We have observed that, under aerobic conditions (OTR $=100 \mathrm{mmol} \mathrm{O} / \mathrm{L} / \mathrm{hr}$ ), (i) the growth rate is almost 7 times faster, (ii) the molar growth yield (xylose) is about 4.5 times higher, and (iii) the ethanol yield is only $0.29 \mathrm{~g} / \mathrm{g}$ (57\% conversion efficiency), which is similar to that achieved by the parent culture (ATCC 11303) under anaerobic conditions. The conclusions made about aerobic metabolism and the fate of this type of genetic construct "in the natural environment", should be reassessed in the light of this study. 


\title{
RELATIVE RATES OF ETHANOL PRODUCTION \\ BY AN ETHANOLOGENIC E. COLI B (PLOI297) USING MDXTURES OF GLUCOSE, MANNOSE AND XYLOSE
}

\author{
H.G. Lawford and J.D. Rousseau \\ Department of Biochemistry \\ University of Toronto \\ Toronto, Ontario, Canada M5S 1A8
}

Efficient utilization of hemicellulose from lignocellulosic feedstocks offers an opportunity to increase the yield and to reduce the cost of producing fuel ethanol. The composition of hemicellulose varies from being predominantly mannan in softwoods to predominantly xylan in hardwoods. Recombinant Escherichia coli B (ATCC 11303), carrying the plasmid pLOI297 with pyruvate decarboxylase and alcohol dehydrogenase II genes from Zymomonas mobilis, converts xylose to ethanol with a product yield that approaches theoretical maximum (US. Pat. 5,000,000)

At the past three meetings, we have reported on various aspects of our continuing physiological fermentation performance assessment of this patented, genetically engineered, ethanologen. Our investigations have included both laboratory media and industrial feedstocks, including various wood prehydrolysates, com cob hydrolysate and spent sulphite liquors from both hardwood and sof twood. Because of the high xylan content, hardwoods are the preferred feedstock in systems capable of efficient xylose utilization. Pentose conversion is anticipated to have less economic impact when scitwood is utilized as fermentation feedstock. The fermentation performance characteristics of recombinant $E$. coli $\mathrm{B}$ (pLOI297) using sugar mixtures has not been examined extensively, although xylose 'sparing' by hexose sugars has been reported (Beall et al., 1992).

In this study, we have examined the relative rates of ethanol production using synthetic hemicellulose hydrolysates consisting of sugar mixtures of glucose, mannose and xylose in an attempt to quantitate the interactive relationship between hexose and pentose metabolism. More specifically, we were interested in the effect of glucose and/or mannose on xylose metabolism by the genetic construct in terms of the ethanol yield potential from hemicellulose hydrolysates of different lignocellulosic feedstocks. 
Poster 41

\title{
IN SITU PHOTOPRECIPITATION OF METALLOCATALYSTS FOR MOLECULAR HYDROGEN PRODUCTION WITH PHOTOSYNTHETIC WATER SPLITTING IN THYLAKOIDS ${ }^{1}$
}

\author{
J.W. Lee, G.V. Tevault, S.L. Blankinship, \\ R.T. Collins ${ }^{2}$, and E. Greenbaum \\ Oak Ridge National Laboratory \\ Oak Ridge, TN 37831-6194
}

Simultaneous photoproduction of molecular hydrogen and oxygen by photosynthetic water splitting has been demonstrated in platinized thylakoids. $\mathrm{H}_{2}$ is synthesized through reduction of protons, catalyzed by platinum colloid particles at the reducing side of photosystem I (PSI) on the thylakoid membrane. Subsequently, a second technique was developed to specifically platinize the reducing end of PSI. This technique uses hexachloroplatinate $\left[\mathrm{PtCl}_{6}\right]^{-2}$ as a Hill oxidant which accepts electrons directly from PSI. Unlike the common Hill reagent ferricyanide, $\left[\mathrm{PtCl}_{6}\right]^{-2}$ is able to accept four electrons consecutively from PSI, presumably by converting $\left[\mathrm{PtCl}_{6}\right]^{-2}$ anions to zero valent metallic platinum at the reducing end of PSI. It was experimentally confirmed that this photoplatinization can be achieved with moderate actinic illumination $\left(2 \times 10^{15}\right.$ quanta $. \mathrm{s}^{-1} . \mathrm{cm}^{-2}$ ) in about $15 \mathrm{~min}$ for thylakoids of $3 \mathrm{mg}$ chlorophylls in $5 \mathrm{ml}$ Walker's assay medium (pH 7.0) containing $2 \mathrm{mM}\left[\mathrm{PtCl}_{6}\right]^{-2}$. The photoplatinization was marked as a phase of fast $\mathrm{O}_{2}$ evolution as a consequence of electron consumption by $\left[\mathrm{PtCl}_{6}\right]^{-2}$ in the Hill reaction. The photoplatinization was then followed by an onset of $\mathrm{H}_{2}$ production, resulting in a simultaneous evolution of both $\mathrm{O}_{2}$ from water splitting by PSIl and $\mathrm{H}_{2}$ from the metallic platinum-catalyzed reduction of protons at PSI by linearly transported electrons from water splitting. This simultaneous $\mathrm{O}_{2}$ and $\mathrm{H}_{2}$ production can be sustained for over 20 hours with continuous illumination at room temperature.

In addition, hexachloroosmiate $\left[\mathrm{OsCl}_{6}\right]^{-2}$, hexachloroiridates $\left[\mathrm{IrCl}_{6}\right]^{-2}$, and $\left[\mathrm{IrCl}_{6}\right]^{-3}$ were also tested. Our results indicated that $\left[\mathrm{OSCl}_{6}\right]^{-2}$ can also be photoprecipitated as a metallocatalyst at PSI, but with a rate about $50 \%$ slower than that of $\left[\mathrm{PtCl}_{6}\right]^{-2}$. However, once photoprecipitated, its catalytic action for $\mathrm{H}_{2}$ production was similar to that of metallic platinum. A simultaneous photoevolution of $\mathrm{O}_{2}$ and $\mathrm{H}_{2}$ was also achieved in $[\mathrm{OsCl}]^{-2}$ photo-treated thylakoids. Surprisingly, neither $\left[\mathrm{IrCl}_{6}\right]^{-2}$ nor $[\mathrm{IrCl}]^{-3}$ treated thylakoids was able to produce any $\mathrm{H}_{2}$. Our analysis indicates that $\left[\mathrm{IrCl}_{6}\right]^{-2}$ was able to accept only one electron by transforming into $\left[\mathrm{IrCl}_{6}\right]^{-3}$ which was completely unable to acquire electrons from PSI. It is interesting to note that $\left[\mathrm{IrCl}_{6}\right]^{-2}$, $\left[\mathrm{PtCl}_{6}\right]^{-2}$ and $\left[\mathrm{OsCl}_{6}\right]^{-2}$ are structurally and thermodynamically similar. Thus, their difference in the ability to accept electrons from PSI is probably due to differences in their molecular orbital interactions with the reducing side of PSI. The inability of $\left[\mathrm{IrCl}_{6}\right]^{-2}$ reduction to metallic iridium is apparently due to a high energy level barrier of $\left[\mathrm{IrCl}_{6}\right]^{-3}$ reduction.

\footnotetext{
${ }^{1}$ Research supported by the Office of Basic Energy Sciences and Pittsburgh Energy Technology Center, U.S. Department of Energy.

${ }^{2}$ Oak F.idge National Laboratory Special Honors Study Program participant, West High School, Knoxville, TN.
} 


\title{
PURIFICATION AND CHARACTERIZATION OF AN ACETYLESTERASE FROM ASPERGILLUS NIGER
}

\author{
J.C. Linden", M. Samara ${ }^{a}$, E. Thomas ${ }^{a}$, M. Joy ${ }^{a}$, \\ S. Decker ${ }^{a}$, M. Pecs ${ }^{b}$, W. Adney, and M. Himmel ${ }^{c}$ \\ aDepartment of Microbiology \\ Colorado State University \\ Fort Collins, CO 80523 \\ buniversity of Technical Sciences \\ Budapest, Hungary \\ ${ }^{c}$ Alternative Fuels Division \\ National Renewable Energy Laboratory \\ Golden, CO 80401
}

Optimized acetylesterase enzyme production conditions using Aspergillus niger ATCC 10864 in $14 \mathrm{~L}$ fermentation jars were determined to be $33^{\circ} \mathrm{C}, 1.5 \mathrm{vvm}$ aeration and $300 \mathrm{rpm}$ agitation without pH control. The acetylesterase was purified by precipitation in 60 to 80 percent saturation in ammonium sulfate. The pellet was applied directly to a Pharmacia high load Phenyl Sepharose column for hydrophobic interaction chromatography and purified to homogeneity in two steps.

Stability and kinetic characteristics of the acetylesterase were determined over a pH range of 4.0 to 7.5 and from $4^{\circ}$ to $45^{\circ} \mathrm{C}$. At temperatures greater than $25^{\circ} \mathrm{C}$, stability was superior at $\mathrm{pH}$ values less than 5.0 than at higher $\mathrm{pH}$ values. The temperature activity optimum was $35^{\circ} \mathrm{C}$ and the $\mathrm{pH}$ optimum was 7.0 . The $\mathrm{V}_{\max }$ was determined to be 46,700 units $/ \mathrm{mg}$ protein and the $K_{\mathrm{m}}$ was $0.023 \mathrm{M} \mathrm{p}$-nitrophenylacetic acid at pH 6.5 in $0.2 \mathrm{M}$ phosphate buffer at $35^{\circ} \mathrm{C}$. The molecular weight of the enzyme was 35,000 daltons by size exclusion chromatography. The N-terminal amino acid sequence, the glycosylation composition, isoelectric point and SDS molecular weight were also determined. 
Poster 43

\title{
SYNTHESIS OF CYCLODEXTRIN GI.YCOSYL TRANSFERASE BY BACILLUS CEREUS FOR THE PRODUCTION OF CYCLODEXTRINS
}

\author{
R. Jamuna and S. V. Ramakrishna \\ Council of Scientific and Industrial Research \\ Kerala, India
}

Cyclodextrin glycosyl transferase enzyme (CGTase) [E.C.2.4.1.19] is a unique extracellular transglycosidase catalysing the reversible intermolecular and intramolecular -1, 4-transglycosylation of starch, performing cyclizing, coupling and disproportionation of glucose residues, resulting in the formation of cyclic molecules called cyclodextrins. We have isolated an indigenous strain characterized Bacillus cereus RJ 30 (NCIMB 12123) capable of synthesizing CGTase. The growth dynamics and the synthesis of CGTase during the growth and differentiation of the organism has been studied extensively. Optimization of the various fermentation parameters was carried out for the maximization of the enzyme synthesis. It has been found that the organism has a specific growth rate of 0.69 with a generation time of $1 \mathrm{hr}$. The CGTase enzyme was produced from the early exponential growth and peaked up during the mid sporulating stage $(\sim 16 \mathrm{hrs})$, thereafter maintained at the same level of 50 units $/ \mathrm{ml}$. Bacillus cereus has a high specific growth rate as compared to Bacillus circulans ATCC 21783 which has a specific growth rate of 0.25 . This organism did not utilize startch unlike B.circulans and the influence of the carbohydrate substrates has indicated that the enzyme synthesis is promoted by $x y$ lose [65 units $/ \mathrm{ml}$ ] and most significantly by wheat bran extract supplementation in glucose medium [106 units $/ \mathrm{ml}]$.

We have investigated the stability of this organism for producing CGTase continuously. This has been demonstrated by the chemostat culturing over a period of 400 hours. The maximum productivity attained was $5.4 \mathrm{KU} / 1 / \mathrm{h}$ which is 3 fold higher than that was obtained in the case of a batch fermentation $[1.75 \mathrm{KU} / 1 / \mathrm{h}]$.

We have also extended our investigations on the synthesis of CGTase using immobilized cells of Bacillus cereus. We have demonstrated the continuous synthesis of CGTase in a fluidized bed reactor at a relatively higher dilution rate $0.88 \mathrm{~h}-1$ with a productivity of $3.0 \mathrm{KU} / 1 / \mathrm{h}$ for 360 hours.

Thus the present communication deals with the physiology of growth and sporulation of the organism concommitant with the CGTase synthesis and the feasibility of the continuous synthesis by chemostat culturing using free cells and in a fluidized bed reactor using immobilized cells. 


\title{
MATHEMATICAL MODEL OF SUBSTANCE ACTIVE TRANSPORT INTO MICROBLAL CELLS AT CONCENTRATION GRADIENT
}

\author{
Y.R. Malashenko, I.G. Sokolov, and F.V. Muchnik \\ Ukrainian Academy of Sciences \\ Zabolotny Institute of Microbiology and Virology \\ 252143, Kiev, The Ukraine
}

It was shown experimentally that methane oxidation is seized after the dissipation of the electrochemical gradient across the cytoplasmic membrane of methane-oxidizing bacteria.

Such as observation allows the supposition that in methanotrophs there is a peculiar mechanism of the active transport of methane, so far unknown, occurring at the substance concentration gradient. Thermodynamically the process must go with the energy consumption. Supposedly such processes can occur during the uptake of metabolized substrate by microbial cells or during the excretion of metabolites out of the cells in case when the enzyme affinity for the substrate is high or when the passive diffusion rate is the limiting factor.

The mathematical model of the substance active transport process across the cytoplasmic membrane of a coccoid bacterial cell at the concentration gradient with metabolic energy consumption is built. The model is the initial-boundary-value task for equations in partial derivatives of the second order of parabolic type.

The model can be made use of in biotechnological research for the prediction of the microbial metabolism efficiency at the production site, for instance, in the optimization of the methanogenesis or pollutants bioconversion rate in the environment. 


\title{
PHOTOBIOLOGICAL CONVERSION OF SYNTHESIS GAS INTO BIODEGRADABLE PLASTICS
}

\author{
P.-C. Maíéş and P.F. Weaver \\ Photoconversion Branch \\ National Renewable Energy Laboratory \\ Golden, CO 80401
}

\begin{abstract}
A novel process is described to efficiently photoconvert low-grade organic materials such as waste biomass into natural biological plastics. When heterogeneous forms of dry biomass are thermally gasified, relatively homogeneous synthesis gas mixtures comprised primarily of carbon monoxide and hydrogen are produced. Unique strains of photosynthetic bacteria have been isolated that nearly quantitatively photoassimilate the carbon monoxide and hydrogen components of synthesis gas into new cell mass. Under unbalanced culture conditions when cellular growth is limited by shortages of nitrogen, calcium, magnesium, iron, or essential vitamins, or by an increase of medium $\mathrm{pH}$, a large fraction of the new cell mass is found as granules of poly-3-hydroxybutyrate (PHIB), a high molecular weight thermoplastic which could be solvent extracted. PHB has physical properties similar to polysiyrene or polypropylene. When a green alga was co-cultured with the photosynthetic bacteria in light/dark (day/night) cycles, a copolymer comprised of 70\% 3-hydroxybutyrate and 30\% 3-hydroxyvalerate (PHB-V) was produced within the bacteria. PHB-V has physical properties similar to polyethylene. A cast film of PHB was completely biodegraded within 15 days by indigenous bacteria from a local pond.
\end{abstract}




\title{
EVALUATION OF DISCRETE CELLULASE ENZYME ACTIVITIES FROM ANAEROBIC DIGESTER SLUDGE FED A MUNICIPAL SOLID WASTE FEEDSTOCK
}

\author{
C.J. Rivard, R.A. Nieves, N.J. Nagle, and M.E. Himmel \\ Applied Biological Sciences Branch \\ Alternative Fuels Division \\ National Renewable Energy Laboratory \\ Golden, CO 80401
}

\begin{abstract}
Anaerobic digestion of municipal solid waste (MSW) represents a waste disposal option that results in the production of a gaseous fuel (methane) and an organic residue suitable for use as a soil amendment. The rate-limiting step in this process is the hydrolysis of polymeric substrates, such as cellulose. However, only limited information exists concerning the hydrolytic capacity of anaerobic digestion systems. We have previously reported methods for extraction of active hydrolytic enzyme activities from digester sludge solids. Additionally, we have determined the operational optima for selected digester-resident cellulase enzymes. In this study, discrete cellulase enzyme activities were examined utilizing both preparative native-polyacrylamide gel electrophoresis (PAGE) and preparative isoelectric focusing. The identification of isolated cellulases in gels was based on zymogram staining for carboxymethyl cellulose (CMC) activity. These endoglucanases were further fingerprinted by obtaining sodium dodecyl sulfate (SDS)-PAGE derived molecular weights and isoelectric pHs.
\end{abstract}




\title{
COMPOSITIONAL CHANGES OF ADSORBED CELLULASES DURING CELLULOSE HYDROLYSIS
}

\author{
A.H.C. Yu and J.N. Saddler \\ University of British Columbia \\ Faculty of Foresty \\ Vancouver, B.C. Canada V6S 2L9
}

The adsorptive characteristics of cellulase components on cellulosic materials were studied to better understand the mechanism of enzymatic hydrolysis of cellulose. In order to follow the adsorption and desorption of the individual components of the Trichoderma reesei cellulase complex during hydrolysis, a chromatofocusing column (Mono-P) in a fast protein liquid chromatography (FPLC) system was used to identify these CC. onents. Using FPLC, Celluclast (NOVO) was separated into 22 protein peaks; then each peak was characterized in terms of its $\mathrm{pl}, \mathrm{M}$. .W., and enzymatic activities. The separated protein peaks were found to be comprised of 1 to 4 protein bands by SDS-PAGE. Endoglucanase, exocellobiohydrolase, xylanase, and Bglucosidase activities in each peak were determined by standard assays and by zymographic techniques with chromogenic and fluorogenic substrates. Preliminary studies on the adsorption of Celluclast on Avicel and acid-swollen Avicel have shown that there was a quantitative rather than qualitative difference between the two substrates. More of each cellulase component can adsorb to the acid-swollen Avicel than to Avicel. All but one of the FPLC-resolved peaks were shown to adsorb onto both substrates. The cellulase components that remain on the substrates during hydrolysis will be described. 


\title{
USE OF A CELLULOSE-BINDING DOMAIN TO MEASURE THE ACCESSIBILITY OF VARIOUS CELLULIJSIC SUBSTRATES TO CELLULASES
}

\author{
D. Lee, K.K.Y Wong, A.Y.C. Yu, J.N. Saddler, A. Warren, \\ D. Killbu $n$, and N. Gilkes \\ University of British Columbia \\ Vancouver, B.C. Canada V6S 2L9
}

The susceptibility of a cellulosic substrate to enzymatic hydrolysis depends on the ability of cellulases to bind to cellulose. In lignocellulosic substrates, hemicellulose and lignin not only form a physical barrier restricting access to cellulose, but may also form adsorb cellulases. CBDcex is the cellulose-binding domain from an exoglucanase/xylanase produced by Cellulomonas fimi. Since CBDcex binds to substrates without hydrolysing them, it was used as a probe to investigate the binding capacity of various cellulosic substrates. The maximum amount of CBDcex that bound to sites on the substrate was used as a measure of accessibility of cellulases to the substrate. When commercial cellulose substrates were used, initial results showed that the maximal initial hydrolysis rate obtained by cellulases from Trichoderma reesei (Novo) could be correlated with maximal binding of CBDcex. Adsorption of CBDcex to lignocellulosic substrates was also determined to see if these results could be extended to include substrates containing lignin and hemicellulose. 
Poster 49

\title{
OVERPRODUCTION OF THE CLONED XYLANASES FROM ALKALOPHILIC THERMOPHILIC BACILLUS
}

\author{
A. Shendye, R. Gaikaiwari, and M. Rao \\ Division of Biochemical Sciences \\ National Chemical Laboratory \\ Pune 411008 INDIA
}

\begin{abstract}
Xylanases find potential application in paper and pulp industry and for the complete conversion of cellulosic biomass to useful feedstocks. Due to the biotechnological importance of the xylanases, we have applied the recombinant DNA approaches for cloning of the xylanase gene and to understand the gene regulation. A 6.5 $\mathrm{kb}$ Hind III fragment from alkalophilic thermophilic Bacillus (NCIM 59) coding for two xylanases has been cloned and the expression in $E$. coli and B. subtilis A8 has been studied. The recombinant $B$. subtilis A8 produced five times higher xylanase activity $(0.15 \mathrm{U} / \mathrm{ml} / 18 \mathrm{~h})$ as compared to that of $E$. coli recombinant $(0.03 \mathrm{U} / \mathrm{ml} / 18 \mathrm{~h})$; which is lower than that of the parent organism $(50 \mathrm{U} / \mathrm{ml} / 48 \mathrm{~h})$. The host used in these studies was a xylanase negative mutant. The mutation might be accompanied by the overexpression of the xylanase gene repressor, possibly interfering with the expression of the cloned xylanase gene (Enz. Microbial Tech. 15: in press).
\end{abstract}

In order to overproduce the xylanases plasmid pLP 1202 carrying the $6.5 \mathrm{~kb}$ insert was transformed in the Bacillus subtilis M III. The host B. subtilis M III produces low level of xylanase activity, but these xylanases do no react with the antibodies raised against the purified xylanase $(\mathrm{Mr} 15,000)$ from the alkalophilic thermophilic Bacillus. The transformants were chloramphenicol resistant and produced $3.0 \mathrm{U} / \mathrm{ml} / 18 \mathrm{~h}$ of xylanases that reacted with the antibodies confirming that they were coded by the insert. In another approach, the xylanase gene copy number of the alkalophilic thermophilic Bacillus was doubled by the homologous recombination. The enzyme production was increased to $75-90 \mathrm{U} / \mathrm{ml} / 24 \mathrm{~h}$.

The genetic engineering approaches for the overproduction of xylanases are discussed in the present paper with special reference to the application of the recombinants at industrial level. 


\title{
AUTOTROPHIC GROWTH OF DESULFOTOMACULUM ORIENTIS WITH REDUCTION OF SULFUR DIOXIDE
}

\author{
C.-M. Lee and K.L. Sublette * \\ Center for Environmental Research \& Technology \\ University of Tulsa \\ Tulsa, OK 74104
}

We have previously proposed that the concentrated sulfur dioxide $\left(\mathrm{SO}_{2}\right)$ stream obtained from certain regenerable processes for flue gas desulfurization, such as the copper oxide process, may be split with two-thirds of the $\mathrm{SO}_{2}$ reduced to hydrogen sulfide $\left(\mathrm{H}_{2} \mathrm{~S}\right)$ by contact with a culture of sulfate-reducing bacteria. The resulting $\mathrm{H}_{2} \mathrm{~S}$ could then be combined with the remaining $\mathrm{SO}_{2}$ and used as feed to a Claus reactor to produce elemental sulfur.

It has been demonstrated that the sulfate-reducing bacterium Desulfotomaculum orientis can be grown in batch cultures on elemental hydrogen $\left(\mathrm{H}_{2}\right)$ as an energy source, carbon dioxide $\left(\mathrm{CO}_{2}\right)$ as a carbon source and $\mathrm{SO}_{2}$ as a terminal electron acceptor. Complete reduction of $\mathrm{SO}_{2}$ to $\mathrm{H}_{2} \mathrm{~S}$ was observed with $1-2 \mathrm{~s}$ of gas-liquid contact time. The stoichiometry of $\mathrm{SO}_{2}$ reduction with $\mathrm{H}_{2}$ as the electron donor has been determined and batch reactors have been optimized with respect to percent conversion of $\mathrm{H}_{2}$ in the gas feed via gas recycle.

"Corresponding author. 


\title{
EVALUATION OF N2-FIXATION BY STEM AND ROOT NODULES IN SESBANIA ROSTRATA
}

\author{
S. Rajavelu, V.C. Saralabai, and M. Vivekanandan \\ School of Life Sciences \\ Bharathidasan University \\ Tamilnadu, India
}

\begin{abstract}
Sesbania rostrata is the most popular green manure legume in Tamilnadu, India. S. rostrata produces both stem and root nodules. Hitherto, no experiments were performed to assess the superiority of one kind of nodule over the other. The levels of nitrogenous compounds like $\mathrm{NO}_{2}, \mathrm{NO}_{3}$, total $\mathrm{N}_{2}$, free amino-acids, total soluble proteins, allantoin and allantoic acid were determined in both the stem and root nodules during winter and summer. During winter, the stem nodules possessed heavy deposition of these compounds than the root nodules. On the other hand, during the summer the root nodules accumulated substantial levels of these nitrogenous compounds. Irrespective of the summer or winter, the activities of oxygen scavenging enzymes did not show any striking difference. In a similar way, the activities of $\mathrm{N}_{2}$ ase and $\mathrm{NR}$ were higher in stem nodules during the winter and the trend was reversed during summer; root nodules having higher $\mathrm{N}_{2}$ ase and NRA. In consonance with the higher activities of enzymes and gorging of nitrogenous compounds, calorific values were more in the stem nodules during winter. As regards rhizobial population, the root nodules always contained more Rhizobia than the stem nodules. The efficiency of the stem and root nodules to fix more nitrogen and synthesize nitrogenous compounds is seasonal. In summer the entire role of $\mathrm{N}_{2}$ fixation seemed to be borne by root nodule rhizobia only, as stem nodules during this period are hardly formed and sparsely distributed.
\end{abstract}




\title{
THE MECHANISM OF INCREASING CELLULASE BIOSYNTHESIS RATE IN MYCELIAL FUNGUS BY L-SORBOSE
}

\author{
D. Wang, Y.-b. Qu, and P.-j. Gai \\ Institute of Microbiology \\ Shandong University \\ Jinan, China
}

\begin{abstract}
Cellulase synthesis in Trichoderma reesei C30 and Trichoderma pseudokoningii S38 increased by L-Sorbose was studied. In a glucose -Mandel's salt medium supplied with 5\% Sorbose, both strains had a two to four-fold increase of the activities of filter paper and endoglucanase synthesis over the unsupplemented control on day 2. The presence of Sorbose in the growth medium resulted in the inhibition of mycelium growth and this factor seemed to be correlated to increasing the synthesis rate of extracellular cellulase. At the same time, however, the uptake rate of glucose and the subcellular distribution of cellulase did not change obviously. Cycloheximide can completely remove the effect on cellulase synthesis showed that the effect on cellulase by Sorbose was involved de novo synthesis. Sorbose can be used as the sole carbon source only in the presence of organic nitrogen, such as polypeptone or yeast extract. On the other hand, Sorbose cannot affect the level of $\beta$-glucosidase, which indicated that the regulation mechanism of $\beta$-glucosidase synthesis is not the same as that of the exo-and endoglucanase in these two strains.
\end{abstract}




\title{
PHOTOENHANCED ANAEROBIC DIGESTION OF ORGANIC ACIDS INTO METHANE
}

\author{
P.F. Weaver and P.C. Maness
}

\section{National Renewable Energy Laboratory Golden, CO 80401}

The slow steps of the soluble reactions that occur in anaerobic digestion are the conversion of organic acids into $\mathrm{H}_{2}, \mathrm{CO}_{2}$, and acetic acid and the conversion of acetic acid into methane. Undoubtedly they are slow due to energetic constraints. Photosynthetic bacteria utilize solar energy anaerobically to generate ATP, which can then drive energetically unfavorable reactions. Under conditions of low intensity illumination, some strains of photosynthetic bacteria produced $\mathrm{H}_{2}$ from organic acids, including acetic acid, at partial pressures well above the $\mathrm{K}_{\mathrm{s}}$ for $\mathrm{H}_{2}$ of methanogenic bacteria. The photosynthetic bacteria appear to photoassimilate the organic acids into endogenous sugars or sugar precursors that are subsequently converted through dark reactions into fermentation products, including $\mathrm{H}_{2}$ and $\mathrm{CO}_{2}$, which are rapidly scavenged by methanogenic bacteria. Repetitive light/dark cycles depleted organic acid pools and enhanced methane production. In mixed culture with methanogenic enrichments or in defined co-culture with non-aceticlastic methanogenic bacteria, photosynthetic bacteria were capable of facilitating the nearly complete conversion of propionic, butyric, or acetic acids into methane with low levels of light energy input. The interaction is thought to be a natural commensalism between photosynthetic and methanogenic bacteria. 


\title{
REMOVAL OF INHIBITION BY AMMONIUM ION IN NITROGENASE-DEPENDENT $\mathrm{H}_{2}$ EVOLUTION OF MARINE PHOTOSYNTHETIC BACTERIUM, RHODOPSEUDOMONAS SP. STRAIN W1S
}

\author{
K. Yagi $i^{a}$, I. Maeda ${ }^{a}$, K. Idehara ${ }^{a}$, Y. Miura ${ }^{a}$, \\ T. Akano ${ }^{b}$, K. Fukatu ${ }^{b}$, Y. Ikuta ${ }^{b}$, and H.K. Nakamura ${ }^{c}$ \\ a Osaka University \\ Osaka 565, Japan \\ ${ }^{b}$ Kansai Electric Power Company, Inc. \\ ${ }^{\mathrm{c}}$ Mitsubishi Heavy Industries, Ltd.
}

We have been studying stable biophotolysis system with an alternating light/dark cycle using green alga and photosynthetic bacterium. The photosynthetic bacterium plays a role in the system to produce hydrogen from organic compounds released by green alga into dark anaerobic fermentation broth. The alga rapidly degrades intracellular starch to evolve hydrogen in the presence of $1 \mathrm{mM} \mathrm{nH} 4 \mathrm{Cl}$. But the ammonium ion in the fermentation broth inhibits the subsequent hydrogen evolution by photosynthetic bacterium. In this study we tried to isolate mutant in which hydrogen evolution is not inhibited by ammonium ion in the algal fermentation broth.

A marine photosynthetic bacterium, Rhodopseudomonas sp. strain W1S was treated with ethylmethane sulfonate and cultivated in the medium containing L-methionine-sulfoximine (MXS) for the purpose of obtairing mutants having non-repressible nitrogenase. We isolated mutant $C R-8$ which could evolve hydrogen in the presence of $1 \mathrm{mM} \mathrm{NH} 4 \mathrm{Cl}$. We also found that hydrogen evolution in the wild type strain was not inhibited by $1 \mathrm{mM} \mathrm{NH} 4 \mathrm{Cl}$ in the presence of excess amount of substrate. Therefore, the removal of inhibition in CR-8 might not be derived from the regulation of nitrogenase but from the change of electron flow or energy supply to nitrogenase for the hydrogen production. 


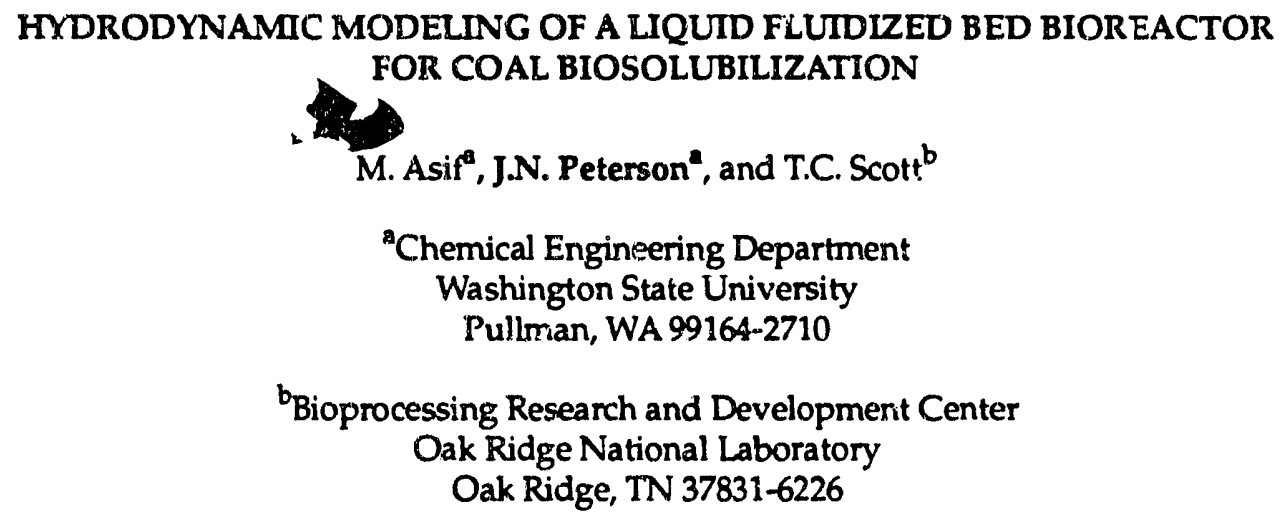

The modeling of hydrodynamics of an advanced fluidized bed bioreactor for coal biosolubilization poses some challenging problems. The progressive solubilization of coal particles in the fluidized bed not only makes the system inherently dynamic in nature but also, unlike conventional fluidized beds which contain only mono-sized particles, leads to the presence of coal particles in the bed which widely differ in the size. This situation is further complicated by the fact that the size of the particles gradually decreases with time due to the solubilization. Once the liquid superficial velocity exceeds the particle terminal velocity, the particles start to elutriate from the bed.

These issues which are being addressed in the present study are key for an accurate hydrodynamic characterization of the fluidized bed bioreactor and its subsequent design arid scale-up. Additionally, experiments are underway to accurately determine the concentration profiles of particles in the fluidized bed using both the pressure gradient method and a non-intrusive particle sampling technique. 


\title{
CONVERSION OF HYDROGEN SULFIDE TO ELEMENTAL SULFUR BY CHLOROBIUM THIOSULFATOPHILUM IN A CSTR WITH A SULFUR SETTLING SEPARATOR
}

\author{
R. Basu, S. Ramakrishnan, E.C. Clausen, and \\ J.L. Gaddy \\ University of Arkansas \\ Department of Chemical Engineering \\ Fayetteville, AR 72701
}

Chlorobium thiosulfatophilum may be used for bioconversion of hydrogen sulfide to elemental sulfur or sulfate. Sulfur is the preferred product due to problems in the disposing of sulfate. A CSTR with a sulfur settling separator has been used to preferentially produce and recover elemental sulfur. The simple nutritional requirements of the bacterium and differences in densities and average cell and sulfur particle sizes make a CSTR with a sulfur settling separator attractive. A bench scale study has been carried out to determine the optimum process conditions to maximize $\mathrm{H}_{2} \mathrm{~S}$ conversion, cell growth, elemental sulfur production, and to minimize sulfate production. The results of this study are presented and discussed. 
HIGH YIELD SHAKE FLASK FERMENTATION OF XYLOSE TO ETHANOL

\author{
B.L. Boynton and J.D. McMillan
}

\title{
National Renewable Energy Laboratory \\ Golden, CO 80401
}

The fermentation of D-xylose to ethanol at high yield is an important component in the development of an economical process for the conversion of biomass to ethanol at NREL. A characteristic of xylose-fermenting yeasts such as Pichia stipitis is that low levels of oxygenation are required to achieve high yield ethanol production. As shown by experiments in which the initial xylose zuncentration was varied at a fixed volume ratio of 0.25 (culture volume to total flask volume), high aeration levels lead to extensive cell mass production and concomitant low product yield. Increasing the volume ratio reduces the level of aeration and enables higher ethanol yields to be attained. Experiments in which the volume ratio was varied from 0.33 to 0.75 demonstrate that volume ratios greater than 0.5 create conditions of oxygen limitation such that near theoretical ethanol yields can be attained. 


\title{
TEMPERATURE DEPENDENT KINETICS OF ETHANOL FERMENTATION USING A SELF-AGGREGATING SACCHAROMYCES UVARUM
}

\author{
C.S. Chen ${ }^{a}$, S.I. Wang ${ }^{a}$, L.G. Chen ${ }^{a}$, and L.F. Chen ${ }^{b}$ \\ ${ }^{a}$ Department of Food Engineering \\ Da-Yeh Institute of Technology \\ Chang-Hwa, Taiwan \\ ${ }^{b}$ Food Science Department \\ Purdue University \\ West Lafayette, IN 47907
}

A self-aggregating Saccharomyces uvarum formed large stable aggregates in a tower fermentor. The temperature dependence of the fermentation and growth kinetics were studied within temperature ranges between $20^{\circ} \mathrm{C}$ to $45^{\circ} \mathrm{C}$. Sugar concentrations ranging from $10 \%$ to $25 \%(\mathrm{w} / \mathrm{v})$ were used as fermentation medium. Molasses and dextrose syrup from com were used as carbon sources. The effectiveness factor for the aggregates under various sugar concentrations and temperatures were studied. 
Poster 59

\title{
CELLULOSE HYDROLYSIS USING ZINC CHLORIDE AS A SOLVENT AND CATALXST
}

\author{
N.J. Cao, Q. Xu, C.S. Gong, and L.F. Chen \\ Food Science Department \\ Purdue University \\ West Lafayette, IN 47907
}

Cellulose hydrolysis was carried out in a gel state in a zinc chloride solution. The zinc chloride/cellulose ratio was 1.5 . The hydrolysis rate at various temperatures and its products and yields are reported. The methods for recycling zinc chloride were also studied. 
Poster 60

\title{
CELLULASE: AND XMLANASE PRODUCTION BY ASPERGILLUS SP. G-393
}

\author{
S.I. Wang , L.G. Chen ${ }^{a}$, C.S. Chen ${ }^{a}$, and L.F. Chen ${ }^{b}$ \\ ad Department of Food Engineering \\ Da-Yeh Institute of Technology \\ Chang-Hwa, Taiwan \\ ${ }^{b}$ Food Science Department \\ Purdue University \\ West Lafayette, IN 47907
}

\begin{abstract}
Agriciltural wastes were used as the substrate for culturing of Aspergillus sp. G-393. This strain produces xylanase and cellulase in a medium containing $2.5 \%$ rice bran, $2.5 \%$ sugarcane bagasse, $0.3 \%$ pulp, $0.1 \% \mathrm{~K}_{2} \mathrm{PO}_{4}$, and $0.05 \% \mathrm{MgSO}_{4} .7 \mathrm{H}_{2} \mathrm{O}$.
\end{abstract}

The optimal growth conditions for the production of cellulase was $\mathrm{pH} 3$ at $60^{\circ} \mathrm{C}$ and for xylanase was $\mathrm{pH} 5$ and $60^{\circ} \mathrm{C}$. Maximal cellulase activity occurred in a pH ranging from 3 to 9 . The enzyme maintained its activity at $60^{\circ} \mathrm{C}$. Maximal xylanase activity was obtained at a $\mathrm{pH}$ range from 4 to 10 , and the enzyme activity is stable at $50^{\circ} \mathrm{C}$. 


\title{
ETHANOL FERMENTATION IN A TOWER FERMENTOR USING SELF-AGGREGATING SACCHAROMYCES UVARUM
}

\author{
C.S. Chen ${ }^{a}$, C.S. Gong ${ }^{b}$, and L.F. Chen ${ }^{b}$ \\ ${ }^{a}$ Department of Food Engineering \\ Da-Yeh Institute of Technology \\ Chang-Hwa, Taiwan \\ ${ }^{\text {b} F o o d ~ S c i e n c e ~ D e p a r t m e n t ~}$ \\ Purdue University \\ West Lafayette, IN 47907
}

Ethanol fermentation was carried out in a tower fermentor with a self-aggregating Saccharomyces uvarum which forms large aggregates with diameter of 2-3 mm. In the fermentor, cell density was $100 \mathrm{~g}$ dry cells per liter. Ethanol productivity was $53 \mathrm{~g} / \mathrm{l} / \mathrm{h}$ at a dilution rate of $0.7 \mathrm{~h}^{-1}$, using corn syrup as substrate. The sugar concentration in the feed was $15 \%(w / v)$. When canesugar black strap molasses $(12 \% \cdot w / v)$ was used as substrate, ethanol productivity was $17 \mathrm{~g} / 1 / \mathrm{h}$ at a dilution rate of $0.35 \mathrm{~h}^{-1}$. Ethanol yield was $96 \%$ and $92 \%$ of the theoretical values in corn syrup and sugar cane black strap molasses, respectively. No loss of fermentative activity in the tower had been observed in three months. Fermentation at various dilution rates was also reported. 
Poster 62

FIGHT AGAINST BACTERIAL CONTAMINATION IN INDUSTRIAL ALCOHOLIC FERMENTATIONS

M. de Miniac

l'Union Nationale des Distillateurs d'Alcool

Paris, France

Withdrawn from program. 


\title{
CHEESE WHEY FERMENTATION FOR SINGLE CELL PROTEIN PRODUCTION AND POLLUTION POTENTIAL REDUCTION
}

\author{
A. E. Ghaly \\ Technical University of Nova Scotia \\ Halifax, Nova Scotia, Canada
}

Batch pilot scale aerobic fermenters of $5 \mathrm{~L}$ working volume, were used to study the kinetics of cheese whey fermeniation using the yeast Kluyveromyces fragilis for single cell protein production and pollution potential reduction. The fermentation process was successful in reducing the COD, total solids and ammonium nitrogen by $50 \%, 53 \%$, and $90 \%$, respectively. About $93 \%$ of lactose was utilized for growth whereas $7 \%$ of the lactose was utilized for energy. A yield of $0.78 \mathrm{~g}$ cell $/ \mathrm{g}$ lactose was achieved. The heat released varied from 6.0 to $8.9 \mathrm{KJ} / \mathrm{g}$ cell. 


\title{
EFFECT OF VARIOUS FACTORS ON THE EFFICIENCY OF ENZYMATIC CELLULOSE HYDROLYSIS IN THE INTENSIVE MASS TRANSFER REACTOR
}

\author{
A.v. Gusakov" , A.P.Sinitsyn ${ }^{a}$, I. Yu. Davydkin ${ }^{\text {, }}$ \\ and V. Yu. Davydkin \\ ${ }^{a}$ Department of Chemistry \\ M.V.Lomonosov \\ Moscow State University \\ Moscow 117234, Russia \\ ${ }^{\mathrm{b}}$ Research and Industrial Association DION Ltd. \\ 117607 Moscow, Russia
}

The Intensive Mass Transfer Reactor (IMTR) is a new concept of bioreactor that transforms the energy of electromagnetic field of special configuration into kinetic energy of ferromagnetic particles added to the reactor. Moving ferromagnetic particles provide a very intensive agitation of the reaction mixture. This is particularly important for the heterogeneous reaction system like cellulose-cellulases.

The effects of various factors (mass and shape of ferromagnetic particles, parameters of the electromagnetic field, enzyme and substrate concentrators, temperature, etc.) on the efficiency of enzymatic hydrolysis of microcrystalline cellulose, used as a model substrate, have been studied.

Under optimal conditions of the hydrolysis, up to $3.5 \%-6 \%$ of sugars were obtained in the IMTR after $0.5-2 \mathrm{~h}$ of the process with a productivity of $30-73 \mathrm{~g} / \mathrm{lh}$.

The enhancement of mobility of cellulolytic enzymes tightly absorbed on cellulose surface and some increase in cellulose susceptibility to cellulases seem to be the main reasons for a drastic improvement of the hydrolysis efficiency in the IMTR.

\footnotetext{
${ }^{1}$ Sinitsyn, A.P., Gusakov, A.V., Davydkin, I. Yu., Davydkin, V. Yu., and Protas, O.V. (1993), Biotechnol. Lett., in press.
} 
Poster 65

\title{
AQUEOUS BIPHASIC SYSTEMS FOR BIOLOGICAL PARTICLE PARTITIONING
}

\author{
D.T.L. Hawker ${ }^{a}$, R.H. Davis ${ }^{a}$, P. Todd ${ }^{a}$, and G. Johansson ${ }^{b}$ \\ a'Department of Chemical Engineering \\ University of Colorado \\ Boulder, CO 80309-0424 \\ ${ }^{b}$ Department of Biochemistry \\ University of Lund \\ S-221 00 Lund, Sweden
}

\begin{abstract}
Aqueous biphasic extraction can be used to separate particles from each other or from soluble materials. Examples of biological particles of interest include whole and broken cells, vesicles, and ribosomes. However, particles present in these extraction systems tend to partition to the interface over a period of time. It has been found that particles adsorb to the surface of phase droplets, and it is believed that they are carried to the interface between the two phases by these droplets. In order to understand this phenomenon, various factors related to the thermodynamics and fluid dynamics of particle partitioning are studied using BSA-coated latex spheres as model particles. These factors include the amount of solids added to the phase system, the particle size, the system composition, the phase volume ratio and the time of phase separation. It has been found that coated latex spheres are a well behaved model particle and that the spheres exhibit partitioning behavior similar to that of biological particles in these systems, such as partitioning over an extended period of time and responding to changes in salt and polymer content. These data are also compared to theoretical predictions which indicate that particle and drc plet interactions can account for the partitioning of particles to the interface.
\end{abstract}




\title{
DEVELOPMENT OF A BIPARTICLE FLUIDIZED BED BIOREACTOR FOR THE CONTINUOUS AND SIMULTANEOUS FERMENTATION AND PURIFICATION OF LACTIC ACID
}

\author{
E.N. Kaufman, S.P. Cooper, and B.H. Davison \\ Chemical Technology Division \\ Oak Ridge National Laboratory \\ Oak Ridge, TN 37831-6226
}

\begin{abstract}
A continuous biparticle fluidized bed reactor is developed for the simultaneous fermentation and purification of lactic acid. Previous efforts have demonstrated the use of a biparticle fluidized bed bioreactor for the fermentation and separation of lactic acid (Davison \& Thompson 1992 Appl. Biochem. Biotechnol. 34, 431-439). Batchwise addition of polyvinyl pyridine resin was shown to adsorb the acid, muderate the reactor $\mathrm{pH}$, and enhance the fermentation. Productivity in the unoptimized reactor was $\sim 4$ times that of the fluidized bed without resin addition. This work has investigated a variety of methods for the repetitive regeneration of the loaded resin using methanol, acetone, hot water, or vacuum. Solids handling procedures are developed for the continuous fermentation and purification of lactic acid with total recycle of the adsorbent resin. The system is demonstrated in a biparticle fluidized bed of immobilized Lactobacillus delbreuckii. Unlike conventional fermentation schemes, the biparticle fluidized bed does not require the addition of salts for reactor $\mathrm{pH}$ control and product separation as the inhibitory product is removed directly from the reactor. This minimizes process waste and enhances reactor efficiency.
\end{abstract}




\title{
STUDY OF COAL PARTICLE SEGREGATION IN A LIQUID FLUIDIZED BED: IN SITU VISUALIZATION USING FLUORESCENCE MICROSCOPY
}

\author{
E.N. Kaufman and T.C. Scott \\ Chemical Technology Division \\ Oak Ridge National Laboratory \\ Oak Ridge, TN 37831-6226
}

Liquid fluidized beds of small coal particles have been investigated for the biocatalytic solubilization/liquefaction of coal at near ambient temperatures. The hydrodynamic mechanisms governing the operation of such a reactor include the dispersivity of both the liquid and solid phases, the pressure drop across the column, and the axial segregation of coal particles due to differences in particle size and density. This work has undertaken the direct visualization of coal particles $(20-150 \mu \mathrm{m})$ in operating fluidized beds using fluorescence microscopy. Particle size distributions as a function of axial position yield information as to particle segregation versus flowrate and bed composition. The fluorescence technique has been developed and fully validated. Unlike conventional methods, the proposed technique yields direct quantitative statistics as to segregation, is non-invasive, does not require the coal particles to be altered in any manner, may be used at high solids concentrations, and may be used in operational reactors. Ongoing research will incorporate particle segregation, fluid and solid dispersion, and axial pressure drop into a fully predictive model of biocatalytic coal liquefaction reactor performance. 


\title{
IMMOBILIZATION OF INVERTASE ONTO A COPOLYMER OF METHACRYLAMIDE AND N,N'-METHYLENEBIS(ACRYLAMIDE) AND CHARACTERIZATION
}

\author{
C.-T. Huang and W.-C. Lee* \\ "Associate Professor \\ Department of Chemical Engineering \\ Chung Yuan Christian University \\ Chung Li, Taiwan
}

\begin{abstract}
Beads of copolymerized methacrylamide and $N_{,} N^{\prime}$-methylenebisacrylamide were prepared by means of the $\mathrm{W} / \mathrm{O}$ type suspension polymerization. The polymer was activated by various reagents and tested as a support for immobilizing invertase. The best procedure for enzyme immobilization was found to be the one when the polymer beads were previously modified with ethylene diamine at $90^{\circ} \mathrm{C}$ to yield the activated supports with $2 \mathrm{~m} \mathrm{~mol} / \mathrm{g}$ of amino density and then incubated with glutaraldehyde and enzyme. The kinetics of this immobilized invertase for sucrose hydrolysis were determined as $K_{m}=0.24 \mathrm{M}$ and $V_{\max }=8715 \mathrm{~mol} / \mathrm{min}$ g-support. The coupled invertase showed the same optimum $\mathrm{pH}$ value as the free enzyme. Whereas the optimum temperature was shifted from $50^{\circ} \mathrm{C}$ for free enzyme activity to $60^{\circ} \mathrm{C}$ for immobilized enzyme activity. A higher stability was noticed at high temperature. At $70^{\circ} \mathrm{C}$, the activity of immobilized invertase retained $60 \%$ of its maximum value, but the free enzyme activity retained on'y $15 \%$. These porous polymer beads were also tested for partial modification with $0.2 \mathrm{~N}$ sodium carbonate to introduce negative-charged carboxyl groups. The : ata potential of the beads gradually decreased from -2.4 to $-30.7 \mathrm{mV}$ when they were treated with the base for $4 \mathrm{hr}$. The influence of the charge density on the enzyme immobilization was also studied.
\end{abstract}




\title{
FED BATCH FERMENTATION OF SWEET SORGHUM CARBOHYDRATES TO ETHANOL BY A MIXED CULT JRE
}

\author{
V. Lezinou, P. Christakopoulos, D. Kekos, and B.J. Macris \\ Department of Chemical Engineering \\ National Technical University of Athens \\ Athens 15700 Greece
}

The direct conversion of swet sorghum carbohydrates (oligo- and polysaccharides) to ethanol by a mixed culture of Fusarium oxysporum F3, Saccharomyces cererisiae 2541 or Zymomonas mobilis CP4 in a fed batch fermentation system was studied. The first micmnrganism was grown aerobically and produced the enzymes required for the hydrolysis of polysacc!'arides to monomers while each one of the other two, in certain proportions with the first and in the same bioreactor, converted the monumers to ethanol under anaerobic conditions. Optimum ethanol concentrations as high as $75.5-83.6 \mathrm{~g} / 1$ and yields $31.2-32.2$ and $9.7-10 \mathrm{~g}$ ethanol $/ 100 \mathrm{~g}$ sorghum carbohydrates and stalks respectively were obtained making the process worthy of further investigation. 


\title{
ON THE MECHANISM OF DIRECT BIOCONVERSION OF SWEET SORGHUM CARBOHYDRATES TO ETHANOL: EFFECT OF CELLULOLYTIC ENZYMES
}

\author{
V. Lezinou, P. Christakopoulos, D. Kekos, and B.J. Macris \\ Department of Chemical Engineering \\ National Technical University of Athens \\ Athens 15700 Greece
}

The profile of cellulolytic enzymes, excreted during aerated growth of the fungus Fusarium oxysporum F3, affected the direct conversion of sweet sorghum polysaccharides to ethanol by a mixed culture of this fungus and Saccharomyces cerevisiar. 2541. At optimum enzyme activity and fermentation conditions yields as high as 41.2 and $12.8 \mathrm{~g}$ ethanol $/ 100 \mathrm{~g}$ sorghum carbohydrates and stalks respectively were obtained while the ethanol concentration was $51.7 \mathrm{~g} / \mathrm{l}$. Ethanol yield accounted for $191 \%$ of the theoretical yield based on sorghum oligosaccharides and was very promising for bio-ethanol production. 


\title{
BIOCONVERSION OF MSW TO LACTIC ACID BY LACTOBACILLUS SPECIES
}

\author{
T.A. McCaskey", S. Zhou ${ }^{\mathrm{a}}$, and R.C. Strickland ${ }^{\mathrm{b}}$ \\ a Auburn University \\ Auburn, AL 36849-5415 \\ bennessee Valley Authority \\ Muscle Shoals, AL 35660
}

\begin{abstract}
Approximately 240 million tons of municipal solid waste (MSW) are generated annually in the United States. Concerns about the environmental impact of MSW in landfills have contributed to the development of new or alternative strategies for MSW management. The major components of MSW are cellulosics (e.g., newsprint, wood, cardboard and yard waste) which can be converted to a variety of fuels and chemicals by microorganisms. Lactic acid, one of these chemicals, can be manufactured into polylactic acid (PLA) plastics and coatings, which are $100 \%$ degradable and have been approved for use by FDA.

Eight Lactobacillus cultures were evaluated for their ability to produce lactic acid from simple sugars and from acid-hydrolyzed MSW. Five cultures showed promise for lactic acid production. Effective treatments to remove microbial inhibitors from MSW, which also improve its buffering capacity, have been developed. The lactic acid yield and productivity from acid-hydrolyzed MSW are $65 \mathrm{mg} / \mathrm{mL}$ and $1.3-1.6 \mathrm{~g} / \mathrm{L} \cdot \mathrm{h}$, respectively Further improvements in lactic acid yield and fermentation efficiency are being explored. Fermentation parameters to maximize the production of lactic acid from acid-hydrolyzed MSW will be presented.
\end{abstract}


ARABINOSE UTILIZATION BY XYLOSE-FERMENTING YEAST AND FUNGI

\author{
J.D. McMillan and B.L. Boynton \\ National Renewable Energy Laboratory \\ Golden, CO $80401-3393$
}

Sugars solubilized upon dilute acid hydrolysis pretreatment of lignocellulosic biomass include the pentoses $D$-xylose and L-arabinose as well as the hexoses D-glucose, D-mannose and D-galactose. Although fermentation of xylose, glucose, mannose and galactose to ethanol is carried out by a variety of wildtype xylusefermenting yeast and fungi, arabinose fermentation has not been convincingly reported. To ascertain whether the ability to ferment L-arabinose to ethanol is likely to exist among such organisms, a variety of wildtype yeast and fungi were screened to evaluate their ability to ferment arabinose under oxygen-limited conditions when grown in defined minimal phosphate buffered YNB medium containing a mixture of arabinose, xylose and glucose. All of the yeast and some of the fungi consumed arabinose although significant fermentation of arabinose to ethanol was not observed for any of the strains tested. Arabitol was the major product formed from L-arabinose consumption by yeast and fungi, with yeast converting arabinose to arabitol at near theoretical yield ( $1 \mathrm{~mol}$ arabitol formed per mol arabinose consumed). These results indicate that inability to ferment arabinose is a widely conserved trait among xylose-fermenting yeast and fungi. Probable reasons for the inability of wildtype yeast and fungi to ferment $L$-arabinose to ethanol are discussed. 
Poster 73

\title{
PRODUCTION OF LACTIC ACID FROM LIGNOCELLULOSIC BIOMASS
}

\author{
N. Padukone, S. Schmidt, and B. Goodman \\ National Renewable Energy Laboratory \\ Golden, CO 80401
}

\begin{abstract}
Lactic acid, which is produced currently by both fermentation and chemical routes, could be an important raw material in the future for the production of biodegradable polymers. Past studies on the production of lactic acid via fermentation have focused mainly on sources of sugars such as sucrose, glucose, and lactose. Lignocellulosic biomass, which is available in abundance, can be a potentially cheap source of lactic acid and other chemicals. In an effort to investigate this, we have studied the production of lactic acid from pure substrates such as cellulose, glucose, and xylose. Various Lactobacillus strains and fermentation conditions have been examined for the efficient conversion of glucose and xylose. Experiments on simultaneous saccharification and fermentation (SSF) of cellulose to lactic acid have also been carried out using exogenously added cellulase enzyme and the microorganism. The results of our studies on these pure substrates will be presented and strategies for their application to real substrates will be discussed.
\end{abstract}




\title{
ON-LINE MONITORING OF FRESH-WEIGHTS IN CARROT HAIRY-ROOT CULTURES BY CONDUCTOMETRY
}

\author{
H.-H. Ko , D.-H. Park", B. Hwang ${ }^{b}$, and R.D. Tanner ${ }^{c}$ \\ ${ }^{a}$ Department of Biochemical Engineering \\ Chonnam National University \\ Kwangju, 500-757, Korea \\ bepartment of Biology \\ Chonnam National University \\ Kwangiu, 500-757, Korea \\ 'Department of Chemical Engineering \\ Vanderbilt University \\ Nashville, TN 37235
}

Use of conductivity change in the medium for the on-line monitoring of fresh-weights was investigated in cultures of carrot hairy-roots.

Estimation equation of fresh-weights $(X)$ by electric-conductivity $(Y)$ in bioreactor was as follows:

$$
X=\frac{(Y-0.613855)}{0.02243}(0.16 \leq Y \leq 0.71 \mathrm{mS} / \mathrm{cm})
$$




\title{
ACETONE-BUTANOL PRODUCTION FROM BIOMASS BY SIMULTANEOUS SACCHARIFICATION AND EXTRACTIVE FERMENTATION
}

\author{
M.M. Shah ${ }^{2}$ and Y.Y. Lee ${ }^{b}$ \\ ${ }^{a}$ University of Ilinois \\ Urbana, IL 61801 \\ bAuburn University \\ Auburn, AL 36849
}

The acetone-butanol production by simultaneous saccharification and extractive fermentation (SSEF) was investigated. The SSEF employing cellulase enzymes and Clostridium acetobutylicum has shown that both glycan and xylan fractions of pretreated aspen are concurrently converted into acetone and butanol. Continuous removal of the fermentation products from the bioreactor by extraction was proven to be a useful feature that allows long-term fed batch operation. The use of membrane in the extraction prevented the problems of phase separation and extractant loss. The enzymatic hydrolysis was found to be at the rate-limiting step in the integrated process. A glucose-limited condition therefore existed throughout the operation. The glucoselimited condition, however, induced high level acid production. Increase in substrate feeding as well as reduction of nutrient supply was found to be beneficial in suppressing the acid production thereby improving the yield of solvents. In the fed-batch operation, the butanol-to-acetone ratio in the product was increased significantly due to prolonged non-growth condition. 


\title{
Poster 76
}

\section{SOLID STATE FERMENTATION OF PETROCROP SPENT RESIDUES FOR PRODUCTION OF THE CELLULASE ENZYME BY WHEAT LITTER DECOMPOSING FUNGI}

\author{
D.K. Sharma $a^{a^{*}}$, M. Tiwari ${ }^{a}$, and B.K. Behera ${ }^{b}$ \\ ${ }^{a}$ Centre for Energy Studies \\ Indian Institute of Technology \\ Delhi, New Delhi-110016, India \\ bepartment of Biosciences \\ M.D. University \\ Rohtak-124001, India
}

Thirty-seven wheat litter fungi were isolated and examined for their ability to produce cellulolytic enzymes in solid state fermentation (SSF). Different types of petrocrop lignocellulosic spent residues were tested as low cost substrate for SSF process. Lignocellulosic spent residue obtained from Atrocarpus integrifolia was found to be the most suitable substrate for biosynthesis of cellulase enzyme through

SSF process. The activities of other enzymes produced were also tested. Maximum cellulase activities were shown by Penicillium chrysogenum. The SSF of spent residue with $P$. chrysogenum was found to be influenced by the levels of glucose, maltose, corn starch, sucrose, distillery effluent and $\mathrm{CaCl}_{2}$, in terms of extracellular enzyme protein production.

*Addressee for correspondence 


\title{
ALPHA AND GLUCOAMLYASE PRODUCTION IN ENDOMYCOPSIS CAPSULARIS MUTANTS BY SOLID STATE FERMENTATION
}

\author{
S. Singh, K.S. Bath, M. Singh, and S. Soni \\ Department of Microbiology \\ Guru Nanak Dev University \\ Amritsar 143005 India
}

\begin{abstract}
Nine mutants $\left(V_{1}\right.$ to $\left.V_{8}, V_{22}, V_{55}\right)$ and four NTG mutants $\left(N_{1}\right.$ to $\left.N_{4}\right)$ were obtained from parental strain of Endomycopsis capsularis. Mutants after their primary screening by plate assay and secondary screening by quantitative assay were subjected to submerged fermentation for profile studies. Mutant $V_{22}$ exhibited maximum alphaamylase production after $12 \mathrm{~h}$ and peak levels of glucoamylase by mutant $V_{55}$ after $20 \mathrm{~h}$. All the mutants were again tested for enzyme production by solid state fermentation technique. Again maximum alphaamylase production was observed in mutant $V_{22}$, but glucoamylase production was exhibited by $V_{5}$ mutant. A comparative profile studies by solid state fermentation on different starchy substances, i.e., com flour, potato, wheat flour and wheat bran showed that wheat bran is the best for both alpha and glucoamylase production.
\end{abstract}

Effects of various parameters on amylase production were optimized. A decrease in moisture content from $30 \%$ to $60 \%$ increased the alpha as well as glucoamylase production. Supplementation of maltose $(20 \% \mathrm{w} / \mathrm{w})$ and glucose $(20 \% \mathrm{w} / \mathrm{w})$ in corn flour substrate had negative effect on both the enzymes while starch, wheat bran and wheat flour increased the amylase activity. Nitrogen sources like yeast nitrogen base, yeast extract, peptone and sodium nitrate when added to the corn flour increased the enzyme activity except sodium nitrate which depressed the amylase activity slightly. Metallic salts like potassium dihydrogen phosphate, magnesium sulphate, sodium chloride, calcium chloride and cobalt chloride when added to corn flour increased alpha and glucoamylase activities, but these salts when used in combination with yeast extract and peptone, a high increase in the alpha and glucoamylase activities was observed. 


\title{
ETHANOL PRODUCTION FROM LIGNOCELLULOSIC BIOMASS: EVALUATION OF SSF CONDITIONS AND PARAMETERS
}

\author{
T.K. Smith and G.P. Philippidis
}

\author{
National Renewable Energy Laboratory \\ Golden, CO 80401
}

\begin{abstract}
Ethanol, a promising alternative fuel, can be produced biochemically from abundantly available lignocellulosic biomass, such as energy crops, agricultural by-products, forestry residues, pulp and paper waste streams, and municipal solid waste. The simultaneous saccharification and fermentation (SSF) process is currently considered the best means for biomass conversion to ethanol. The SSF operation combines the enzymatic hydrolysis of cellulose to glucose, catalyzed by cellulase, with the fermentation of glucose to ethanol. For the biomass conversion technology to become economically viable, the performance of SSF needs to be enhanced. This work summarizes recent studies of the relationship between key SSF parameters/conditions and ethanol yield. The effects of fermentation conditions, such as $\mathrm{pH}$, temperature, inoculum size and age, and agitation, growth medium, biomass concentration, and cellulase enzyme concentration were evaluated in shake flasks and stirred tank bioreactors, using factorial experimental design techniques.
\end{abstract}




\title{
FERMENTATIONS BY INCLUDED YEASTS IN DOUBLE LAYORED ALGINATE BEADS
}

\author{
P. Taillandier", M.L. Delia-Dupuy ${ }^{a}$, C. Sanchez ${ }^{c}$, and P. Strehaiano ${ }^{b}$

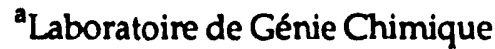 \\ CNRS URA 192 \\ Toulouse-Cedex, France \\ b Lallemand Inc. \\ Chemin de la Ménude \\ 31770 Colomiers France \\ 'Laboratoire d'Etude et d'Analyse des Procédés \\ ENSIGC 18, Chemin de la Loge \\ 31078 Toulouse-Cedex France
}

High cellular concentrations are a good way to increase the reaction rates of a biological process. Different methods are available to reach such concentrations in the reactor: immobilization, encapsulation, cell recycling...

Among these, previous works showed that inclusion offers good abilities. Nevertheless, with this device, the microorganisms may be released in the medium. To avoid this phenomenon, we propose a new way of inclusion in double layored beads.

These beads consist of a sphere of alginate and yeasts surrounded by a sterile layer of alginate. By this mean, the microorganisms stay into the beads.

This process was studied with yeasts for different fields of applications:

- Alcoholic fermentation in closed vessels:

Production of sparkling wines involves a step of fermentation into bottles and at the end the removal of yeasts is very expensive. Included yeasts are an efficient way to carry on the fermentation and to make the recovery of the microorganism easier.

- Deacidification in wine making:

Schizosaccharomyces yeasts able to remove malic acid from wines and grape must with great efficiency can be included in alginate beads in order to improve deacidification rates. The beads can be used either in batches or in continuous runs. We designed and tested a bioreactor allowing the continuous demalication by including Schizosaccharomyces. 


\title{
A TWO ZONE MIXING MODEL FOR DESCRIBING THE KINETICS OF A BATCH PECTIN-PECTINASE REACTION PROCESS
}

\author{
W. Tseng, A. Prokop, and R.D. Tanner
}

\author{
Chemical Engineering Department \\ Vanderbilt University \\ Nashville, TN 37235
}

\begin{abstract}
In order to account for spatial differences in the colloidal/solid pectin substrate, the batch reaction with pectinase was modelled with a two zone model. Imperfect mixing was, thus, able to consider early time concentrations of the pectin in the zone into which it is initially added. This isothermal liquid system is described by the non-linear single intermediate enzyme reaction configuration under various mixing rates (expressed by changes in the dilution rate, D). The interesting time trajectories are described in terms of the early time transients and the late time stationary state profiles. That latter profile can be described by the Briggs-Haldane Equation (for $\mathrm{E}_{0} / \mathrm{Km}$ small) or the Michaelis-Menten Equation (for $\mathrm{E}_{0} / \mathrm{Km}$ large), where $\mathrm{E}_{0}$ is the initial enzyme concentration and $\mathrm{Km}$, the Michaelis constant.
\end{abstract}




\title{
BIOCONVERSION OF VANILLIN TO VANILLIC ACID IN ONE- AND TWO-PHASE SYSTEMS
}

\author{
G. Baré, V. Delaunois, R. Rikir, and P.H. Thonart \\ Centre Wallon de Biologie Industrielle \\ Université de Liège \\ F.S.A.Gx, Sart-Tilman, B40 \\ 4000 Liège, Belgium
}

Pseudomonas fluorescens strain BTP9 is used as biocatalyst to produce vanillic acid from vanillin.

To optimize this bioconversion, various two-phase reactors are investigated and compared with the corre sponding monophasic systems. This paper also reports the influence of culture parameters on the bioconversion yield and productivity.

With a two-phase reactor (PEG 17\% - $\mathrm{KH}_{2} \mathrm{PO}_{4} 18 \%$ ), the vanillic acid concentration reaches, after $24 \mathrm{~h}$, in the PEG rich phase, $0.48 \mathrm{~g} / \mathrm{L}$ (conversion yield: $31 \%$ ) and, in the $\mathrm{KH}_{2} \mathrm{PO}_{4}$ rich phase, $0.04 \mathrm{~g} / \mathrm{L}$ (conversion yield: 23\%) while vanillic acid is not detected with the one-phase reactor, in the same conditions.

A water-dodecanol system is also set up. Two characteristics of this reactor are its high cell density and the entrapping of the cells in alginate beads. With this kind of reactor, the vanillic acid productivity is increased $(3.4 \mathrm{~g} / \mathrm{L} / \mathrm{d})$ in relation to the monophasic reactor, and the conversion rate is nearly $80 \%$. The effect of the cell density, the cell immobilization and the substrate concentration on the vanillic acid yield and productivity is discussed. 


\title{
SIMULATION MODEL (METHANE) AS A TOOL OF EFFECTIVE BIOGAS PRODUCTION DURING ANAEROBIC CONVERSION OF COMPLEX ORGANIC MATERIAL
}

\author{
V.A. Vavilin, V.B. Vasiliev, S.V. Rytow, and A.V. Ponomarev \\ Water Problems Institute \\ Russian Academy of Sciences \\ Novo-Basmannaja, Russia
}

Modeling studies are important because real experiments in anaerobic processes are very lengthy, labor intensive, and expensive. User friendly simulation model "Methane" can be applied for research of anaerobic sludge and waste water digestion. For a few minutes in IBM PC AT computer user obtains the dynamic behavior of anaerobic system during tenths of days. Hydrolysis, acidogenesis, and methanogenesis are included in the model as well as continuous flow and batch regimes, constant biomass concentration stationary regime or constant biomass residence time, constant or changeable organic loading, dissolved or particulate substrates in carbohydrates, proteins and lipids forms, granulated sludge or individual hydrolytic microorganisms.

The basic model includes two groups of acidogenic bacteria, synthropic bacteria, acetate utilizing methanogenic bacteria, hydrogen utilizing methanogenic bacteria and two sulphate-reducing groups of bacteria. Mass exchange process between gas phase and liquid is considered. Influence of environmental factors like temperature and $\mathrm{pH}$ is taken into account as well as inhibition of bacteria growth by the products of metabolism (dissolved hydrogen, non-ionized forms of hydrogen sulphide, ammonium nitrogen, higher carbonic acids).

By color monitor graphics user can analyze fast many anaerobic digesters disturbances including acidification, inhibition effects, environmental influence. 


\title{
SSF COMPARISON OF SELECTED WOODS FROM SOUTHERN SAW MILL
}

\author{
T.B. Vinzant, L.R. Ponfick, N.J. Nagle, T.I. Ehrman, K.M.Magill, \\ J.B. Reynolds", and M.E. Himmel
National Renewable Energy Laboratory
Golden, CO 80401 \\ South Point Ethanol \\ South Point, $\mathrm{OH} 45680$
}

\begin{abstract}
Simultaneous saccharification and fermentation (SSF) is recognized as an effit ient approach to the cost effective conversion of biomass to fuel ethanol. This methodology takes advantage of the relief in end-product inhibition realized by conducting cellulose hydrolysis and glucose fermentation in the same rvell-stirred vessel. In this study, fifteen species of hard and soft woods were collected from saw mills located in the Appalachian region. These wood sampies were air dried to 8-10\% moisture, pretreated using a rilute sulfuric acid cooking scheme at $160^{\circ} \mathrm{C}$, exhaustively washed, and applied to SSF with Sacciaromyces cerevisiae D5A. Although the glucan content of each wood was found to be relatively invarias throughout the sampli, tested, hemicellulosic sugar and lignin contents were unique tr, each wood. These, and other differences in chemical composition, were related to resulting ethanol yields irom SSF.
\end{abstract}




\title{
PERFORMANCE OF A FLUIDIZED BED REACTOR WITH DMMOBILIZED ENZYME
}

\author{
G.M. Zanin, L.M. Kambara, L.P.V. Calsavara, and F.F. de Moraes \\ Maringá State University \\ Chemical Engineering Department \\ $87020-900$ - Maringá - Parana - Brazil
}

The saccharification of amylase liquefied starch solution $(30 \% \mathrm{w} / \mathrm{v})$ was carried out at $\mathrm{pH} 4.5$ and $45^{\circ} \mathrm{C}$, with glucoamylase immobilized in controlled pore silica (dp: $0.439 \mathrm{~mm}, \rho p: 0.939 \mathrm{~g} / \mathrm{cm}^{3}$, mean pore diameter: $37.5 \mathrm{~nm}$, enzymatic activity: $676.8 \mathrm{U} / \mathrm{g}$ ), in a fluidized bed reactor (diameter: $6: 88 \mathrm{~mm}$, height: $120 \mathrm{~cm}$ ) run at superficial velocities of $0.37,0.53$ and $1.20 \mathrm{~mm} / \mathrm{s}$, corresponding to the nominal bed porosities of $0.55,0.6$ and 0.7 . Bed heights varied with the immobilized enzyme charge into the reactor, which started at $1.5 \mathrm{~g}$ (dry weight) and followed with additions of $1.5 \mathrm{~g}$ up to the maximum bed height. Reactor performance data has been obtained as conversion ( $\left(X_{a}\right)$ against normalized residence time $(\tau) / P$ total enzymatic activity $\times$ real residence time/bed liquid volume), by measuring the glucose concentration of the reactor outlet. The same kind of data was obtained by operating the reactor as a fixed bed system with downward liquid flow.

The data shows that for values of the normalized residence time greater than 900 the fluidized bed mode leads to higher conversions than the fixed bed, and that lower fluid-bed porosities are associated with higher conversions. It has been possible to achieve a conversion value of $98.5 \%$ with a real residence time of 10 minutes, while with ine conventional liquid phase process, 48 hours are needed to obtain the same conve sion. These results demonstrate the great advantage of using immobilized enzymes and the viability of usl. $\mathrm{g}$ fluidized bed reactors. 


\title{
SILAGE PROCESSING OF FORAGE BIOMASS TO ALCOHOL FUELS
}

\author{
J.C. Linden", L.L. Henk', V.G. Murphy", \\ K.D. Lange ${ }^{a}$, and R.P. Tengerdy \\ 'Department of Agricultural and Chemical Engineering \\ Colorado State University \\ Fort Collins, CO 80523 \\ bepartment of Microbiology \\ Colorado State University \\ Fort Collins, CO 80523
}

\begin{abstract}
Sweet sorghum is an attractive fermentation feedstock because forty percent of the dry weight consists of readily fermented sugars. Cellulose and hemicellulose comprise another fifty percent. If such material is to be used on a year-round basis as feedstock for ethanol production, a suitable method of storage is needed. Modified versions of ensiling are made effective by addition of cellulolytic/hemicellulolytic enzymes and lactic acid bacteria to green-chop harvested sweet sorghum prior to production of silage. In situ hydrolysis of cellulose and hemicellulose occurs concurrently with the acidic ensiling fermentation. Preliminary process designs based on laboratory and pilot scale experiments are evaluated using fixed capital equipment and production cost estimates. Energy balance analysis shows energy content of the ethanol produced to be greater than all energy requirements for sweet sorghum production, processing and product recovery.
\end{abstract}




\title{
ANALYSIS OF RENEWABLE FEEDSTOCKS FOR THE PRODUCTION OF COMMODITY CHEMICALS
}

\author{
J.K. Polman \\ Idaho National Engineering Laboratory \\ EG\&G Idaho, Inc. \\ Idaho Falls, ID 83415-2203
}

The United States has vast supplies of diverse renewable resources that are available for conversion to many different commodity chemicals. These biomass feedstocks represent an alternative to petroleum and petrochemical feedstocks that are currently used to prosuce most commodity chemicals in the U.S. Several representative biomass feedstocks were examined with respect to current issues relevant to the adoption of such feedstocks by the chemicals industry. Feedstocks included dedicated feedstock crops (such as silviculture), industrial residuals (such as potato processing residuals), and conventional food crops (such as corn). The issues that were examined included price of raw materials, degree of raw material processing necessary, storage requirements, potential fermentable sugar yield, opportunities for waste minimization, level of technology base, crop hardiness, and land usage. Based on these aspects, the representative biomass feedstocks were rated for their potential in supporting the production of commodity chemicals. The following conclusions were made: (1) the U.S. has great potential for controlling the direction of a biomass-based chemicals industry because domestic supplies of raw feedstock materials are in excess of what is required for the production of many commodity chemicals, (2) of the representative feedstocks that were analyzed, cellulosic industrial residuals and fermentable sugar-containing industrial residuals were the most promising prospects, (3) when compared to the other representative feedstocks, corn (a conventional biomass feedstock) and apple pomace (a low supply industrial residual) had many negative attributes which argued against their long term potential as feedstocks for the chemicals industry. 


\title{
REMOVAL OF CARBONYL SULFIDE AND HYDROGEN SULFIDE FROM SYNTHESIS GAS BY CHLOROBIUM THIOSULFATOPHILUM
}

\author{
R. Basu, K.T. Klasson, E.C. Clausen, and \\ J.L. Gaddy \\ University of Arkansas \\ Department of Chemical Engineering \\ Fayetteville, AR 72701
}

The anaerobic, photosynthetic bacterium Chlorobium thiosulfatophilum has been chosen from among several bacteria for its ability to convert $\mathrm{H}_{2} \mathrm{~S}$ to elemental sulfur. The bacterium utilizes $\mathrm{CO}_{2}$ as its carbon source and operates at the mesophilic temperature of $30^{\circ} \mathrm{C}$. The bacterium requires tungsten light for growth and compounds such as $\mathrm{H}_{2} \mathrm{~S}$, elemental sulfur or $\mathrm{H}_{2}$ as a source of reducing power. Of these later three compounds, $\mathrm{H}_{2} \mathrm{~S}$ as sulfide is the preferred source of reducing power, with $\mathrm{H}_{2}$ and elemental sulfur utilized only when sulfide has been depleted from the medium. The organism is also capable of indirectly utilizing COS, since $\mathrm{COS}$ reacts with water to form $\mathrm{CO}_{2}$ and $\mathrm{H}_{2} \mathrm{~S}$. This work presents kinetic information on the rate of growth of C. thiosulfatophilum, as well as the rate of uptake of both $\mathrm{H}_{2} \mathrm{~S}$ and $\mathrm{COS}$. Information on process yields and stoichiometry obtained in batch reactors is also presented. The growth on $\mathrm{CO}_{2}$ has been studied at light intensities ranging from 27-1723 lux in batch culture. Modeling results indicate that growth is dependent upon light intensity according to a Monod type relationship. 


\title{
THE REMOVAL OF VOLATILE ORGANICS IN A GAS-PHASE BIOREACTOR ${ }^{1}$
}

\author{
B.H. Davison and J.E. Thompson \\ Oak Ridge National Laboratory \\ Oak Ridge, TN $37831-6226$
}

A columnar reactor is being tested for the conversion of gaseous substrates. The microorganisms are able to remove hydrocarbons (pentane and iso-butane) from air by biological action. Bioreactor concepts that provide for interaction with gaseous substrates are being investigated. The removal of dilute hydrocarbon gases from effluent gas streams is of particular interest with the primary emphasis on n-pentane and iso-butane. Columnar bioreactors were continuously operated for over twelve months. They continue to degrade the gaseous hydrocarbons. The hydrocarbons, pentane and iso-butane, have been the sole carbon source for the microbes and the overall conversion rate has increased. Biomass levels have stabilized in this liquid-continuous configuration.

\footnotetext{
${ }^{1}$ Research sponsored by the Advanced Industrial Concepts Division-Biological and Chemical Technologes Research Program, U.S. Department of Energy, under contract DE-AC05-84OR21400, with Martin Marictta Energy Systems, Inc.
} 


\title{
CELLULASE ACTIVITY OF TRICHODERMA REESEI (Rut-C30) ON MUNICIPAL SOLID WASTE
}

\author{
A. Maxey, H. Huckabay, X.-J. Chen, and B.B. Elmore \\ Louisiana Technical University \\ Department of Chemical Engineering \\ Ruston, LA 71272
}

The increased loading of existing landfills coupled with increasingly stringent environmental constraints invites considerable investigation into alternate methods for handling municipal solid wastes.

Here a study is made of the capability of Trichoderma reesei (RUT-C30) to saccharify the cellulosic fraction of the municipal solid waste stream, thereby significantly reducing the mass loading entering the landfill while obtaining a useful intermediate (which may be deployed in a simultaneous saccharification fermentation process to obtain fuel ethanol).

Batch cultures of RUT-C 30 have shown a significantly higher enzyme activity when grown on municipal solid waste (MSW) compared to microcrystalline cellulose (Avicel). Preliminary results in batch cultures indicated an FPU of 6.08 for $2 \%(w / v)$ MSW compared to an FPU value of only 1.63 for cultures grown on $2 \%(w / v)$ Avicel. Additionally, a significant reduction in the total solids of the biodegradable fraction of the MSW is observed. 


\title{
CARBON DIOXIDE FIXATION BY MICROALGAL PHOTOSYNTHESIS USING ACTUAL FLUE GAS DISCHARGED FROM A BOILER
}

\author{
Y. Ikuta ${ }^{a}$, Y. Hukuda ${ }^{a}$, A. Hamasaki ${ }^{b}$, N. Shioji ${ }^{\text {b }}$,T. Makita ${ }^{c}$, \\ K. Hirayama ${ }^{c}, H$. Matsuzaki ${ }^{c}$, and T. Tukamoto ${ }^{c}$ \\ ${ }^{2}$ Mitsubishi Heavy Industries, Ltd. \\ Tokyo, 162 Japan \\ ${ }^{\text {bHyogo, } 676 \text { Japan }}$ \\ 'Tohoku Electric Power Co., Inc. \\ Miyagi, 980 Japan
}

To mitigate carbon dioxide emission from boilers in power plants, we are studying $\mathrm{CO}_{2}$ fixation by microalgae photosynthesis using actual flue gas since 1990 and a part of results were already presented at the 14th Symposium on Biotechnology for Fuels and Chemicals. Algae cultivation has been continued using 4 race way type cultivators, two installed in a green house and the others installed outdoors to clarify the effect of cultivating conditions such as pretreatment of make-up sea water and seasonal climate change of site on the growth of algae. To evaluate algal growth rate under the different sunshine conditions, we modified theoretical formula of algae growth rate, selected empirical constant using laboratory test results and simulated growth rate of algae for actual sunshine conditions.

The simulated results are in good agreement with test results at normal condition of growing algae. We applied this technology to find out the abnormal condition of algae growth and find out the following results: 1) Stable growth rate were sometimes interrupted by biological contaminants brought in by poorly pretreated sea water. 2) Several kinds of algae, the growth rate of which is higher than NANNP-2 were collected at neighboring sea of Tohoku district. 


\title{
BIOTECHNOLOGY OF ASSOCIATIVE NITROGEN FIXATION
}

\author{
T.G. Korzhenevskaya and M.V. Gusev \\ Department of Cell Physiology and Immunology \\ Biological Faculty \\ Moscow State University \\ 119899 Moscow, Russia
}

One of the objectives of modern tiotechnology is to prevent the environmental pollution. The use of commercial nitrogen fertilizers leads to dramatic ecological and social consequences. Alternative to industrial nitrogen fixation is biological one, the process which used solar energy, a renewable energy form. The enhance of biologically fixed nitrogen in plant nutrition could allow to avoid the pollution of environment and plants by chemical fertilizers and products of their transformation.

The major part of biological nitrogen on earth is fixed in symbioses. However only limited number of plant species form symbiotic associations with diazotrophs. Our experiments displayed the possibility to broaden the range of plants capable of associative (symbiotic) nitrogen fixation. Symbiotic associations of valuable plant species with diazotrophic cyanobacteria were obtained by cell engineering technique. Cell (tissue) cultures or protoplasts had been preliminary isolated from plants and inoculated with cyanobacteria. Subsequently the plants were regenerated from mixed cultures. The regenerated plants contained the cyanobacteria in their tissues. The compartmentalization of the host and the symbiont took place owing to formation of special structures for location of the cyanobacteria. The plants associated with diazotrophic cyanobacteria grew in the absence of combined nitrogen. Cyanobacteria isolated from natural symbioses, as compared to laboratory strains, were more effective in artificial infection of non-symbiotrophic plants. The advantages of nitrogen fixing symbiotic associations in comparison with genetic engineered objects in solving the problem of biological nitrogen fixation are discussed. The scientific prognosis of enhance of nitrogen fixation on carth while introducing new symbiotic systems to ecosystems is necessary. 


\title{
BINDING OF DISSOLVED URANTUM BY PSEUDOMONAS AERUGINOSA CSU ${ }^{1}$
}

\author{
N.D.H. Munroe , J.D. Bonner ${ }^{b}$, R. Williams', K.F. Pattison ${ }^{\text {d, }}$ \\ J.M. Norman ${ }^{b}$, and B.D. Faison ${ }^{b}$ \\ ${ }^{2}$ Florida International University \\ Miami, FL \\ bak Ridge National Laboratory \\ Oak Ridge, TN \\ 'University of Tennessee \\ Knoxville, TN \\ ${ }^{d}$ University of Pittsburgh \\ Bradford, PA
}

The mechanism of uranium binding by Fscisdomonas aeruginosa CSU, as organism under consideration for use in a biological process for treatment of uranium-contaminated effluents, was examined. Washed, resting cells were shown to remove uranium from dilute aqueous solutions of $\mathrm{UO}_{2}\left(\mathrm{NO}_{3} / 2\right.$. Loadings of $0.103 \mathrm{mg} \mathrm{U} / \mathrm{g}$ cell dry wt were achieved at equilibrium. Metal loadings were enhanced by pretreatment of the cells with polar organic solvents. Binding occurred in the absence of organic nutrients and in the presence of sodium azide. Heat-killed cells exhibited sorptive ability. Uranium binding was significantly inhibited by ferric iron [Fe(III)]. Initial binding of uranium was rapid ( $\leq 15 \mathrm{~s}$ ) and coincided with the appearance of needle-like uranium-containing structures at the cell surface. Bound uranium subsequently accumulated in the periplasmic space. Within $24 \mathrm{~h}$, all bound uranium was located intracellularly, as amorphous material. Although the cells were exposed to hexavalent uranium [U(VI)], bound material existed in the tetravalent state [U(IV)]. Fe(III) can be

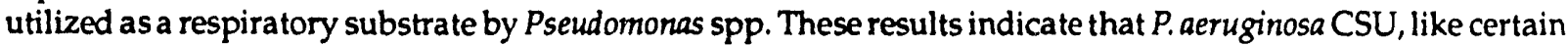
$\mathrm{Fe}$ (III)-reducers, may be capable of growth coupled with U(VI) reduction. However, this work is the first report of microbial reduction of uranium leading to intracellular deposition.

\footnotetext{
${ }^{1}$ Research sponsored by the Office of Technology Development, U.S. Department of Energy.
} 


\title{
THE EFFECT OF MEDIA COMPOSITION ON EDTA DEGRADATION BY AGROBACTERIUM RADIOBACTER
}

\author{
A.V. Palumbo, S.Y. Lee, and P. Boerman
}

\section{Environmental Sciences Division \\ Oak Ridge National Laboratory \\ Oak Ridge, TN 37831-6036}

\begin{abstract}
Complexation and consequent mobilization of radionuclides by EDTA can be a significant problem at DOE sites. In situ degradation of EDTA is an attractive option for remediation of sites containing EDTA but there is limited information on biodegradation of EDTA. The most well characterized organism that can degrade EDTA is Agrobacterium radiobacter. However, much remains to be done in defining the conditions that permit this organism to degrade EDTA. Much of the early work was done using a media containing many components that may not be necessary for EDTA degradation. We have examined the effect of various media compositions by quantifying ${ }^{14} \mathrm{C}$-labeled $\mathrm{CO}_{2}$ produced from iron- $\left[2 .{ }^{14} \mathrm{C}\right]$ EDTA and by measured loss of non-labeled EDTA by HPLC.
\end{abstract}

Interesting changes in nitrogen concentration and forms in the media result from growth under different initial conditions. With Fe-EDTA as a carbon source EDTA degradation results in a rise in $\mathrm{pH}$ and ammonia concentration. Addition of glycerol to the media results in suppression of Fe-EDTA degradation and in a decrease in $\mathrm{pH}$ and $\mathrm{NH}_{4}$ in the media. We have also found that some of the components (e.g. vitamins) of the media are not necessary for growth and biodegradation. 


\title{
POTENTLAL FOR MICROBIAL GROWTH \\ IN ARID SUBSURFACE SEDIMENTS
}

\author{
A.V. Palumbo, A. Parker, J.F. McCarthy, \\ T.J. Phelps, and J. Strong-Gunderson \\ Environmental Sciences Division \\ Oak Ridge National Laboratory \\ Oak Ridge, TN 37831-6036
}

Bioremediation at arid sites may often rely on addition of water and nutrients for stimulation of existing bacterial populations. We have examined growth of bacteria in samples from the deep subsurface at western arid sites after addition of water and nutrients to the solid material. Portions of seven samples from different depths and geological characteristics (paleosols vs. basalts) were incubated for up to $200 \mathrm{~h}$ in mineral salts medium. Growth, to a maximum of $2.1 \times 10^{6} \mathrm{cells} / \mathrm{ml}$, was observed using the microcolony enumeration method.

The amount of microbial growth arising from the solid material appeared to be related to the carbon content and the depositional history of the material. Bacteria grew in the samples with the higher carbon contents $(0.08 \%$ to $1.1 \%)$, primarily the paleosols. The three samples, primarily basalt samples, from which there was no observable growth of bacteria all had carbon contents of $0.063 \%$ or less.

These studies have indicated that there are bacterial populations in the paleosols located in the site that can respond to water and nutrient addition. These paleosols could also serve as sources of bacteria for remediation of contaminants in these layers and in adjacent basaltic layers which do not appear to have bacterial populations that respond as readily to addition of nutrients and water. 


\title{
BIOREMEDIATION OF PETROLEUM HYDROCARBONS IN SOIL COLUMN LYSIMETERS FROM KWAJALEIN ISLAND
}

\author{
T.J. Phelps ${ }^{a, b}$, R.L. Siegrist ${ }^{a}$, N.E. Korte ${ }^{a}$, D.A. Pickering ${ }^{a}$, \\ J.M. Strong-Gunderson , A.V. Palumbo a J.F. Walker ${ }^{a}$, \\ C.M. Morrissey, and R. Mackowski ${ }^{b}$ \\ anvironmental Sciences Division \\ Oak Ridge National Laboratory \\ Oak Ridge, TN 37831 \\ ${ }^{b}$ Center for Environmental Biotechnology \\ University of Tennessee \\ Knoxville, TN 37932-2567
}

Soil column studies evaluated effects of trea tments on petroleum hydrocarbon (PHC) remediation in nutrient deficient, alkaline soils of Kwajalein Atoll. Twenty-two soil columns ( $3 \mathrm{in} . \times 3 \mathrm{ft}$ ) extended from the lower vadose zone to the upper saturated zone where PHC contamination was greatest. Treatments included controls, and combinations of water, air, nutrients, and the addition of $10^{7}$ microorganisms $/ \mathrm{g}$ for each of 20 weeks (W, A, N, and $M$, respectively). Microbial colony forming units (CFU) decreased $95 \%$ in the control columns ( $\log 6.9$ to 5.6$)$ during the 7 month experiment. Trea tments without air exhibited decreased CFU while $\mathrm{W}+\mathrm{A}+\mathrm{N}$ and $\mathrm{W}+\mathrm{A}+\mathrm{N}+\mathrm{M}$ treatments exhibited increased $\mathrm{CFU}(\log 7.2$ and 7.4 respectively). $33 \%-50 \%$ of the PHC was removed by water treatments. Isotopic ratios of evolved $\mathrm{CO}_{2}$ suggested $\mathrm{PHC}$ degradation rates of $<0.5 \mathrm{mg}^{-1} \mathrm{~kg}^{-1} \mathrm{~d}$ in $\mathrm{W}+\mathrm{A}$ treatments versus $>6 \mathrm{mg} \mathrm{kg}^{-1} \mathrm{~d}^{-1}$ in $\mathrm{W}+\mathrm{A}+\mathrm{N}$. Another $30 \%-50 \%$ of the lighter PHC fractions were removed by $W+A+N$ and $W+A+N+M$ treatments. Bioaugmentation with indigenous PHC degraders did not enhance bioremediation. Although the potential for bioremediation was demonstrated by air, water, and nutrient amendments, bionemediation time could be lengthy.

"Corresponding author 


\title{
MICROBIAL BIOSORPTION OF NICKEL IN COMPLEX AQUEOUS WASTES
}

\author{
M. Reeves and L. Corder
}

Oak Ridge National Laboratory

Oak Ridge, TN 37831-6194

Nickel is a toxic metal and suspected carcinogen that is often found in aqueous wastes resulting from metal plating and finishing operations. Because of nickel's hazardous properties, wastes containing the metal are being subjected to increasingly stringent regulatory rules regarding their disposal. There is an increasing need for an efficient and cost-effective means of reducing the nickel content of such wastes to levels below regulatory concern. This study was undertaken to determine the feasibility of employing various microbial species (such as algae and bacteria) as biosorbents for the removal of nickel from aqueous wastes. Several species of algae, cyanobacteria, and bacteria were screened for their ability to biosorb ionic nickel in a surrogate waste containing a soluble nickel compound. The most promising species were then tested against actual, more chemically complex wastes, to determine their performance under these conditions. Cyanobacteria demonstrated a greater capacity for nickel biosorption than any of the other organisms tested, with two filamentous species being the best performers. Biosorption was greater, and the results more consistent, when using heat-killed cells than with live cells; this augurs well for their future deployment in a process scheme involving immobilization. Problems with competing chemical species in complex wastes may make a pretreatment step necessary before this biosorption technology can be deployed as a polishing step. 


\title{
BIOFUELS FULL FUEL CYCLE ANALYSIS
}

\author{
S.R. Bull ${ }^{\mathrm{a}}$, C.J. Riley ${ }^{\mathrm{a}}$, K.S. Tyson ${ }^{\mathrm{a}}$, and R. Costello ${ }^{\mathrm{b}}$ \\ - iational Renewable Energy Laboratory \\ Golden, CO 80401 \\ bUS. Department of Energy \\ Washingtor, DC 20585
}

The Clean Air Act Amendments (CAAA) of 1990 and the National Energy Strategy have provided motivation for the development of alternative transportation fuels as well as oxygenates for use as reformulated gasoline components. The U.S. Department of Energy has chosen ethanol from biomass as a high priority option for technology development to meet future fuel needs. To evaluate this technology choice, a study was completed to quantify the chemical and energy input and output of the ethanol from biomass fuel cycle. In the analysis, energy crops are the feedstock to produce ethanol that is used as E95 in the year 2010. The benchmark for comparison is reformulated gasoline from crude oil as defined by the CAAA. Each fuel cycle was developed as five stages; feedstock production, feedstock transport, fuel production, fuel transport, and fuel end use. The air emissions evaluated were carbon monoxide, sulfur dioxide, nitrogen oxides, volatile organic compounds, and carbon dioxide. The air emissions from $\mathrm{E} 95$ were less than or approximately equal to reformulated gascline for carbon monoxide, nitrogen oxides, and volatile organic compounds. E95 offers a major advantage in reducing sulfur dioxide and carbon dioxide. Wastewater, solid wastes, and energy requirements were also evaluated. Details of the study are presented. 


\title{
KINETIC REGULARITIES OF NON-STATIONARY BEHAVIOR OF UASB-REACTOR UNDER VARIOUS REGIMES OF FEEDING
}

\author{
V.I. Skylar", M.A. Davlyatshina", S.V. Kalyuzhnyi", \\ and S.D. Varfolomeyev \\ -Department of Chemical Enzymology \\ Chemistry Faculty \\ M.V. Lomonosov Moscow University \\ 119899 Moscow, Russia \\ ${ }^{b}$ Department of Biotechnology of Enzymes \\ Chemistry Faculty \\ Autonomous University of Coahuila \\ 25000 Saltillo, Mexicu
}

Detailed kinetic study of non-stationary behavior of UASB-reactor during transfer from one feeding regime to the other one were carried out using laboratory reactor which fed by synthetic medium. Besides usually used parameters $(\mathrm{pH}, \mathrm{COD}$, yield and content of biogas) we also determined concentrations of volatile fatty acids as well as biomass specific (acidogenic and methanogenic lacetoclastic and litotrophic)) activities in 6 equidistant sampling ports along reactor height. Experiments were carried out under stepwise increasing of organic load from 3.4 up to $45.1 \mathrm{~g} C O D / L$ react. day.

The general regularities of establishing of quasi-steady-state of operation performance of UASB-reactor were similar for all transfers to new feeding regime. Initially some disturbances (appearance of large gas bubble in the sludge bed zone, partial colmatation, destruction of granules) were induced in reactor under transfer to new feeding regime. They were practically diminished after replacing of 36 reactor volume of medium but COD removal efficiency in effluent was not higher than $60-70 \%$. The stable operational performances of UASB-reactor as well as $98-99.6 \%$ COD removal efficiency in effluent were achieved after replacement else 10-12 volume of medium.

Investigation of stratification of biomass specific activities along reactor height showed that they were diminished under increasing reactor height in sludge bed zone. However the values of all biomass specific activities were increased (in twice-three time and higher) in sludge blanket zone controversy to decreasing of concentration of volatile suspended solids. Gas-lifting of microgranules of most active biomass from the sludge bed zone to the sludge blanket zone may be a reason of this effort.

Above described data as well as data on determination of number of cells of basic microbial groups will be used by us for the development of mathematical model of operation performance of UASB-reactor. 


\title{
DIFFERENTIAL BIOAVAILABILITY OF DEEP SUBSURFACE NATURAL ORGANIC MATTER TO MICROBIAL ISOLATES: IMPLICATIONS TO IN SITU BIOREMEDIATION
}

\author{
J.M. Strong-Gunderson, A.V. Palumbo, J. McCarthy, \\ S. Scarborough, and T. Mehlhom \\ Environmental Sciences Division \\ Oak Ridge National Laboratory \\ Oak Ridge, TN 37831-6038
}

Recalcitrant natural organic matter (NOM) (humic/fulvic material) may contain structures (multiple rings) similas to contaminants. Thus, bacteria capable of metabolizing these types of compounds may be useful in bioremediation.

To effectively examine the capacity of deep subsurface bacteria to assimilate NOM, and their interactions with inorganic nutrients we developed a method that relies on 96-well microtiter plates. Microbial growth is measured by increases in optical density and we can determine the bioavailability of $>5$ different water fractions and $>20$ isolates/day. A bioavailability comparison was made from ground water and bacteria collect at Deep Subsurface Microbiology sites - Savannah River Laboratory, Idaho National Engineering Laboratory and Hanford.

Among the isolates tested, NOM from Hanford (well DB11) was the most bioavailable regardless of the bacteria tested. DB11 is substantially different in groundwater chemistry from other wells tested. Reconstructed consortia demonstrated significant microbial growth over individual isolates.

Isolates tested to date have shown variable capabilities for utilizing recalcitrant NOM. Further testing of bacteria with broad or unique metabolic capabilities from these and other sites is planned as well as characterizing the NOM. Information from these experiments will yield insight into the requirements needed for increasing microbial growth for the bioremediation of hazardous waste sites. 


\title{
PORPHYRIN-CATALYZED REDUCTION OF NITROAROMATICS FOR THE TREATMENT OF MUNITIONS WASTES
}

\author{
J.-G. Cho and K.L. Sublette* \\ Center for Environmental Research \& Technology \\ University of Tulsa \\ Tulsa, OK 74104
}

Porphyrins are tetrapyrolle ring structures which are metal chelating and often found in the active sites of enzymes involved in redox reactions. We have demonstrated that porphyrins alone may act as mediators in the transfer of electrons to or from various functional groups under a range of reaction conditions. One such application is the porphyrin-catalyzed reduction of nitroaromatics to the corresponding amines. If the nitroaromatics are components of munition wastes, porphyrin pretreatment can render the wastes safer to handle and more amenable to biotreatment.

Porphyrin-catalyzed reduction of nitroaromatics to corresponding amino-substituted products has been demonstrated in both batch and continuous reactors. Intermediate and final products of porphyrin-catalyzed reduction of mono-, di-, and trinitrotoluenes were identified and a pathway for the reduction of the nitro group to the corresponding amino group proposed. The catalytic activity of porphyrin was confirmed by UV/VIS absorption spectra and basic kinetics of porphyrin-catalyzed reduction were investigated. The porphyrincatalyzed reduction of mononitrotoluenes was found to be first order over a concentration range of $0-0.15 \mathrm{mH}$ at $\mathrm{pH} 9.0$ (optimum). First order rate constants for 2-nitrotoluene and 4-nitrotoluene reduction by dithiothreitol catalyzed by $\mathrm{Co}^{+3}$-centered hematoporphyrin were also determined. Of several reductants tested, dithiothreitol, sodium dithionite, and sodium sulfide were seen to give significant reduction of nitrobodies. Cobalt (III) and iron (III) iorıs were also compared as the chelated metal ion in the reduction of 2-nitrotoluene.

A continuous process utilizing $\mathrm{Co}^{+3}$-centered deuteroporphyrin $\mathrm{IX}, 2,4$-disulfonic acid immobilized on DEAE-substituted glass beads in an upflow packed-bed reactor has also been evaluated.

"Corresponding author. 


\title{
LARGE-SCALE PRODUCTION OF THIOBACILLUS DENITRIFICANS BIOMASS TO SUPPORT PILOT AND FIELD TESTS OF MICROBIAL SULFIDE OXIDATION
}

\author{
S. Hasan, B. Rajganesh, and K.L. Sublette* \\ Center for Environmental Research \& Technology \\ University of Tulsa \\ Tulsa, OK 74104
}

Thiobacillus denitrificans is an obligate autotroph and facultative anaerobe which can utilize reduced sulfur compounds as energy sources with oxidation to give sulfate. Under anoxic conditions nitrate can be used as a terminal electron acceptor with reduction to elemental nitrogen. It has been shown that $T$. denitrificans may be readily cultured on $\mathrm{H}_{2} \mathrm{~S}(\mathrm{~g})$ or aqueous inorganic sulfide aerobically and anoxically in batch and continuous reactors under sulfide-limiting conditions. A microbial process for the removal of $\mathrm{H}_{2} \mathrm{~S}$ from gases and sulfides from sulfide-laden (sour) water has been proposed based on contact of the sour gas or sour water with a culture of a sulfide-tolerant strain of $T$. denitrificans.

The many applications of this technology require an economical means of growing and harvesting the biomass. It has been shown that $T$. denitrificans may be flocculated by co-culture with floc-forming heterotrophs to produce sulfide-active floc with excellent settling properties. We have now shown that once flocculated these cultures can be repeatedly sub-cultured without lost of flocculation.

This paper describes the economics and practical aspects of growth of $T$. denitrificans at the 1000 gal scale in a stirred tank. Cells were harvested by gravity sedimentation in a conical-bottom tank. Biomass yields, growth rates and culturing costs are presented.

"Corresponding author. 


\title{
A NEW BIOMATERIAL TO ELIMINATE HEAVY METAL IONS FROM THEIR DILUTE WASTE SOLUTIONS
}

\author{
K. Suyama $a^{a}$, Y. Fukazawa ${ }^{a}$, and Y. Umetsu ${ }^{b}$ \\ ababoratory of Molecular Technology of Animal Products \\ Faculty of Agriculture \\ Tohoku University \\ Sendai, Japan \\ ${ }^{b}$ Institute for Advanced Materials Processing \\ Tohoku University \\ Sendai, Japan
}

The hen eggshell membrane (ESM) is an intricate lattice network of fibers with high surface area and is suggested to be the part where calcium deposition takes place. Although the precise role of ESM mineralization is not clear, the insoluble protein would appear to be essential for mineralization to occur. We found ESM protein eliminated various heavy metal ions from their dilute aqueous solutions in high yield and in short contact time but depending on $\mathrm{pH}$ and characteristics of the individual ions. Eggshell membrane was collected after immersion of the eggshell in $5 \% \mathrm{HC} 1$ for over night followed by rinsing with distilled water. Metal ions were determined by ICP AES or colorimetry. Metal ions complex formation with ESM iested were shown as follow.

1. Common metals: $\mathrm{NA}^{+} \mathrm{K}^{+}, \mathrm{Cu}^{2+}, \mathrm{Ni}^{2+}, \mathrm{Zn}^{2+}, \mathrm{Fe}^{2+}, \mathrm{Fe}^{3+}$, and others

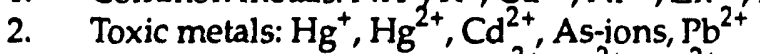

3. Actinides and Lantanides: $\mathrm{U}^{3+}, \mathrm{La}^{2+}, \mathrm{Nd}^{2+}, \mathrm{Pr}^{2+}, \mathrm{Gd}^{2+}, \mathrm{Ce}^{2+}, \mathrm{Sm}^{2+}, \mathrm{Eu}^{2+}$

4. Precious elements: $\mathrm{Au}, \mathrm{Pd}, \mathrm{Pt}, \mathrm{Ag}^{+}$.

The ion-loading capacities of ESM were ranging from 13 to over $200 \mathrm{mg} / \mathrm{g}$ ESM for most ions considered here and particularly high for $\mathrm{Pt}, \mathrm{Pd}$, and $\mathrm{Au}$. 


\title{
A NEW WAY OF INVESTIGATION FOR THE CONTROL OF SLURRY ODOURS
}

\author{
P. Antoine ${ }^{a}$, J. Godefroida, P. Anselme, \\ M.-P. De Poorter ${ }^{b}, M$. Vande Woestyne ${ }^{b}$, \\ P. Rolleghem ${ }^{b}, W$. Verstraete ${ }^{b}$ and P. Thonart ${ }^{a}$ \\ ${ }^{a}$ Centre Wallon de Biologie Industrielle Faculté Agronomique \\ Passage des Déportés, 2 B-5030 Gembloux, Belgium \\ ${ }^{b}$ Laboratorium voor Mikrobiele Ekologie \\ 653 B-9000 Gent, Belgium
}

In Europa and especially in Belgium, laws and modern methods of breeding lead farmers to keep slurry for long periods. During stockage, manure undergoes many physical and chemical transformations.

The use of slurry for land spreading presents three kinds of problems:

1) A more or less important thickening,

2) The maturation in anaerobic conditions produces some undesirable compounds,

3) The spreading of large amounts of slurry on the soil is dangerous for the environment because of the potential risks of eutrophication and accumulation of minerals in soil.

After having developed a starter which helps to avoid the formation of crusts and sediments, we study the metabolism of different compounds which are supposed to be involved in odours (volatile fatty acids, phenols, indols, benzoic acid and derivatives). We follow their metabolic pathways when amino acids and other precursors are added to slurries.

Our work shows that one of the most important sources of variation comes from the variability of the substrate; the chemical and microbiological composition dictates the metabolic pathways and consequently, the olfactometric parameters of the product. The control of the biomass activity by use of repressors and microbiological starters may help us to modify them.

This work was supported by IRSIA-IWONL. 


\title{
MODELING AND OFTIMIZATION OF FED-BATCH BIOREACTORS FOR TREATMENT OF TOXIC CHEMICALS USING NEURAL NETWORKS
}

\author{
Q. Chen and W.A. Weigand \\ University of Maryland at College Park \\ Department of Chemical Engineering \\ College Park, MD 20742
}

One conventional reactor scheme for waste treatment consists of a stirred tank with cell recycle. However, if the desired effluent concentration is very low, very large reactors will be required. An alternative to this arrangement would be a set of sequenced batch or fed-batch bioreactors. In particular, if there is strong substrate inhibition, which is common for many toxic chemicals, fed-batch reactors will provide a much shorter reaction time. One approach to determine the feeding profile which minimizes the reaction time is to use some optimization scheme, e.g., the maximum principal. However, this type of optimization scheme is very sensitive to model accuracy. A first principal kinetic model which has the accuracy required for optimization purposes for this type of nonlinear process can be very difficult to determine. Our approach is to model the process using neural network techniques. In addition, we have developed an approach to develop both the optimal feeding profiles and a control scheme using the network model. The method is illustrated for two different toxic compounds, methanol and thiodyglycol. 


\title{
REDUCTION OF CARBON DIOXIDE ACCUMULATION BY USE OF ALTERNATIVE FUELS FROM BIOMASS
}

\author{
C.E. Wyman \\ Alternative Fuels Division \\ National Renewable Energy Laboratory \\ Golden, CO 80401
}

Substitution of biofuels derived from lignocellulosic biomass for conventional fuels would reduce the accumulation of carbon dioxide in the atmosphere and the possibility of global climate change, while also improving our energy security and trade deficit, revitalizing rural and farm economies, and addressing urban air pollution and waste disposal problems. The major fractions of biomass, cellulose and hemicellulose, can be broken down into sugars that can be fermented into ethanol. Biomass can also be gasified to a mixture of carbon monoxide and hydrogen for catalytic conversion into methanol. Algae could consume carbon dioxide from power plants and produce lipid oil that can be converted into a diesel fuel substitute. Through anaerobic digestion, a consortium of bacteria can break down cellulosic biomass to generate a medium-Btu gas that can be cleaned up for pipeline-quality methane. Catalytic processing of pyrolytic oils from biomass produces a mixture of olefins that can be reacted with alcohols to form ethers such as methyl tertiary butyl ether (MTBE) for use in reformulated gasoline to reduce emissions. Each of these technologies is briefly described. The costs have been reduced significantly for biofuels, and the potential exists to be competitive with conventional fuels. An analysis of energy flows is presented for an example of these technologies, and a carbon dioxide balance provided for fossil fuels used. This analysis includes consideration of the fuel utilization and assignment of carbon dioxide to coproducts. Because biofuels technologies require little if any fossil fuel inputs, carbon is recycled through their use, reducing substantially the net amount of carbon dioxide released to the atmosphere. 

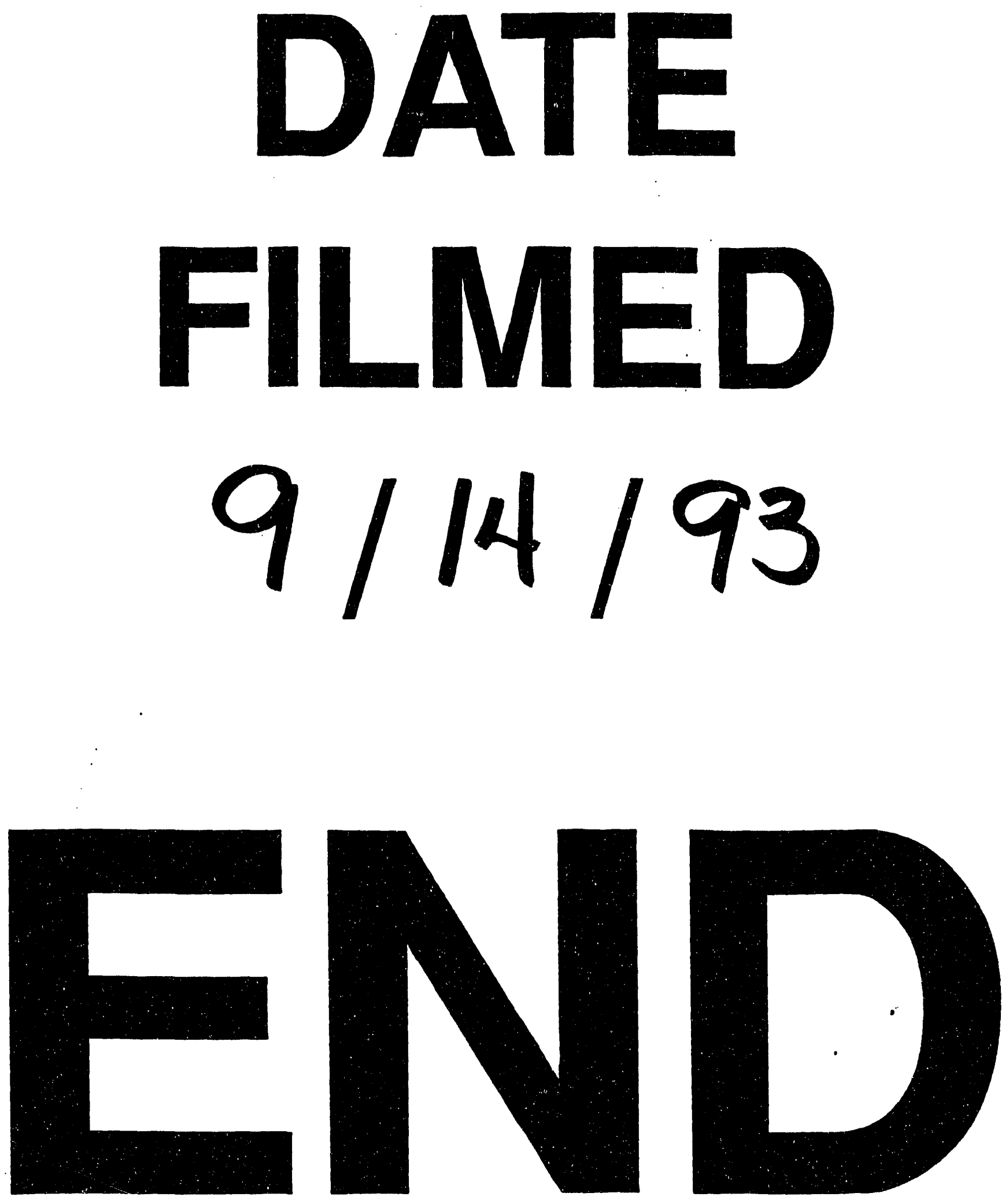
